\title{
Subsurface mapping and reservoir analysis of the Upper Devonian Venango and Bradford groups in Westmoreland County, Pennsylvania
}

\author{
Michael F. Coughlin
}

West Virginia University

Follow this and additional works at: https://researchrepository.wvu.edu/etd

\section{Recommended Citation}

Coughlin, Michael F., "Subsurface mapping and reservoir analysis of the Upper Devonian Venango and Bradford groups in Westmoreland County, Pennsylvania" (2009). Graduate Theses, Dissertations, and Problem Reports. 4452.

https://researchrepository.wvu.edu/etd/4452

This Thesis is protected by copyright and/or related rights. It has been brought to you by the The Research Repository @ WVU with permission from the rights-holder(s). You are free to use this Thesis in any way that is permitted by the copyright and related rights legislation that applies to your use. For other uses you must obtain permission from the rights-holder(s) directly, unless additional rights are indicated by a Creative Commons license in the record and/ or on the work itself. This Thesis has been accepted for inclusion in WVU Graduate Theses, Dissertations, and Problem Reports collection by an authorized administrator of The Research Repository @ WVU. For more information, please contact researchrepository@mail.wvu.edu. 


\title{
Subsurface Mapping and Reservoir Analysis of the Upper Devonian Venango and Bradford Groups in Westmoreland County, Pennsylvania
}

\author{
Michael F. Coughlin \\ Thesis submitted to the \\ Eberly College of Arts and Sciences \\ at West Virginia University \\ in partial fulfillment of the requirements \\ for the degree of
}

Master of Science

in Geology

Tim Carr, Ph.D., Chair

Richard Smosna, Ph.D.

Patrick McBride, M.S.

Department of Geology and Geography

Morgantown, West Virginia

2009

Keywords: Fifth, Bayard, Speechley Stray, Speechley, Balltown B, Venango Group, Bradford Group, Southwestern Pennsylvania, Upper Devonian, Appalachian Basin 


\author{
ABSTRACT \\ Subsurface Mapping and Reservoir Analysis of the Upper Devonian Venango and \\ Bradford Groups in Westmoreland County, Pennsylvania \\ Michael F. Coughlin
}

The Upper Devonian Bradford and Venango groups of southwest Pennsylvania are the principal reservoirs in Westmoreland County. These reservoirs were deposited in several fluvial-deltaic environments as part of the "Catskill delta complex". Although these sandstone units have been actively drilled for many years, uncertainties remain in depositional environments, stratigraphic identification, and correlation in the subsurface. Approximately 135 geophysical logs were correlated, and subsurface maps were generated for the reservoirs. The reservoir units of interest include the Fifth, Bayard, Speechley Stray, Speechley, and Balltown B. By linking geologic parameters to reservoir quality and production, the analysis has provided a better understanding of the reservoirs within the study area. Log analysis and cross plot techniques provided mineral composition changes across the study area. Mineralogical compositions were used to interpret depositional environment. High production rates coincide with thick sandstone lobes and lithology, and are not structurally influenced. It appears that the quartz-rich fluvial-deltaic rocks are the best targets as opposed to carbonate dominated marine rocks. The lower Speechley sequence has the highest potential for natural gas productivity. The lower Speechley sequence was interpreted as a valley-fill estuarine sandstone. The sandstone is vertically and laterally extensive with low water saturation. The Speechley Stray sandstone should also be targeted for natural gas. The lower Speechley sequence was interpreted as a muddy delta front deposited along a shoreline. This sandstone was selected because of the potential for high secondary porosity caused by dissolution of calcite. 


\section{ACKNOWLEDGEMENTS}

First and foremost, I would like to thank the members of my committee for all the guidance and advice that made the completion of this project possible. I would like to thank Dr. Carr specifically for his patience, understanding, and consistently calm demeanor given the short amount of time provided for such a large project. I thank Dr. Smosna for his availability and advice on issues of thesis protocol and his willingness to answer any question. I would like to thank Dr. Carr and Dr. Smosna for being sources of motivation during some of the more stressful moments in this process. I thank Patrick McBride for the enormous amount of advice and support provided as a professional and a friend.

I would also like to thank Roy Lynch and Rick Goings from Dominion Exploration \& Production, Inc. for making this project possible through access to data. I would also like to thank Roy Lynch for his invaluable career advice when I was an intern under his supervision. 


\section{TABLE OF CONTENTS}

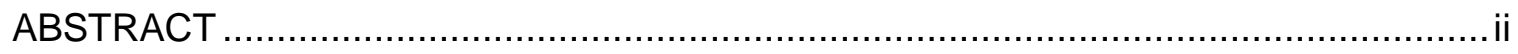

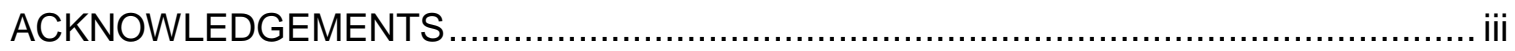

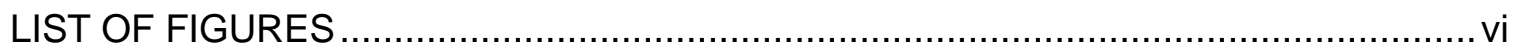

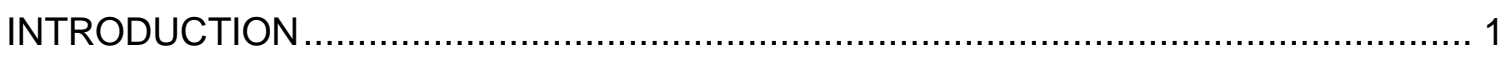

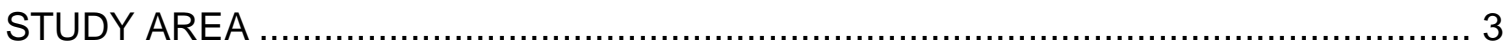

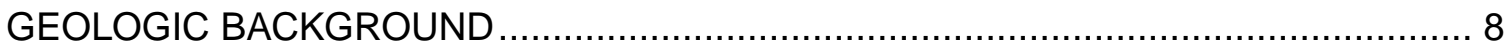

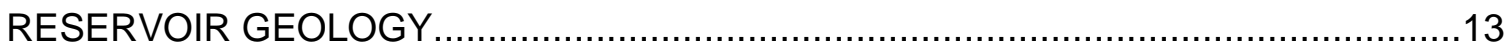

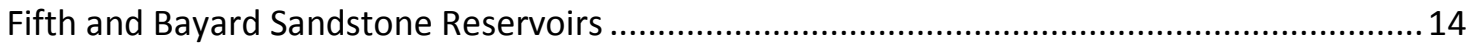

Speechley Stray, Speechley, and Balltown B Sandstone Reservoirs....................................... 15

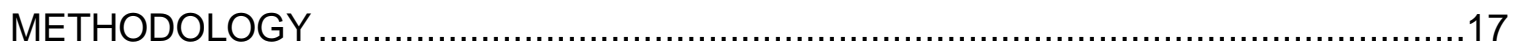

DESCRIPTION AND INTERPRETATION OF THE BRADFORD GROUP SANDSTONE

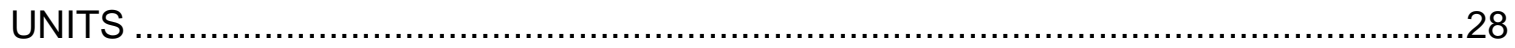

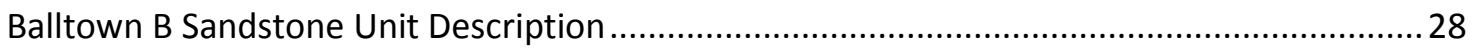

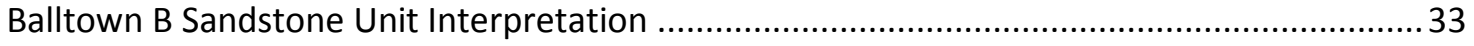

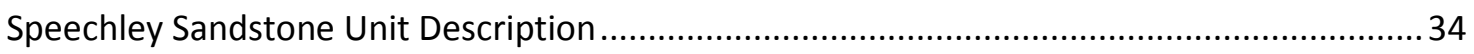

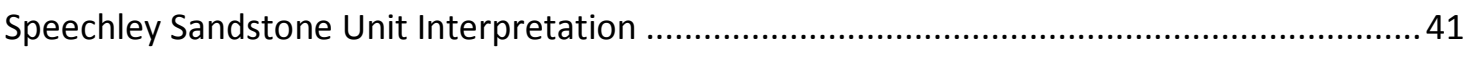

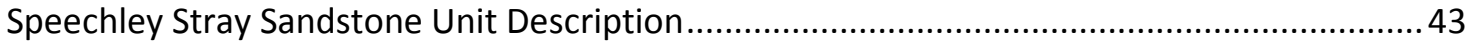

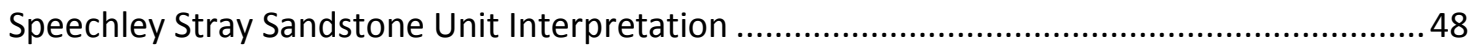

DESCRIPTION AND INTERPRETATION OF THE VENANGO GROUP SANDSTONE

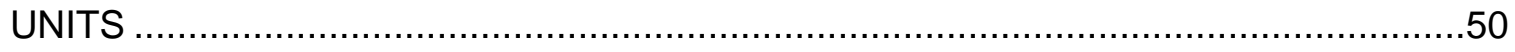

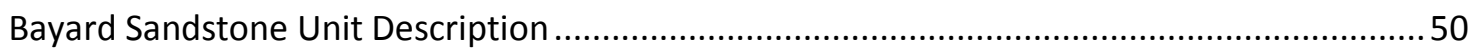

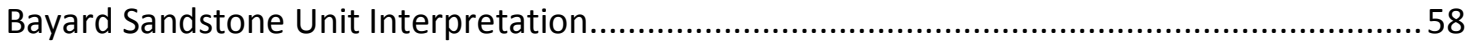

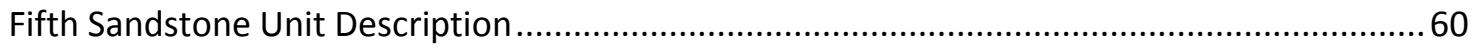

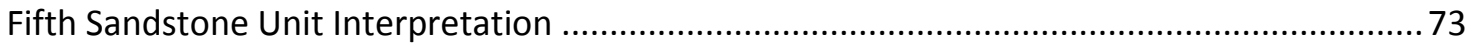

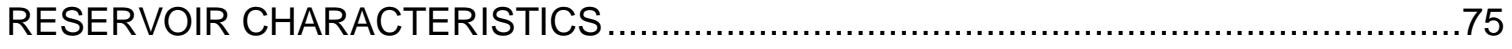

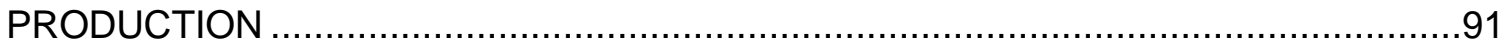

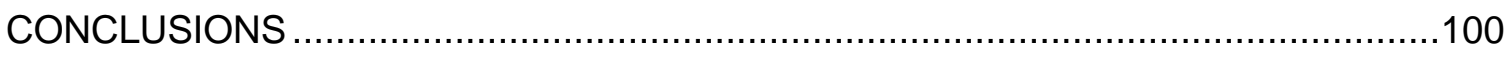


REFERENCES. 


\section{LIST OF FIGURES}

Figure 1. Study area, Westmoreland County, Pennsylvania (modified from McDaniel, 2006).

Figure 2. Westmoreland County, Pennsylvania base map. The red lines trending northeast-southwest indicate anticlinal hinge traces (modified from McDaniel, 2006).... 5

Figure 3. Study area subsurface (subsea) structure map for the top of the Fifth sandstone. Red indicates structural highs and blue indicates structural lows. Contour

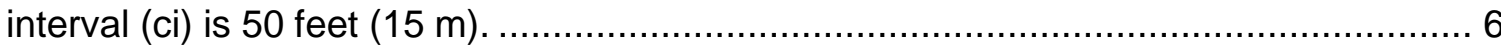

Figure 4. Stratigraphy of the Upper Devonian in study area. Formal lithostratigraphic terminology shown in bold. Commonly used drillers' terminology shown in italics. Studied units are highlighted (modified from Patchen et al., 1997). 7

Figure 5. Late Devonian paleogeography during the Acadian orogeny (modified from Ettensohn, 1985).

Figure 6. Upper Devonian foreland ramp depositional model ( from Castle, 2000). .......10

Figure 7. Upper Devonian Catskill complex delta systems prograding westward (from Boswell and Jewell, 1988).

Figure 8. Image 1 shows shallow-sloped basin during deposition of the Venango Group. Image 2 shows sloped basin during Bradford Group deposition (modified from Boswell and Donaldson, 1988).

Figure 9. Digital geophysical type log (API \#3712925989). Gamma ray, resistivity, photo electric, density and porosity curves are located in tracks one, two, three and four respectively. Crossover of the density and neutron porosity logs is highlighted in red and indicates gas-rich intervals. Location of type log well is shown in Figure 2.

Figure 11. Base map showing location of cross section grid. See figure 2 for location of base map.

Figure 12. Archie Equation for determining water saturation from porosity and resistivity (modified from Asquith and Krygowski, 2004).

Figure 13. RHOmaa-Umaa derived compositions plotted with mineralogy derived from XRD analysis of a sidewall at the top of the Speechley sandstone unit (subsea depth of 2935 to -2945 feet). RHOmaa-Umaa determined mineralogy compares favorably with the mineralogy determined by XRD analysis.

Figure 14. RHOmaa-Umaa derived mineralogical compositions for four nearby wells plotted with core mineralogical compositions derived from thin section analysis (LaSota, 1988 ) in the Sportsman core for the basal Fifth sandstone unit (subsea depth of -2120 to -2125 feet). 27

Figure 15. Gamma ray log signature that characterizes the Balltown B sandstone unit. 29 
Figure 16. Balltown B net sandstone map. Orange area indicates thick sandstone sections decreasing to the white areas indicating thinner sandstone sections. Cross section A-A' shown in Figure 17.

Figure 17. Stratigraphic cross section of the Balltown B sandstone. The datum is the top of the Balltown $B$ unit. Blue shading highlights where the API value is less than a hundred. The Balltown $B$ sandstone unit thins to the north and south.

Figure 18. Balltown B sandstone Umaa map. Cool colors indicate low Umaa values suggesting quartz-rich rocks and warmer colors indicate higher Umaa values suggesting increased calcite or clay content.

Figure 19. Gamma ray log signature that characterizes the Speechley sandstone unit. 35 Figure 20. Net sandstone map of the lower Speechley sequence. Orange area indicates thick sandstone sections decreasing to the white areas indicating thinner sandstone sections. Cross section A-A' shown in Figure 22.

Figure 21. Net sandstone map of the upper Speechley sequence. Orange area indicates thick sandstone sections decreasing to the white areas indicating thinner sandstone sections. Cross section A-A' shown in Figure 22.

Figure 22. Stratigraphic cross section of the Speechley sandstone. The datum is the top of the Speechley unit. Pink shading highlights the lower sequence with API values less than a hundred. Green shading highlights the upper sequence with API values less than a hundred.

Figure 23. Umaa map of the lower Speechley sequence. Cool colors indicate low Umaa values suggesting quartz-rich rocks and warmer colors indicate higher Umaa values suggesting increased calcite or clay content.

Figure 24. Umaa map of the upper Speechley sequence. Cool colors indicate low Umaa values suggesting quartz-rich rocks and warmer colors indicate higher Umaa values suggesting increased calcite or clay content.

Figure 25. Distribution of facies in a transgressive estuary (modified from Dalrymple and others, 1992).

Figure 26. Gamma ray log signature that characterizes the Speechley Stray sandstone unit.

Figure 27. Speechley Stray net sandstone map. Orange area indicates thick sandstone sections decreasing to the white areas indicating thinner sandstone sections. Cross section A-A' shown in Figure 29.

Figure 28. Speechley Stray Umaa map. Cool colors indicate low Umaa values suggesting quartz-rich rocks and warmer colors indicate higher Umaa values suggesting increased calcite or clay content.

Figure 29. Stratigraphic cross section of the Speechley Stray sandstone. The datum is the top of the Speechley Stray unit. Blue shading highlights where the API value is less than a hundred. 
Figure 30. A parasequence deposited on a muddy siliciclastic shoreline with upward thinning bedsets and shallowing upward (modified from Holland, 2008).

Figure 31. Gamma ray log signature that characterizes the Bayard sandstone unit......52

Figure 32. Bayard lower sequence net sandstone map. Orange area indicates thick sandstone sections decreasing to the white areas indicating thinner sandstone sections. Cross section A-A' shown in Figure 34.

Figure 33. Bayard upper sequence net sandstone map. Orange area indicates thick sandstone sections decreasing to the white areas indicating thinner sandstone sections. Cross section A-A' shown in Figure 34.

Figure 34. Stratigraphic cross section of the Bayard sandstone. The datum is the top of the Bayard unit. Purple shading highlights the lower sequence with API values less than a hundred. Green shading highlights the upper sequence with API values less than a hundred.

Figure 35. Bayard lower sequence Umaa map. Cool colors indicate low Umaa values suggesting quartz-rich rocks and warmer colors indicate higher Umaa values suggesting increased calcite or clay content.

Figure 36. Bayard upper sequence Umaa map. Cool colors indicate low Umaa values suggesting quartz-rich rocks and warmer colors indicate higher Umaa values suggesting increased calcite or clay content.

Figure 37. Gamma ray log signature that characterizes the Fifth sandstone unit.

Figure 38. Fifth sandstone sequence one net sandstone map. Orange area indicates thick sandstone sections decreasing to the white areas indicating thinner sandstone sections. Cross section A-A' shown in Figure 42.

Figure 39. Fifth sandstone sequence two net sandstone map. Orange area indicates thick sandstone sections decreasing to the white areas indicating thinner sandstone sections. Cross section A-A' shown in Figure 42.

Figure 40. Fifth sandstone sequence three net sandstone map. Orange area indicates thick sandstone sections decreasing to the white areas indicating thinner sandstone sections. Cross section A-A' shown in Figure 42.

Figure 41. Fifth sandstone sequence four net sandstone map. Orange area indicates thick sandstone sections decreasing to the white areas indicating thinner sandstone sections. Cross section A-A' shown in Figure 42.

Figure 42. Stratigraphic cross section of the Fifth sandstone. The datum is the top of the Fifth sandstone unit. Blue shading highlights sequence one, orange shading highlights sequence two, green shading highlights sequence three, red shading highlights sequence four.

Figure 43. Fifth sandstone sequence one Umaa map. Cool colors indicate low Umaa values suggesting quartz-rich rocks and warmer colors indicate higher Umaa values suggesting increased calcite or clay content. 
Figure 44. Fifth sandstone sequence two Umaa map. Cool colors indicate low Umaa values suggesting quartz-rich rocks and warmer colors indicate higher Umaa values suggesting increased calcite content.

Figure 45. Fifth sandstone sequence three Umaa map. Cool colors indicate low Umaa values suggesting quartz-rich rocks and warmer colors indicate higher Umaa values suggesting increased calcite content.

Figure 46. Fifth sandstone sequence four Umaa map. Cool colors indicate low Umaa values suggesting quartz-rich rocks and warmer colors indicate higher Umaa values suggesting increased calcite content.

Figure 47. Balltown B unit degree of crossover map. Pink indicates cross over effect caused by the presence of hydrocarbons; blue indicates a lack of hydrocarbons. .77

Figure 48. Balltown B unit water saturation map. Blue indicates a high percentage of water, white indicates a low percentage of water.

Figure 49. Speechley degree of crossover map. Pink indicates cross over effect caused by the presence of hydrocarbons; blue indicates a lack of hydrocarbons. 80

Figure 50. Speechley water saturation map. Blue indicates a high percentage of water, white indicates a low percentage of water.

Figure 51. Speechley Stray degree of crossover map. Pink indicates cross over effect caused by the presence of hydrocarbons; blue indicates a lack of hydrocarbons. .83

Figure 52. Speechley Stray water saturation map. Blue indicates a high percentage of water, white indicates a low percentage of water.

Figure 53. Bayard degree of crossover map. Pink indicates cross over effect caused by the presence of hydrocarbons; blue indicates a lack of hydrocarbons.

Figure 54. Bayard water saturation map. Blue indicates a high percentage of water, white indicates a low percentage of water.

Figure 55. Fifth sandstone degree of crossover map. Pink indicates cross over effect caused by the presence of hydrocarbons; blue indicates a lack of hydrocarbons.

Figure 56. Fifth sandstone water saturation map. Blue indicates a high percentage of water, white indicates a low percentage of water.

Figure 57. Isomap of commingled gas open flow production rates. Primary contour intervals are spaced at 200 thousand cubic feet of gas per day. Blue and green indicate low production rates; pink and red indicate high production rates.

Figure 58. Production bubble map of commingled gas open flow production rates. Small circles with cool colors indicate lower production rates. Large circles with hot colors indicate higher production rates.

Figure 59. Production bubble map of commingled gas open flow production rates combined with the net sandstone map of the Balltown B. Small circles with cool colors indicate low production rates (see Figure 58 for production scale). Large circles with hot 
colors indicate high production rates. Orange shading indicates thick sandstone sections decreasing to the white areas indicating thinner sandstone sections.

Figure 60. Production bubble map of commingled gas open flow production rates combined with the net sandstone map of the lower Speechley sequence. Small circles with cool colors indicate low production rates (see Figure 58 for production scale). Large circles with hot colors indicate high production rates. Orange shading indicates thick sandstone sections decreasing to the white areas indicating thinner sandstone sections.

Figure 61. Production bubble map of commingled gas open flow production rates combined with the net sandstone map of the Speechley Stray. Small circles with cool colors indicate low production rates (see Figure 58 for production scale). Large circles with hot colors indicate high production rates. Orange shading indicates thick sandstone sections decreasing to the white areas indicating thinner sandstone sections.

Figure 62. Production bubble map of commingled gas open flow production rates combined with the net sandstone map of the Fifth sandstone sequence one. Small circles with cool colors indicate low production rates (see Figure 58 for production scale). Large circles with hot colors indicate high production rates. Orange shading indicates thick sandstone sections decreasing to the white areas indicating thinner sandstone sections. 


\section{INTRODUCTION}

The Upper Devonian Bradford and Venango sandstone units are major reservoirs in Westmoreland County, in southwest Pennsylvania. In the Appalachian basin, these units have been the focus of oil and gas exploration for over a hundred years. Drilled in 1859, the Drake well targeted the shallow sandstone units of the Venango Group, and was the first major economically successful oil well in the Appalachian basin. Initial oil production was only 2,000 bbl (barrels) of oil in the first year, but the Drake well was significant enough to attract drillers from distant regions (Harper et al., 1999). The Bradford and Venango sandstone units are the nation's oldest and most exploited reservoirs, and to date, have produced ninety percent of Pennsylvania's natural gas (Harper and Laughrey, 1987).

Because the Bradford and Venango sandstone units rarely outcrop in southwest Pennsylvania, the majority of information originates from subsurface data. Previous subsurface studies have established the regional stratigraphic framework (Kelley and Wagner, 1972; Piotrowski and Harper, 1979; Boswell and Jewell, 1988; Hopkins, 1988; Harper and Laughrey, 1989); however, uncertainties concerning stratigraphy and depositional environment remain. Due to the lenticular nature and frequent vertical repetition observed in many of the sandstone units, subsurface correlations of the Bradford and Venango sandstone units are notoriously difficult in southwest Pennsylvania (Hopkins, 1988). This study involves a more thorough and contemporary analysis of subsurface and reservoir data in order to enhance our understanding of the Bradford and Venango reservoir units. 
Across the study area, geophysical well logs, cuttings, core data, and production data were analyzed. Focus was placed on multiple sandstone reservoirs including the Fifth Sand and Bayard units of the Venango Group; and the Speechley Stray, Speechley, and Balltown B units of the Bradford Group. Specific objectives of this study included:

(1) creation of detailed cross sections and reservoir maps,

(2) identification of reservoir geometry and trends,

(3) interpretation of depositional environments,

(4) linking geologic attributes to reservoir quality and production, and

(5) identification of possible new exploration and development targets.

As production continues in the Appalachian basin, competition for known acreage and the frequency of dry holes will decrease profits. Continued advancements in reservoir analysis are crucial to effectively enhance profitability. From an economic standpoint this study provides further insight into Upper Devonian sandstone reservoirs, and aids in future production in southwest Pennsylvania. 


\section{STUDY AREA}

The study area encompasses approximately 150 square miles (390 square km) within Westmoreland County, Pennsylvania (Figure 1). Westmoreland County is located in the shallow natural gas belt of the Appalachian basin, where drilling depths typically do not exceed 5000 feet $(1525 \mathrm{~m})$. The study area is within the Appalachian plateau province, which is adjacent to the structural front of the Appalachian Mountains. The overall structural setting is characterized by northeast-southwest trending anticlines that decrease in amplitude from east to west (Boswell, et al., 1988). The well locations trend northeast along the anticlines (Figure 2). In the subsurface of the study area, there are two prominent anticlines which are expressed by surface structures. These structures are relatively simple consisting of broad and gently dipping folds (Figure 3). The Grapeville anticline lies to the west and the Fayette anticline lies to the east.

This area was selected primarily due to the adequate well control. Within the study area, well spacing varies, but most wells are located within 3000 feet $(915 \mathrm{~m})$ of adjacent wells. The study area provides an abundance of geophysical logs, established type logs, core data, and a long history of production data.

Across the study area of southwest Pennylvania, the Upper Devonian sandstone units are divided into four major sequences known as the Braillier Formation, Elk Group, Bradford Group, and Venango Group from bottom to top (Ryder, 1995). For this study, the Bradford and Venango groups were the focus and can be broken down into fifteen to twenty informal driller sandstone units separated by shale and siltstone rich intervals (Hopkins, 1988). The driller units that will be the focus for this study include the Fifth and Bayard of the Venango Group and the Speechley Stray, Speechley, and Balltown B of the Bradford Group (Figure 4). These sandstone units were the focus of the study, 
because they are the best natural gas producing intervals within the study area and have abundant subsurface data.

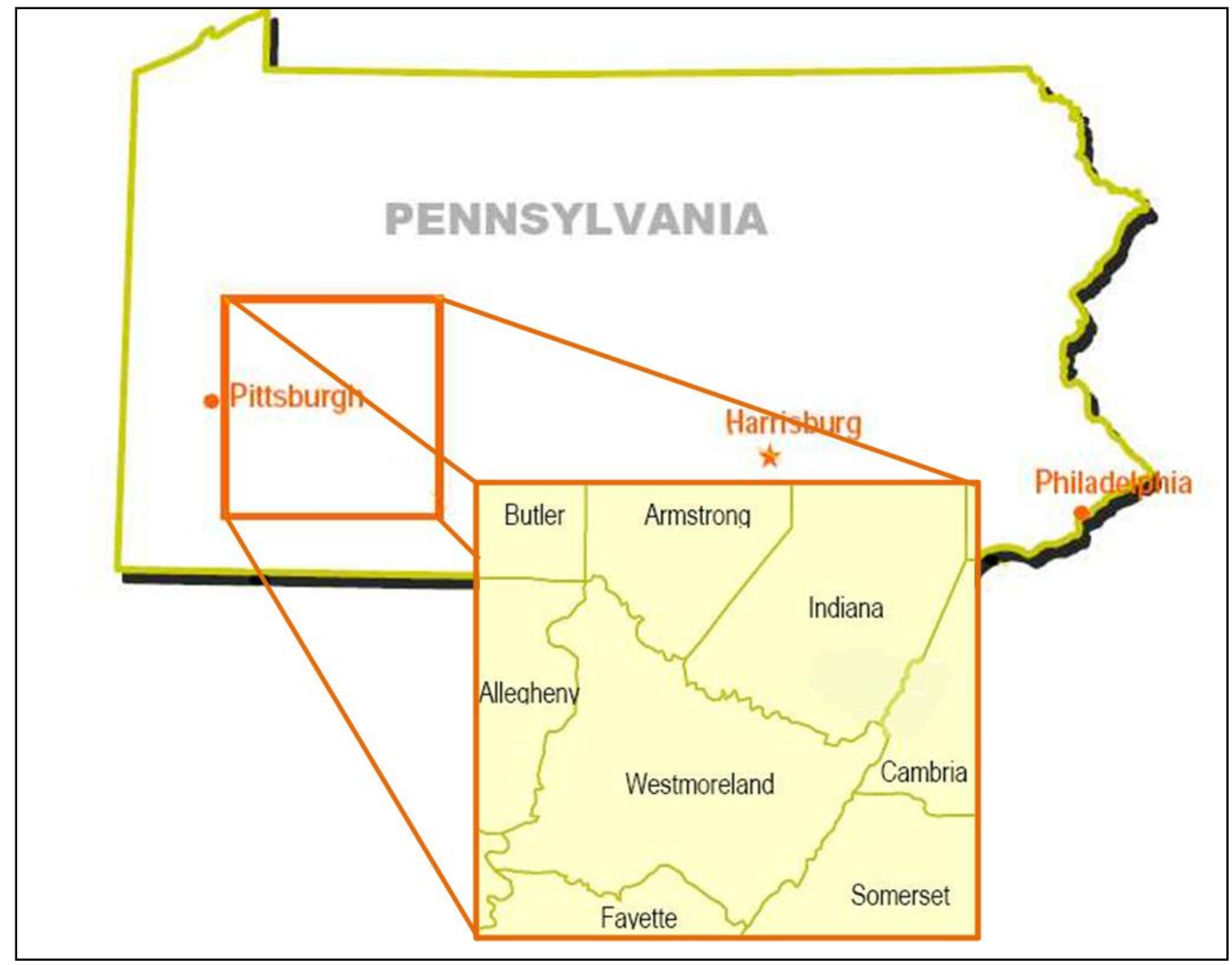

Figure 1. Study area, Westmoreland County, Pennsylvania (modified from McDaniel, 2006). 


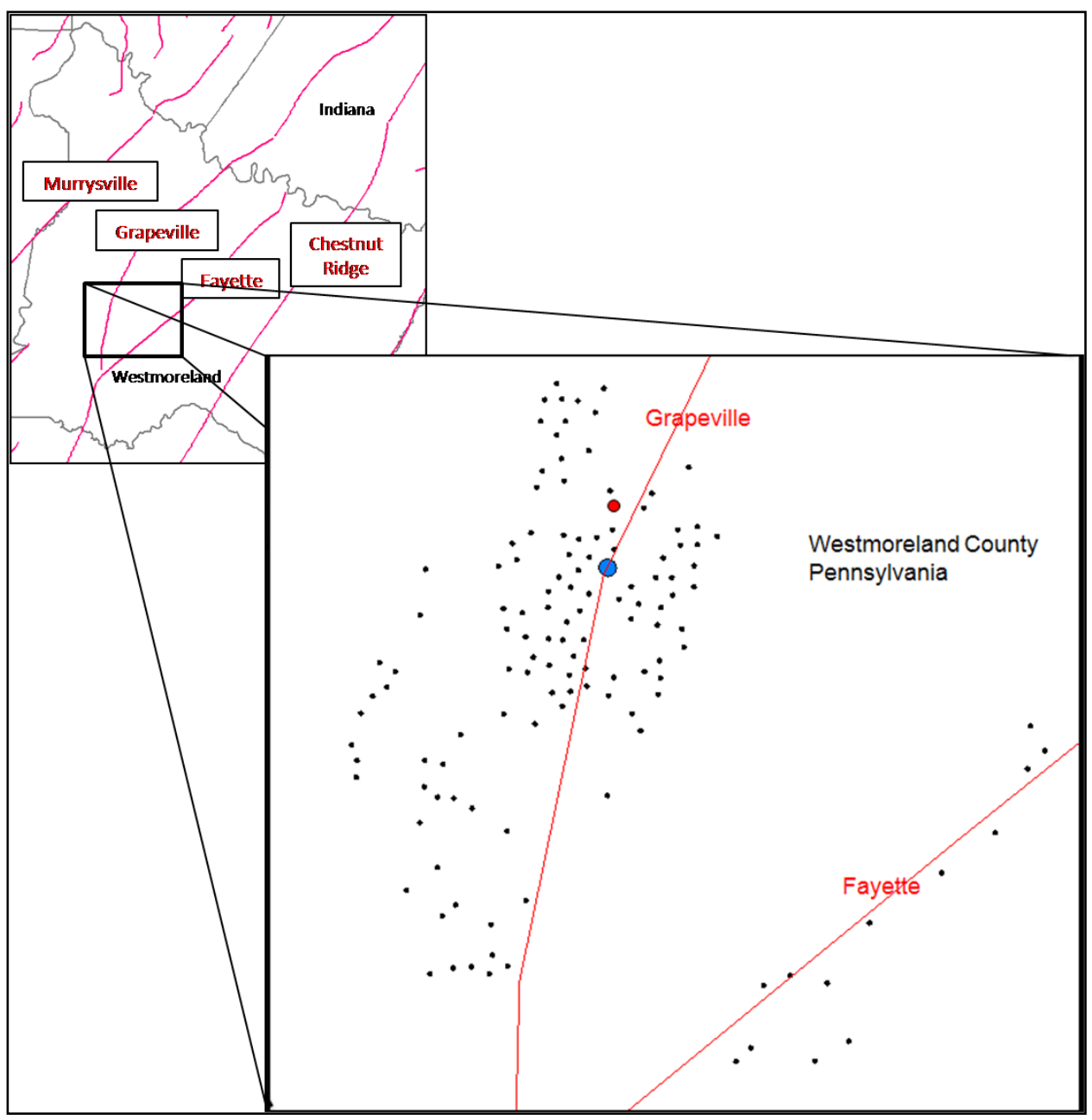

\section{Map Key}

- Well
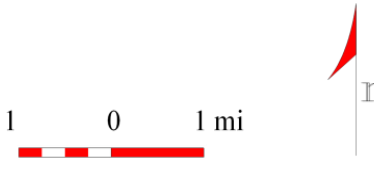

Type Log Well

Sidewall Core

- Anticline Axis

Figure 2. Westmoreland County, Pennsylvania base map. The red lines trending northeast-southwest indicate anticlinal hinge traces (modified from McDaniel, 2006). 

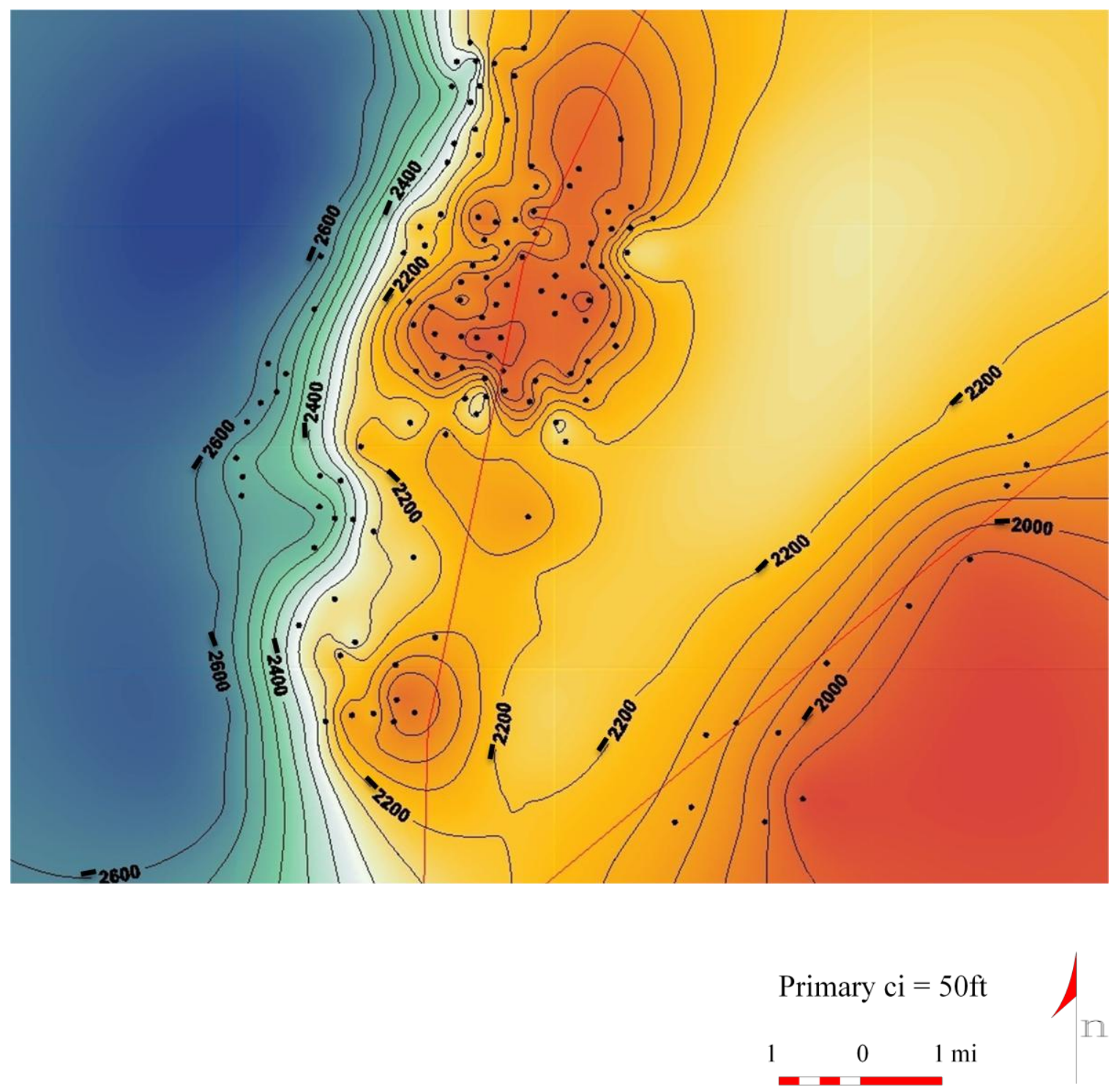

Figure 3. Study area subsurface (subsea) structure map for the top of the Fifth sandstone. Red indicates structural highs and blue indicates structural lows. Contour interval (ci) is 50 feet $(15 \mathrm{~m})$. 


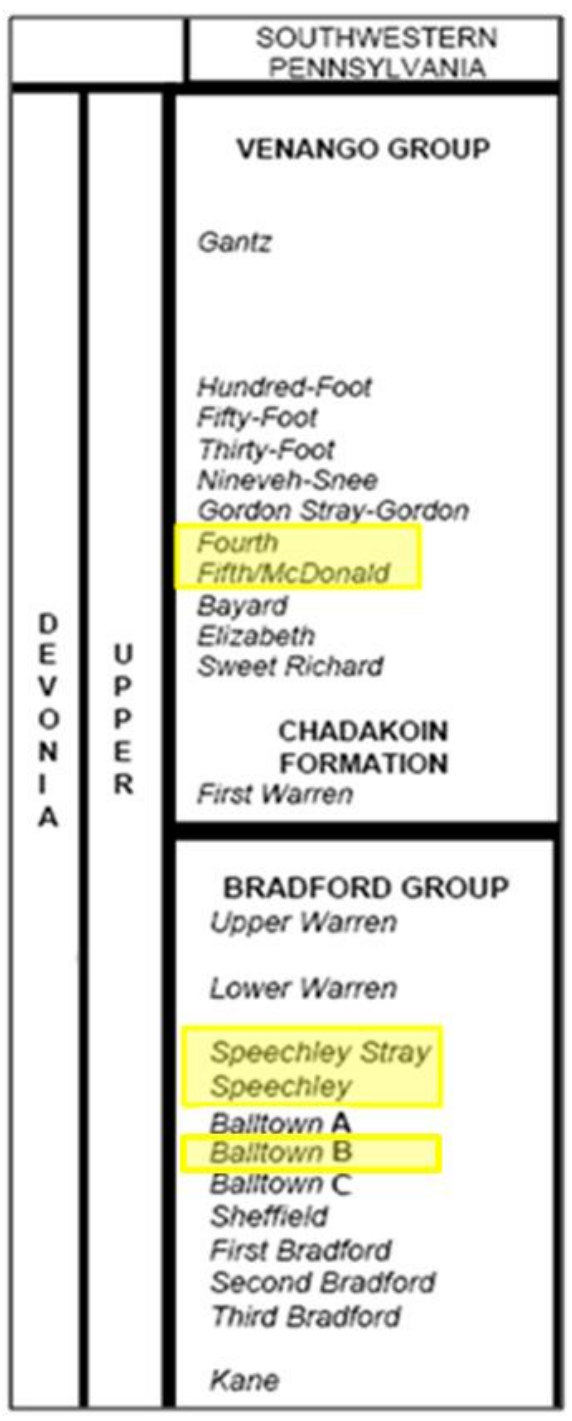

Figure 4. Stratigraphy of the Upper Devonian in study area. Formal lithostratigraphic terminology shown in bold. Commonly used drillers' terminology shown in italics. Studied units are highlighted (modified from Patchen et al., 1997). 


\section{GEOLOGIC BACKGROUND}

In the Late Devonian (385-360 ma), North America was located approximately at zero to thirty degrees south latitude (Figure 5), and had a warm climate that ranged from dry-subhumid to moist-subhumid to humid (Cecil et al., 2004). During this period, plate interactions between North America and the Avalonian terrain produced an elongate thrust-fold mountain belt that spanned from Canada to Alabama (Williams and Hatcher, 1982). This event, known as the Acadian orogeny, also increased subsidence rates within the adjacent craton, generating a peripheral foreland basin (Allen and Allen, 2005). In response to the tectonic uplift, large volumes of sediment were shed from the Acadian highlands and transported west across a sloping coastal plain and into the newly rejuvenated Appalachian basin (Sevon, 1985). This body of sediment (the Catskill delta complex) was deposited throughout the late Devonian and supplied the entire Appalachian basin (Figure 6). The Catskill delta complex continued to prograde westward as fluvial systems deposited numerous deltas along the foreland ramp. During the late Devonian, there were five major delta systems that prograded westward and dominated the foreland ramp (Figure 7). Two of these delta systems deposited the Bradford and Venango groups (Boswell and Donaldson, 1988). Deltas were elongate, discontinuous, and separated by interdeltaic shales (Dennsion, 1985). 


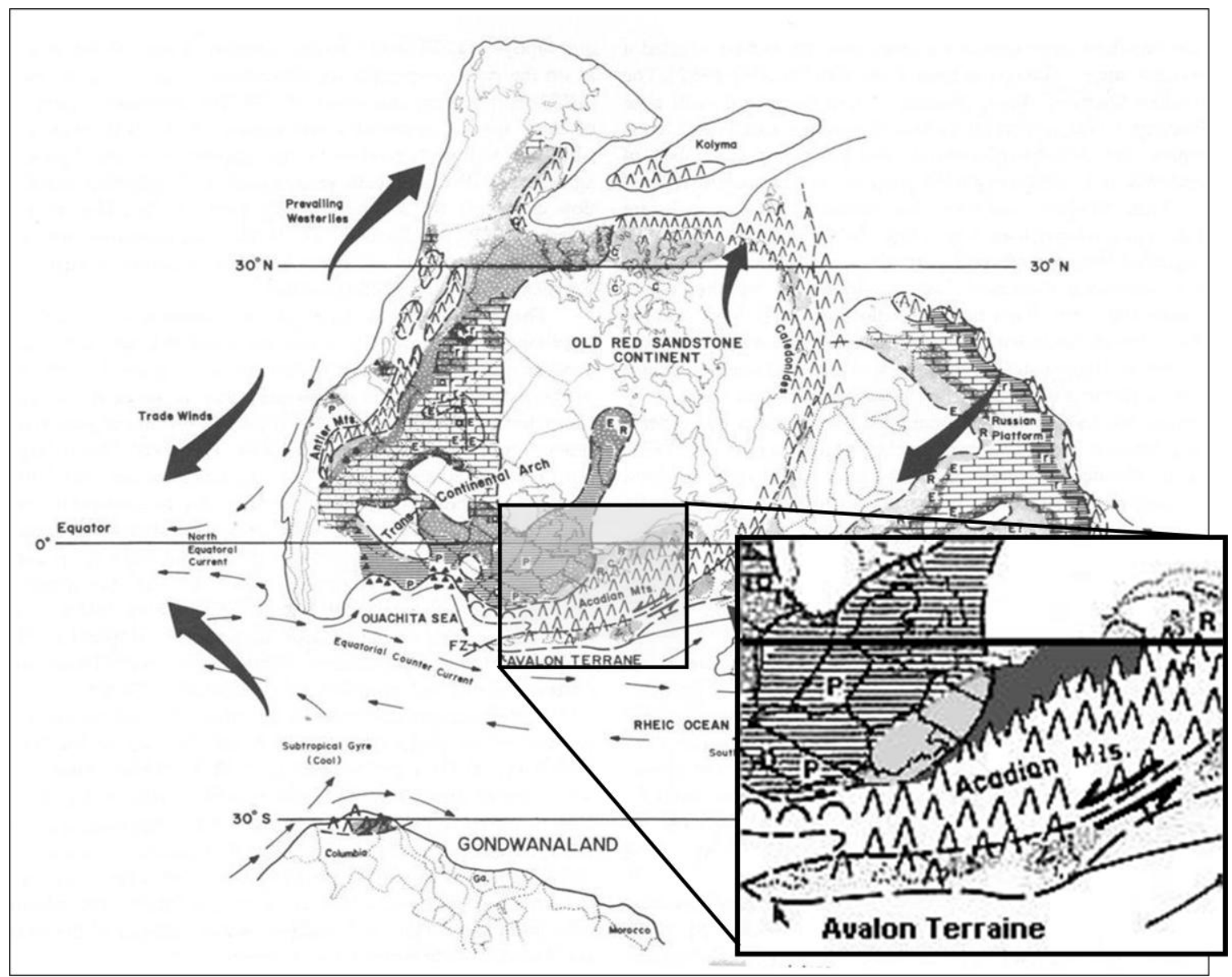

Figure 5. Late Devonian paleogeography during the Acadian orogeny (modified from Ettensohn, 1985). 


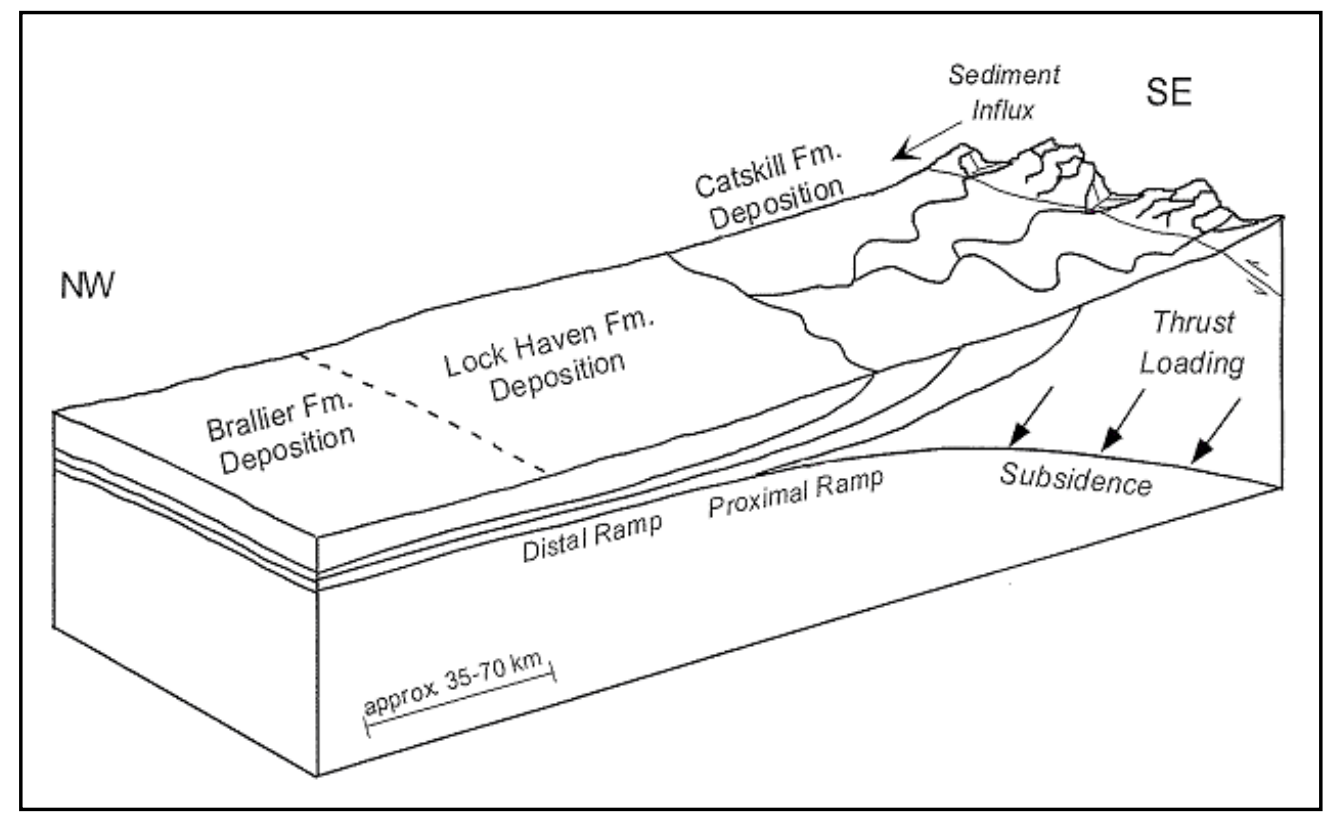

Figure 6. Upper Devonian foreland ramp depositional model ( from Castle, 2000). 


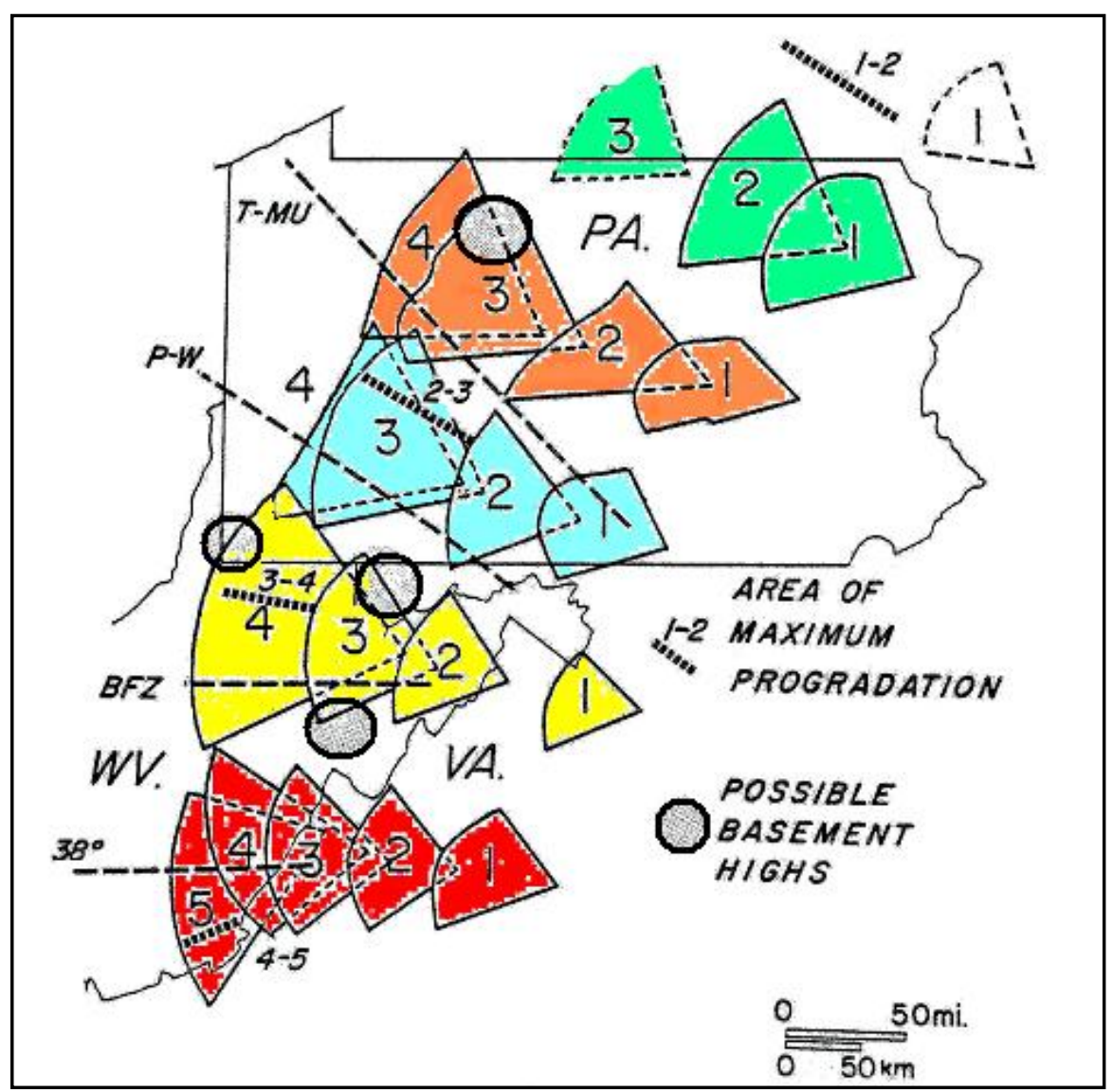

Figure 7. Upper Devonian Catskill complex delta systems prograding westward (from Boswell and Jewell, 1988). 
In the latest Devonian, maximum progradation of the Catskill delta complex was achieved west of the Acadian highlands followed by two separate transgressions that forced the shoreline back to the east (Boswell et al., 1988). This complex depositional history produced the various marine, non-marine, and transitional marine facies that comprise the delta complex. In west-central Pennsylvania, Upper Devonian rocks of the Catskill delta complex can be split into five magnafacies according to Harper and Laughrey (1987); these include deep-basin black shale, turbidite or slope sediments, fine-grained shelf sediments, coarse-grained deltaic sediments, and terrestrial red beds.

The Bradford and Venango reservoirs of the Catskill delta complex were deposited during the Famennian. During this period, Acadian tectonism ceased, and relative sea-level changes within the basin were controlled primarily by eustatic sea-level fluctuations and variations in sedimentation (Hopkins, 1988). The Bradford and Venango reservoirs were deposited in a variety of paleoenvironments along the eastern margin of the foreland basin. Hopkins (1988) interpreted paleoenvironments of the Bradford and Venango as shore-tied shoal, ebb tidal delta, inlet fill, interdeltaic barrier, delta rim barrier, distributary bar, tidal channel, estuary channel, and river channel. 


\section{RESERVOIR GEOLOGY}

In general, the Upper Devonian hydrocarbon trapping mechanisms are stratigraphic and result from vertical and horizontal facies changes, producing highly discontinuous sandstone reservoirs. However, for some reservoirs structural position has significantly affected production (Harper and Laughrey, 1987). Porosity in the Upper Devonian sandstone reservoirs is largely secondary porosity generated by dissolution of metamorphic and sedimentary rock fragments (Smosna and Bruner, 1997). Smosna and Bruner (1997) found that in the Upper Devonian sandstone reservoirs, mechanical compaction can eliminate primary porosity, while later dissolution can generate as much as five percent secondary porosity. Reported average porosity and permeability in these reservoirs are 8.5 percent and 0.003 md (millidarcy) (Harper and Laughrey, 1987).

Likely source rocks for the Upper Devonian reservoirs are the Devonian Burket and Marcellus black shale units (Laughrey et al., 2004). These black shale units are interpreted to have formed in anaerobic conditions in relatively shallow seas. Petrographic analyses determined that total organic carbon (TOC) is fifteen to twenty percent (Ettensohn, 1985). Laughrey and others (2004) have found these black shale units to be post-mature (vitrinite reflectance of 2.81 to 3.0 ), and contain type II kerogen. 
Fifth and Bayard Sandstone Reservoirs

Boswell and Donaldson (1988) determined that in southwest Pennsylvania the Fifth and Bayard sandstone reservoirs are typically elongate in a northeast to southwest strike direction that can be correlated over long distances. Reported maximum thickness of each individual sandstone reservoir is 25 feet $(7.6 \mathrm{~m})$ (Boswell and Donaldson, 1988). The individual sandstone reservoirs were interpreted as deposited as near-shore wavedominated deltas during tectonic quiescence (Boswell and Donaldson, 1988). In West Virginia, Jewell (1988) identified strike trends and log signatures that are consistent with the interpretation made by Boswell and Donaldson (1988); however, the author noted a secondary occurrence of dip-trending deposits.

Harper and Laughrey $(1987 ; 1989)$ characterized the petrography of the Venango sandstone reservoirs at a regional scale. Harper and Laughrey (1989) correlated the Fifth and Bayard sandstone reservoirs to facies equivalents in outcrops nearby. They determined that these sandstone reservoirs range from coarse grained to conglomeratic and poorly to well sorted (Harper and Laughrey, 1989). The composition of the sandstone reservoirs includes feldspathic and lithic greywacke, sublitharenite, and quartz arenite. Quartz comprises 65 to ninety percent of the sandstone reservoirs, feldspar comprises up to ten percent, and lithics range from one to fifteen percent. Lithic grains are composed of shale, carbonate, and metamorphic rock fragments. Porosities in the sandstone reservoirs range from eight to fifteen percent with a permeability range of 0.1 to $2.9 \mathrm{md}$ (Harper and Laughrey, 1989). However, in my study area LaSota (1988) reported that porosities in the Fifth and Bayard sandstone reservoirs range from three to six percent. 
Speechley Stray, Speechley, and Balltown B Sandstone Reservoirs

The Speechley through Balltown B sandstone reservoirs commonly exhibit diporiented trends that were interpreted as marine shelf and turbidite deposits (Horsey, 1978). Boswell (1988) also interpreted these trends as turbidites, and concluded that these sandstone reservoirs were deposited thirty to fifty miles west of the paleoshoreline (Figure 8). Murin and Donahue (1984) determined that thicknesses rarely exceed 33 feet (ten $\mathrm{m}$ ) and also postulated that the sediments accumulated as a result of current reworking and deposition was controlled by shelf topography.

Laughrey and others (2004) characterized the petrography of the Speechley through Balltown B sandstone reservoirs at well locations to the northeast of my study area. The authors determined that these sandstone reservoirs range from very fine grained to fine grained and moderately to well sorted. The sandstone reservoirs were primarily composed of sublitharenite with the remainder being arkosic arenite, subarkoses and lithic arenite (Laughrey et al., 2004). Detrital grains comprise 71 percent of the bulk mineral composition, approximately fifty percent of that being various forms of quartz (Laughrey et al., 2004). Lithic grains averaged nine percent and included large amounts of metamorphic rock fragments, and smaller amounts of sedimentary and igneous rock fragments. Laughrey and others (2004) found that the average feldspar content was ten percent, while clay content averaged 8.5 percent with chlorite being the most abundant clay followed by kaolinite and minor amounts of illite. Reported porosity in the Speechley through Balltown B averages 6.7 percent, and permeability averages 0.04 md (Murin and Donahue, 1984). 


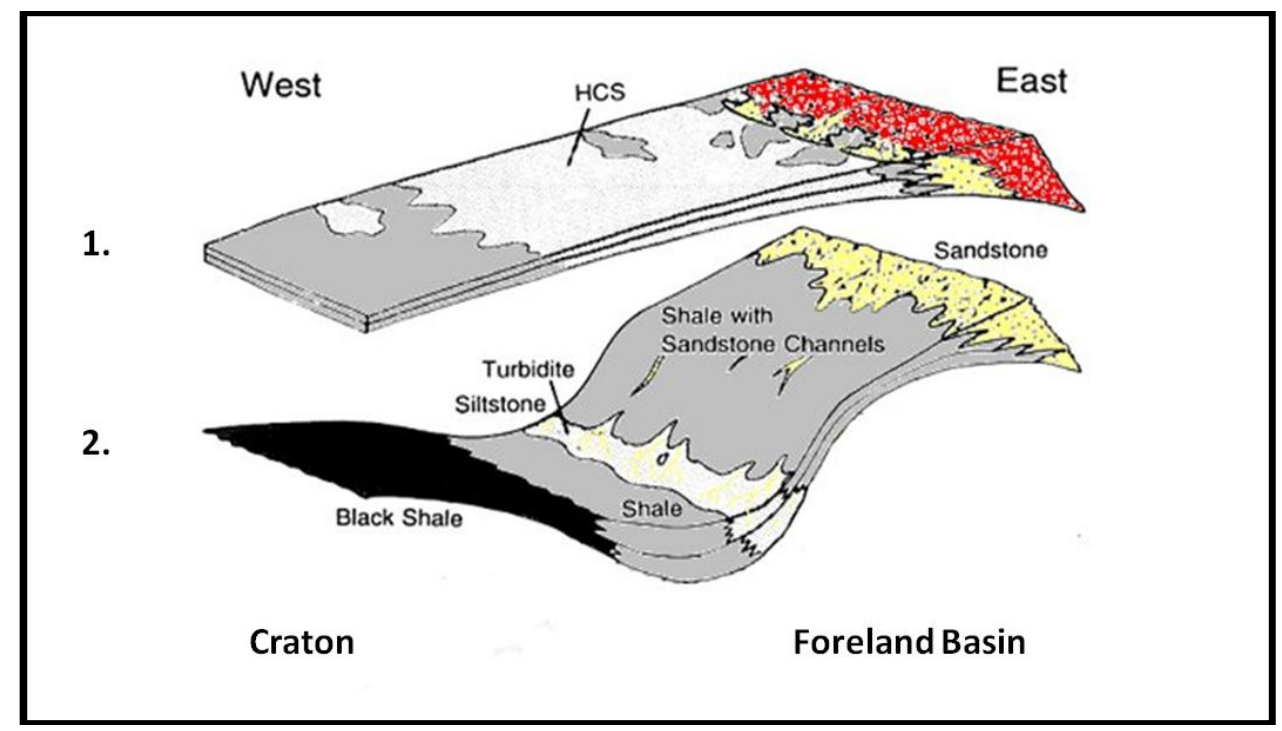

Figure 8. Image 1 shows shallow-sloped basin during deposition of the Venango Group. Image 2 shows steeper-sloped basin during Bradford Group deposition (modified from Boswell and Donaldson, 1988). 


\section{METHODOLOGY}

A total of 135 geophysical logs provided by Dominion Exploration and Production Inc. in Westmorland County, Pennsylvania constitute the data set for this study. The logs are displayed as either digital log ascii standard (LAS) files or raster images. Where well control was sparse, the Pennsylvania's IRIS website was used to provide additional control of stratigraphic horizons. Typically the logs are an open-hole suite consisting of gamma ray, neutron porosity, compensated density, density caliper, medium induction, deep induction, audio, and temperature curves. Because the study area is limited by one set of sidewall cores, log curves were relied on for subsurface facies analysis. In order to broaden the digital data base, many of the raster images were digitized.

To begin identifying and correlating the Bradford and Venango sandstone units, a type log was established in the center of the study area (Figure 9). Digital data for each well log were entered into subsurface modeling software (Geographix ${ }^{\mathrm{tm}}$ ), where they could be viewed in different internal applications. Correlations were made in Geographix $\mathrm{X}$-Section ${ }^{\mathrm{tm}}$ by radiating out from the established type log and tying back to make numerous loops. This procedure was repeated in order to consistently identify and correlate individual sandstone units. Gamma-ray cutoffs were used to identify and correlate sandstone units and significant marker beds such as flooding surfaces (Figure 9). Based on past experience in the Appalachian basin, a gamma ray of eighty API or less is considered to be clean sandstone (Figure 10). Higher API values indicate radioactivity within a rock, commonly associated with clay or organic rich rocks such as shale (VanWagoner et al., 1990). Bulk density cutoffs were used to identify and correlate sandstone reservoirs. A bulk density of $2.55 \mathrm{~g} / \mathrm{cm}^{3}$ or less (eight percent porosity or greater) is considered to indicate a reservoir with potential hydrocarbons (Figure 10). 


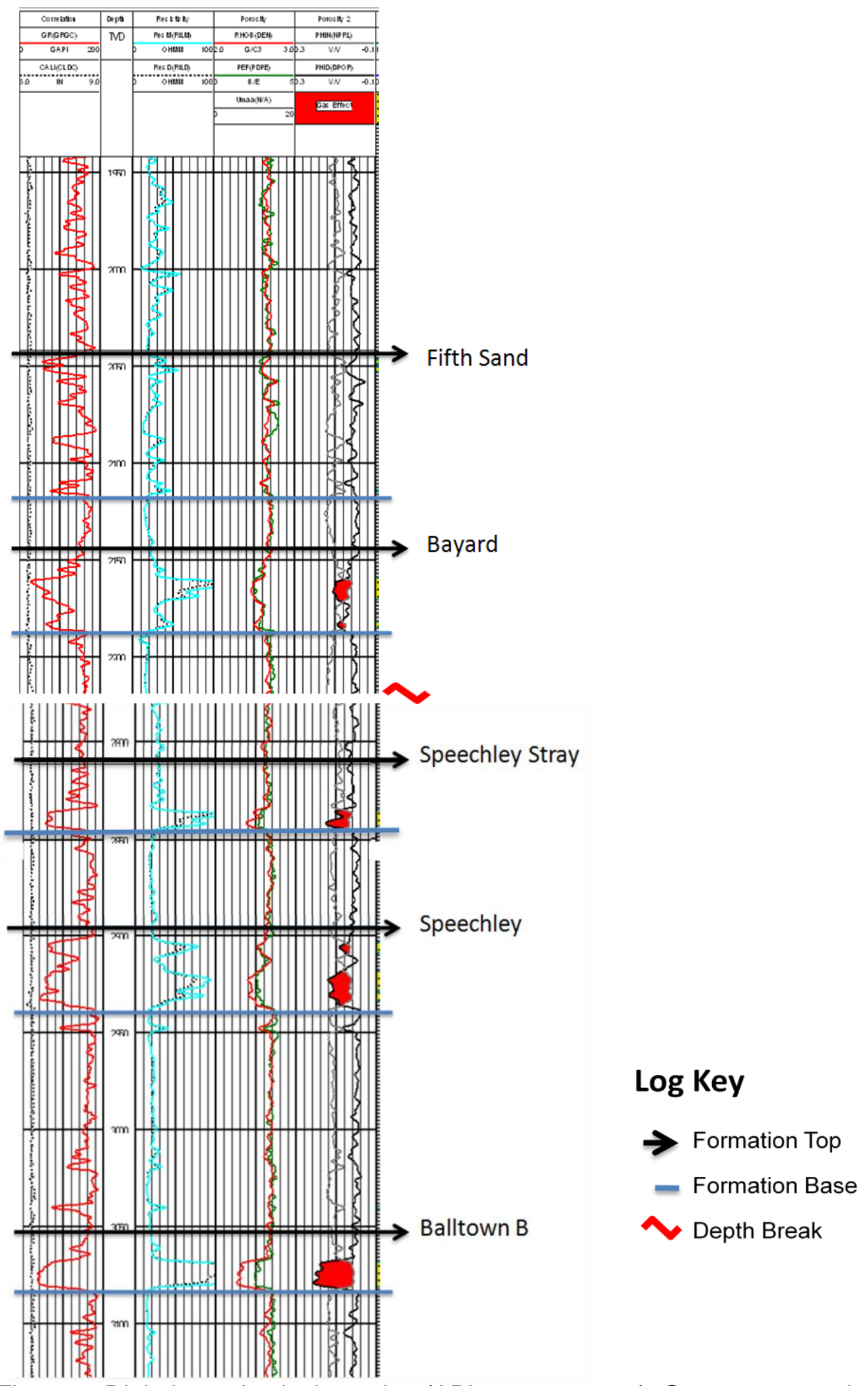

Figure 9. Digital geophysical type log (API \#3712925989). Gamma ray, resistivity, photo electric, density and porosity curves are located in tracks one, two, three and four respectively. Crossover of the density and neutron porosity logs is highlighted in red and indicates gas-rich intervals. Location of type log well is shown in Figure 2. 


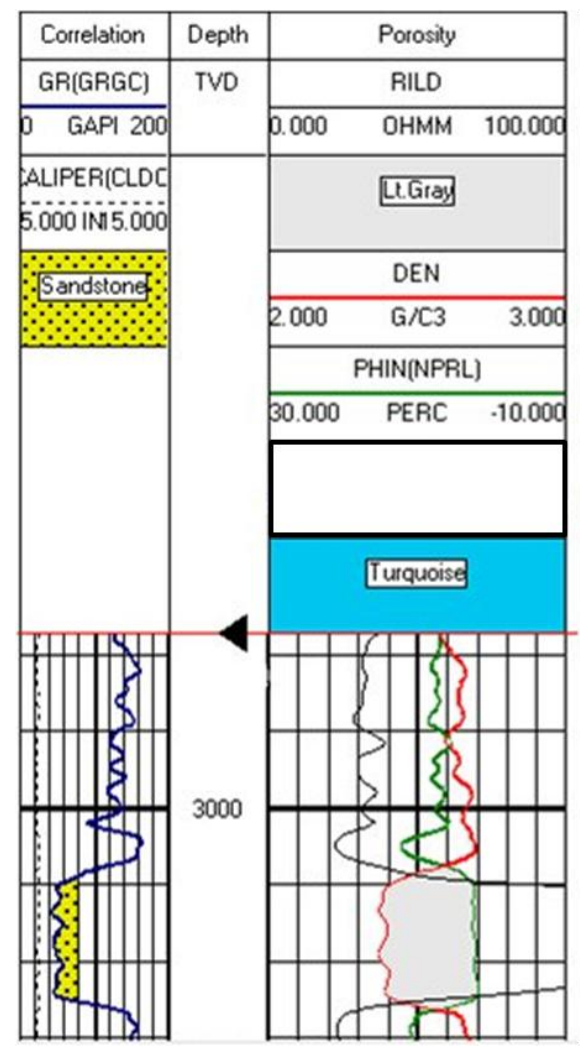

Figure 10. Digital geophysical log (LAS). Gamma ray curve shown in track 1 (blue). Clean sandstone less than the eighty API cutoff shown in yellow. Bulk density curve shown in red with the pay cutoff $\left(<2.55 \mathrm{~g} / \mathrm{cm}^{3}\right)$ shown in grey. Deep induction curve shown in black. 
Once the top and base of individual sandstone units were picked and recorded, a grid of strike and dip cross sections were constructed across the study area (Figure 11). A total of thirteen strike and dip primary cross sections were made. Each cross section was used to identify the geometry of the sandstone units as well as its vertical distribution and stacking pattern.

For this study, various maps were generated using the Zone Manager ${ }^{\text {tm }}$ application within Geographix ${ }^{\mathrm{tm}}$. Maps including water saturation, degree of crossover, structure, and net sandstone were constructed in order to characterize individual sandstone units. Maps were constructed by highlighting zones of interest, and saving attributes of interest to a zone (attributes such as the sum of sandstone reservoir thickness is a common attribute to link to a zone). Once data were stored, they were converted into map layers. Map building parameters were set between 250 to 500 feet (75 to $150 \mathrm{~m}$ ) for grid spacing, and 2500 to 5000 feet (750 to $1500 \mathrm{~m}$ ) for data radius of influence. A minimum curvature algorithm was used to grid the data. These gridding parameters were selected in order to honor the data points and to have adequate resolution while displaying detailed trends.

PRIZIM ${ }^{\mathrm{tm}}$, an application in Geographix ${ }^{\mathrm{tm}}$, was crucial for the study. This application was employed to analyze reservoir parameters through log analysis techniques. Provided a standard geophysical log suite, PRIZIM ${ }^{\mathrm{tm}}$ allows one to write equations and run calculations in order to determine reservoir characteristics. Important variables such as water saturation $\left(S_{w}\right)$, degree of gas crossover effect, and mineral content (RHOmaa-Umaa) within reservoirs were measured across the study area. 


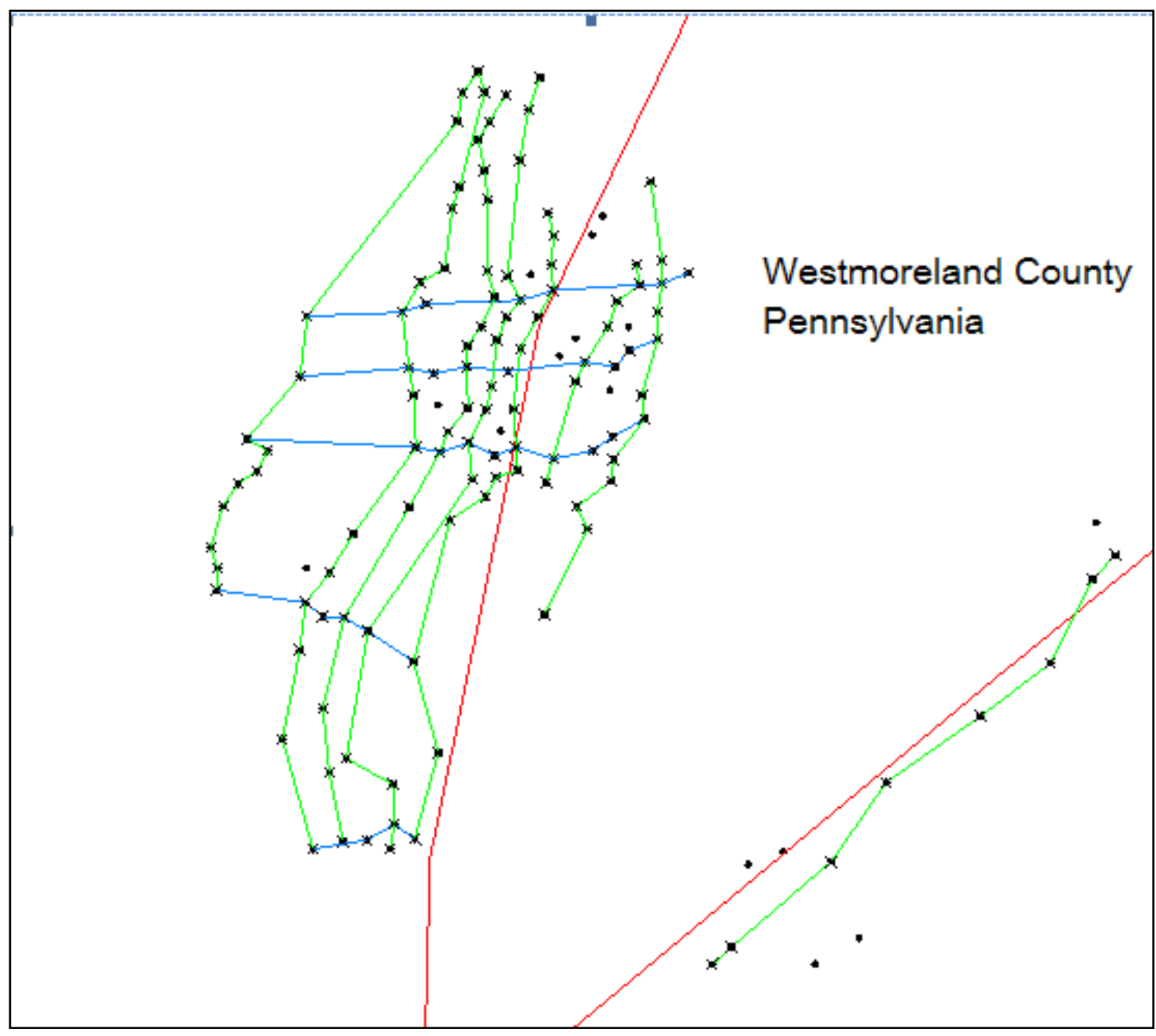

\section{Map Key}

- Well

- Strike Cross Sections

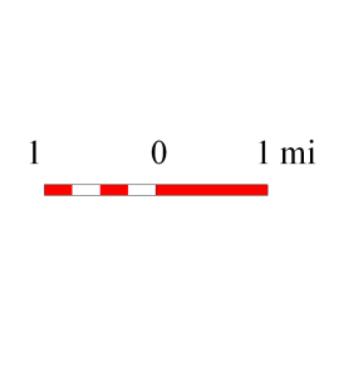

- Dip Cross Sections

- Anticline Axis

Figure 11. Base map showing location of cross section grid. See figure 2 for location of base map. 
The Archie equation (Figure 12) was used to calculate water saturation by relating resistivity to fluid types and porosity (Asquith and Krygowski, 2004). By using the Archie equation, water saturation values within individual reservoirs could be analyzed and mapped. Although water saturation is not of primary interest, it can be very useful since zones with low water saturation have higher hydrocarbon saturation. The typical standard for the Appalachian basin is to target zones with fifty percent or greater hydrocarbon saturation.

\footnotetext{
Archie Equation

$S_{w}=\left[\left(a / F^{m}\right)^{*}\left(R_{w} / R_{t}\right)\right]^{(1 / n)}$

$S_{\mathrm{w}}=$ water saturation

$\mathrm{F}=$ porosity

$\mathrm{R}_{\mathrm{w}}=$ formation water resistivity

$\mathrm{R}_{\mathrm{t}}=$ observed (true) resistivity

$a=$ tortuosity factor ( 0.81 for consolidated sandstone)

$\mathrm{m}=$ cementation factor ( 2.0 for consolidated sandstone)

$\mathrm{n}=$ saturation exponent (generally 2 )
}

Figure 12. Archie Equation for determining water saturation from porosity and resistivity (modified from Asquith and Krygowski, 2004). 
Porosity $(F)$ is obtained from well logging tools. Resistivity of water $\left(R_{w}\right)$ is the resistivity of formation water at formation depth and temperature (measured in the field). True resistivity $\left(R_{t}\right)$ is the resistivity of the undisturbed formation which is assumed to be the same as the value from the deep induction log. The cementation exponent $(\mathrm{m})$ and tortuosity factor (a) vary with grain size, grain size distribution, and the complexity of paths between pores (Asquith and Krygowski, 2004). The saturation exponent (n) varies between 1.8 and 2.5, however, it is typically assumed to be 2.0. Values of $(m),(n)$ and (a) are empirically derived and difficult to calculate, therefore constants have been determined based on different formation types.

To determine mineral compositions, RHOmaa-Umaa cross plots were used in conjunction with sidewall cores and published thin section analysis. Bulk density, neutron porosity, and photoelectric logs were utilized to generate RHOmaa (the apparent matrix density) and Umaa (the apparent matrix photoelectric coefficient). When RHOmaa and Umaa are plotted on a ternary diagram with mineral values for endpoints, the mineral composition of the reservoir can be estimated. Calcite, quartz and dolomite are the most common endpoints for sedimentary rocks, but any variety of three endpoints can be chosen. For this study feldspar, illite, chlorite, quartz, and calcite were used because they were the most abundant minerals observed in the sidewall cores when analyzed by Core Labs. The RHOmaa-Umaa approach is the most direct method of determining mineral composition. Other methods such as $\mathrm{M}-\mathrm{N}$ cross plots can be used to determine mineral composition; however, the method used in this study is considered a more powerful mineral discriminator because it suppresses porosity and the presence of fluids (Doveton, 1994). 
Sidewall cores were available from a single well (API \# 3712922727) in the study area (location shown in figure 2). Six sidewall cores were taken every five feet within the Speechley sandstone unit and analyzed by XRD in order to determine mineral composition. Since this well did not have a suite of logs including neutron porosity, density porosity, and photoelectric effect, RHOmaa - Umaa cross plots could not be created for this well. Instead, the nearest neighboring wells within 2000 feet $(600 \mathrm{~m})$ were employed for comparison. The top of the Speechley was correlated to four neighboring wells and plotted with the XRD data from the core (figure 13). Normalized XRD analysis indicated 51 percent quartz, six percent illite and 41 percent calcite. RHOmaa -Umaa mineral compositions in the nearby wells showed similar values.

Published petrologic results were also available from a full-bore corel (the Sportsman well) just two miles north of the study area. LaSota (1988) analyzed 14 thin sections of the Fifth sandstone unit in the Sportsman Well. The sandstone was split into three intervals. Since a geophysical log was not available for this well, the nearest northern wells in the study area were employed to compare the published results to the RHOmaa - Umaa derived mineral compositions. The basal Fifth sandstone was correlated to four wells and plotted with the author's results (figure 14). LaSota's (1988) results indicated ninety percent quartz, four percent chlorite and six percent feldspar. RHOmaa -Umaa derived mineral compositions showed nearly identical values.

After the RHOmaa - Umaa determined mineral compositions were validated by comparison with the sidewall core data, Umaa values were calculated from the log data and an average Umaa value over each zone was computed. This average Umaa value was gridded to generate Umaa maps. Since Umaa is the product of the photoelectric effect (PE) log and bulk density log, Umaa maps were very useful in determining the 
change in matrix across the study area. For example, quartz has a PE value of 1.81 and a bulk density value of 2.64. The product of these two values is 4.78 . Thus, Umaa maps with values around five indicate quartz-rich rocks. Umaa values around seven are clayrich rocks, and Umaa values around thirteen are calcite-rich rocks. It was assumed that variations in quartz, clay, and calcite are linked to depositional environment and could be used to identify depositional facies.

Degree of crossover between neutron porosity and density porosity was also calculated with Prizim ${ }^{\mathrm{tm}}$ and mapped via Zone Manager ${ }^{\mathrm{tm}}$. By taking the maximum difference between these two curves, gas saturation can be quantified across the study area. This approach was taken instead of the traditional summed net pay because it is independent of sandstone thickness. Removing thickness as a variable allows other geologic parameters to be measured against gas saturation and reservoir quality. 


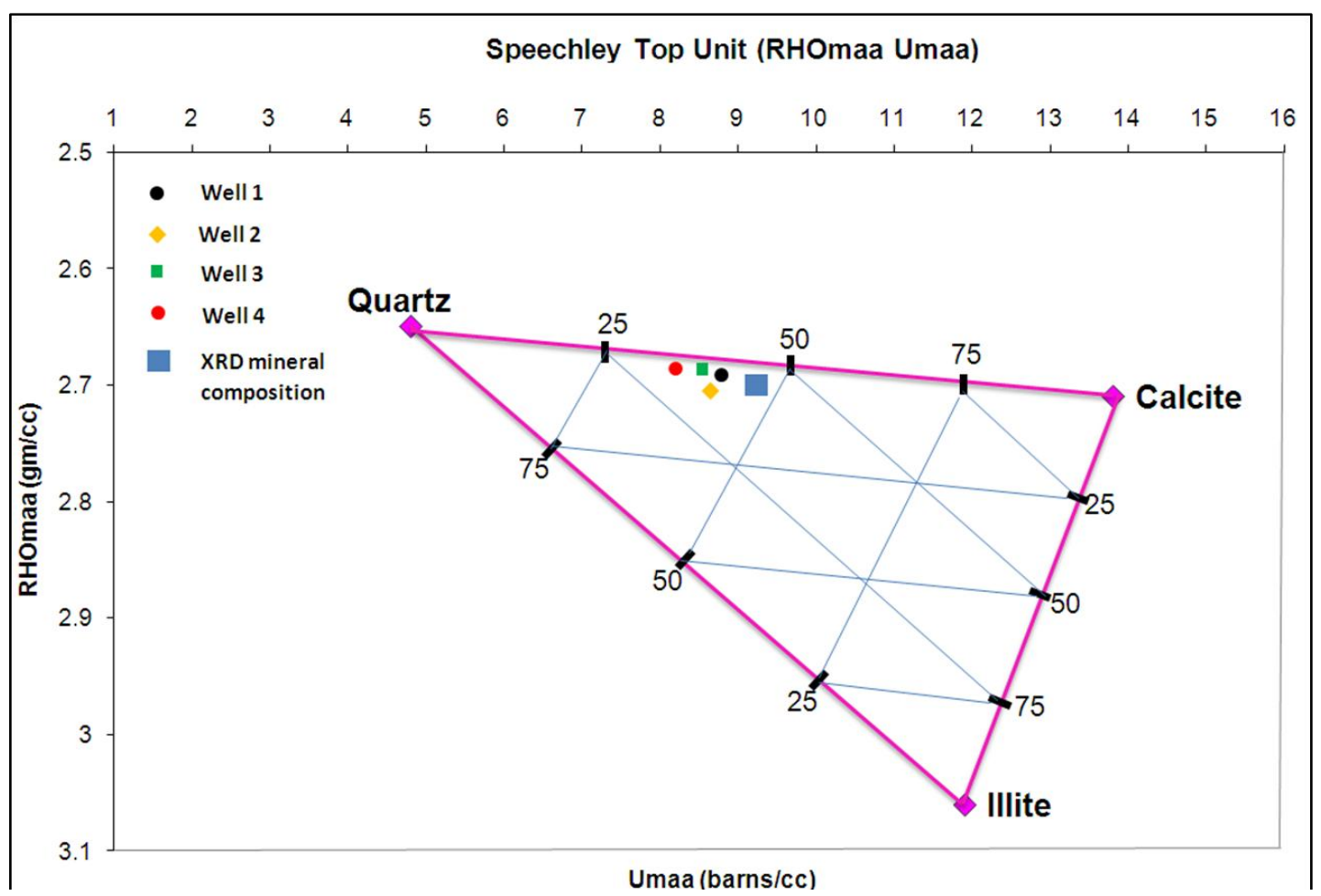

Figure 13. RHOmaa-Umaa derived compositions plotted with mineralogy derived from XRD analysis of a sidewall at the top of the Speechley sandstone unit (subsea depth of 2935 to -2945 feet). RHOmaa-Umaa determined mineralogy compares favorably with the mineralogy determined by XRD analysis. 


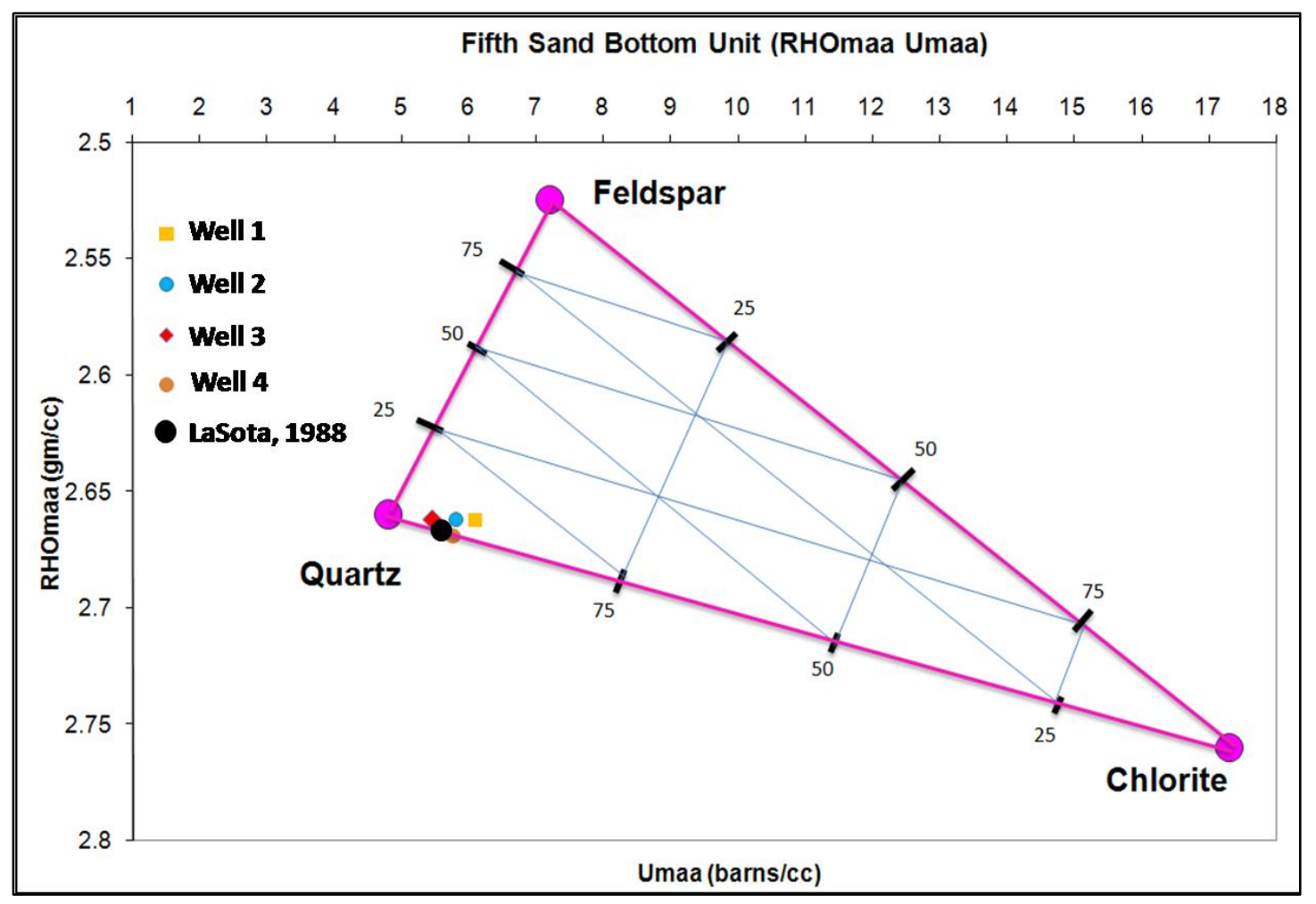

Figure 14. RHOmaa-Umaa derived mineralogical compositions for four nearby wells plotted with core mineralogical compositions derived from thin section analysis (LaSota, 1988 ) in the Sportsman core for the basal Fifth sandstone unit (subsea depth of -2120 to -2125 feet). 


\title{
DESCRIPTION AND INTERPRETATION OF THE BRADFORD GROUP SANDSTONE UNITS
}

\author{
Balltown B Sandstone Unit Description
}

The Balltown B sandstone unit for this study is defined as the interval from the bottom of the Balltown A unit to the top of Balltown $\mathrm{C}$ unit. Both units have distinctive shale breaks. In the study area, the sub-sea depth of the Balltown B unit ranges from 3000 to 3600 feet (900 to $1200 \mathrm{~m}$ ). In the south of the study area, this unit is insignificant and has a serrated log signature appearance indicating numerous shale partings. In the north of the study area, the log signature of the Balltown B unit shows a massive sandstone with a bell or blocky log signature (Figure 15). The sandstone is usually bound by a sharp basal contact with a fining upward sequence. The fining upward sequence indicates low shale content at the base with shale content increasing towards the top of the unit. This log response is commonly associated with tidal point bars, channel fills, or fluvial sandstone units (Wilson and Nanz, 1959).

The net sandstone map of the Balltown B unit shows a distinct lobe of sand with a channel-like morphology in the northern part of the study area (Figure 16). This sandstone unit has limited areal extent and trends in an east-west or dip direction that

cuts across the Grapeville anticline. The Balltown B unit has an average thickness of 7.8 feet $(2.4 \mathrm{~m})$ and a maximum thickness of 22 feet $(6.7 \mathrm{~m})$. In cross section, the lenticular nature of the Balltown B unit can also be seen as it thins rapidly to the north and south (Figure 17). In the cross section the thickest interval of the Balltown B unit appears to be associated with erosional down cutting and underlying bed are truncated. 
The Umaa map of the Balltown B shows that the lowest Umaa values coincide with the thickest section of the Balltown B. These Umaa values increase rapidly towards the edges of the sandstone thick. The low Umaa values of approximately five indicate very high quartz content in the middle of the thickest Balltown B with little or no calcite or clay material (Figure 18).

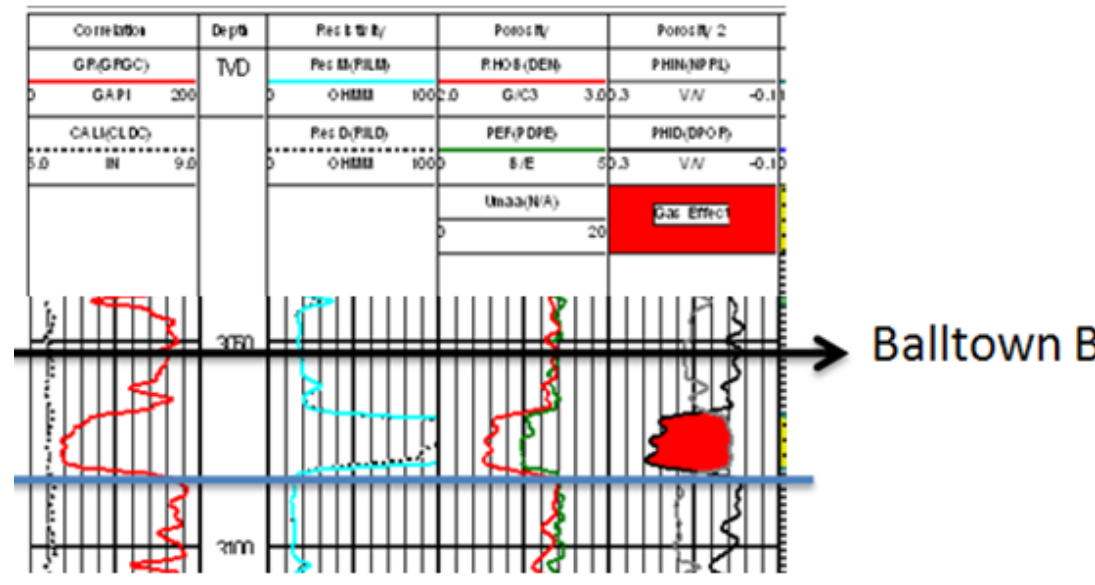

Log Key

$\rightarrow$ Formation Top

- Formation Base

Figure 15. Gamma ray log signature that characterizes the Balltown B sandstone unit. 


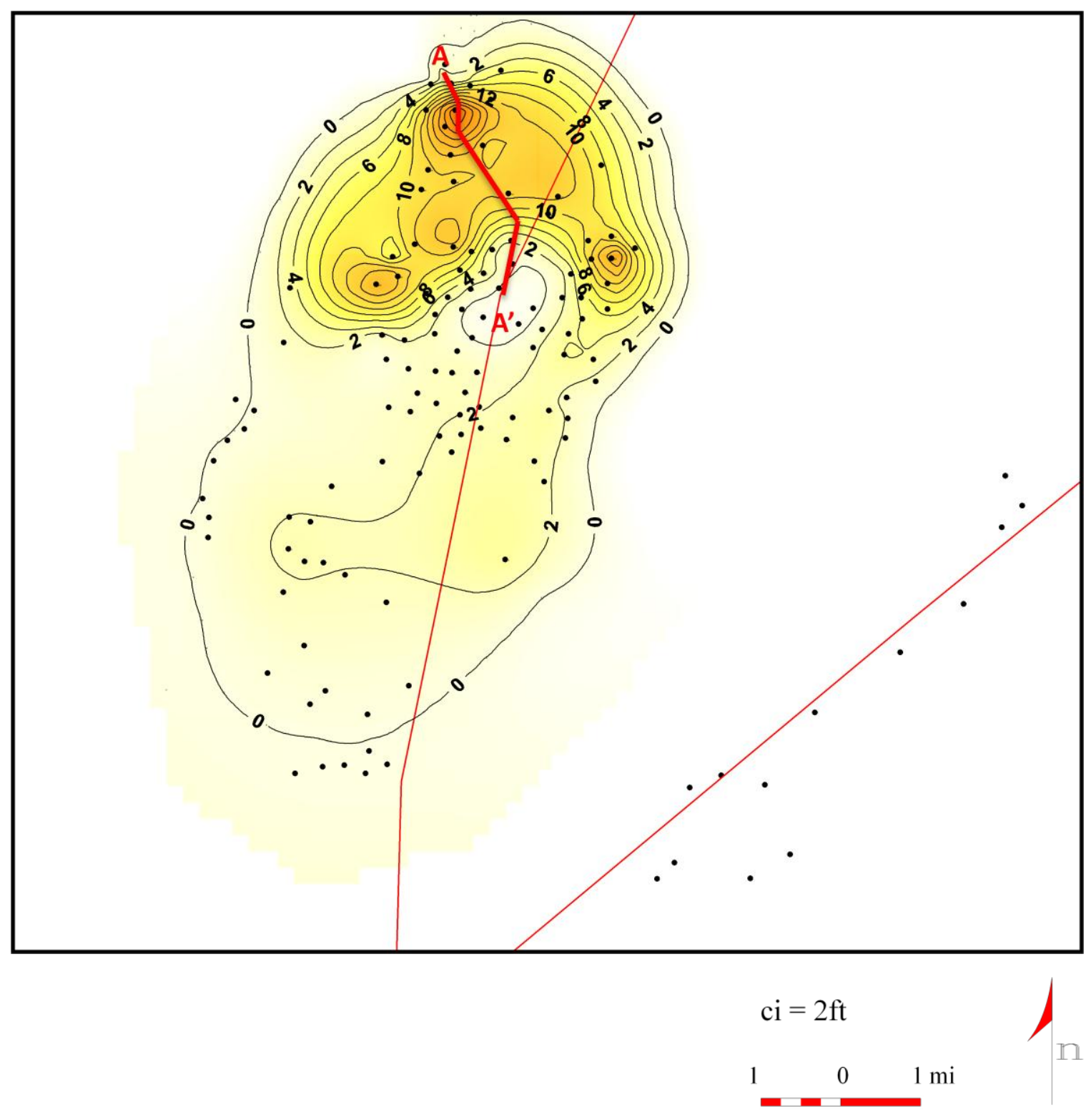

Figure 16. Balltown B net sandstone map. Orange area indicates thick sandstone sections decreasing to the white areas indicating thinner sandstone sections. Cross section A-A' shown in Figure 17. 


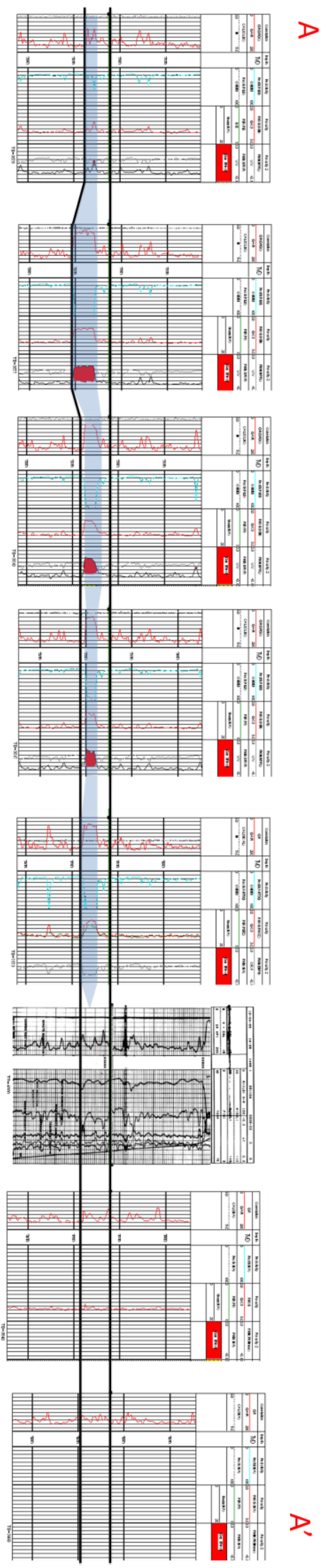

Figure 17. Stratigraphic cross section of the Balltown $B$ sandstone. The datum is the top of the Balltown B unit. Blue shading highlights where the API value is less than a hundred. The Balltown B sandstone unit thins to the north and south. 


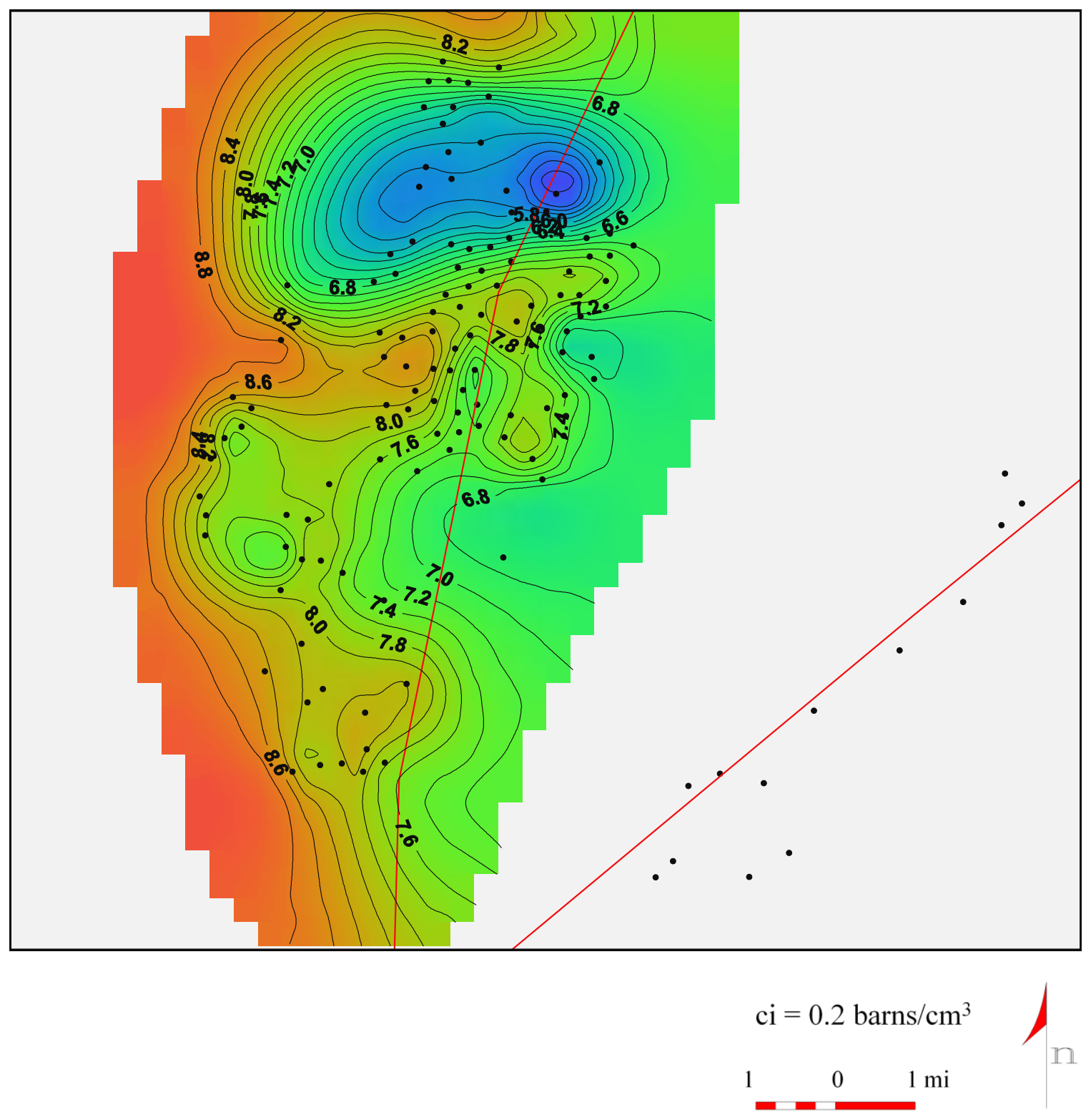

Figure 18. Balltown B sandstone Umaa map. Cool colors indicate low Umaa values suggesting quartz-rich rocks and warmer colors indicate higher Umaa values suggesting increased calcite or clay content. 


\section{Balltown B Sandstone Unit Interpretation}

This sandstone unit is interpreted as a fluvial deltaic channel deposit. This interpretation is supported by the following: 1) the net sand map shows limited areal extent, channel morphology and dip trend; 2) the logs and cross sections show a fining up sandstone unit with a sharp basal contact that is down cutting in cross-section; and 3) the Umaa map shows high quartz content in the area of thicker net sandstone indicating a higher energy environment that produced clean sediment. Cotter and Driese (1998) have identified a facies equivalent unit to the east (near the Appalachian structural front). They found the Balltown B unit was a cross laminated grey sandstone with grey fissile mudstone lenses. Depositional environment determined in outcrop was fluvial-deltaic or near-shore marine (Cotter and Driese, 1998). Approximately fifty miles (eighty $\mathrm{km}$ ) north of the study area, Anthony Johnson (2008) interpreted the sandstone unit as a channel deposit with similar east-west trends.

The Balltown B unit is interpreted as deposited within distributaries of a deltadominated coastal plain. The massive and blocky base of the Balltown B unit suggests deposition outpaced relative sea level within the study area. During this period, quartzrich terrigenous sediments prograded basinward across the shoreline. As sedimentation increased, more accommodation space was created as relative sea level dropped. Continued regression likely allowed for a further extension of the delta front and fluvial systems that supplied them. 


\section{Speechley Sandstone Unit Description}

For this study, the Speechley sandstone unit is defined as the interval from the bottom of the Speechley Stray unit to the top of Balltown A unit. Traditionally, the Speechley is identified and correlated as one sandstone unit, however, for this study the unit was further broken down into two sequences. Upper and lower sequences are separated by a distinct shale break. In the study area, the sub-sea depth of the Speechley unit ranges from 2900 to 3400 feet (880 to $1030 \mathrm{~m}$ ).

The lower Speechley sequence typically has a bell shaped log signature. The sandstone is bound by a sharp basal contact with a fining upward sequence (Figure 19). The fining upward sequence indicates a clean sandstone base that increases upwards in shale content. The net sandstone map of the lower Speechley shows an aerially extensive sandstone sequence which blankets the study area. This sandstone extends over the existing structure and has no obvious trends (Figure 20). The lower Speechley sequence has an average thickness of 16.5 feet (five $\mathrm{m}$ ) and a maximum thickness of 23 feet (seven $\mathrm{m}$ ). In cross section, the continuous nature of the lower Speechley sequence has a consistent signature from north to south (Figure 22). Down cutting at the base was also observed in cross section. The Umaa map of the lower Speechley sequence shows the lowest Umaa values coincide with the thickest section. The Umaa values remain low (between five and six) throughout the study area (Figure 23).

The upper Speechley sequence has varying log signatures including funnel, bell, blocky and serrated (Figure 19). The sandstone sequence is bound by a distinct shale break at the base. In map view, the upper Speechley sequence is aerially extensive, but has distinct lobes that are sporadically distributed. The upper Speechley sequence is thinner than the lower sequence with an average thickness of 8.5 feet $(2.6 \mathrm{~m})$ and a 
maximum thickness of approximately 23 feet (seven m) (Figure 21). The upper sequence blankets the entire area and the sandstone lobes have east-west trends. In cross section, the upper Speechley sequence can be identified consistently across the study area, however, the log signature changes (Figure 22). There is also evidence of reciprocal sedimentation in cross section and in map view. Thick sections of the lower Speechley sequence coincide with thin sections of the upper Speechley sequence and vice versa. The Umaa map indicates that higher Umaa values coincide with the thickest section of the upper Speechley sequence. This relationship is reversed from what was observed in the Balltown B unit and the lower Speechley sequence. Umaa values are also higher than what is observed previously (values range between six and nine), indicating higher calcite and clay contents (Figure 24).

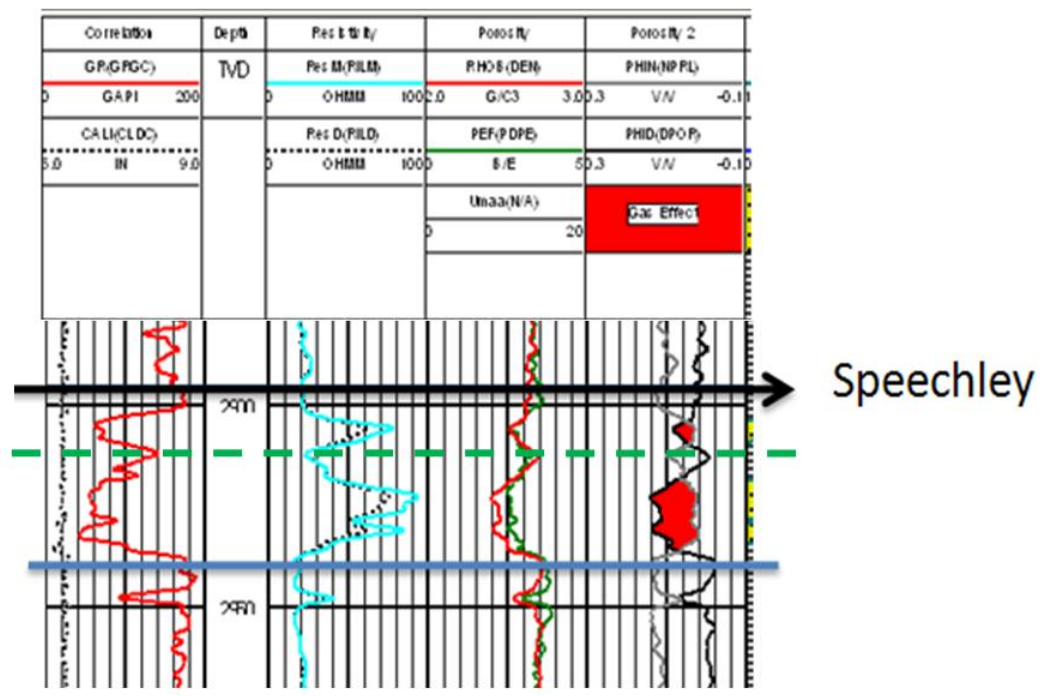

\section{Log Key}

$\rightarrow$ Formation Top

- Formation Base

- - Sequence Division

Figure 19. Gamma ray log signature that characterizes the Speechley sandstone unit. 


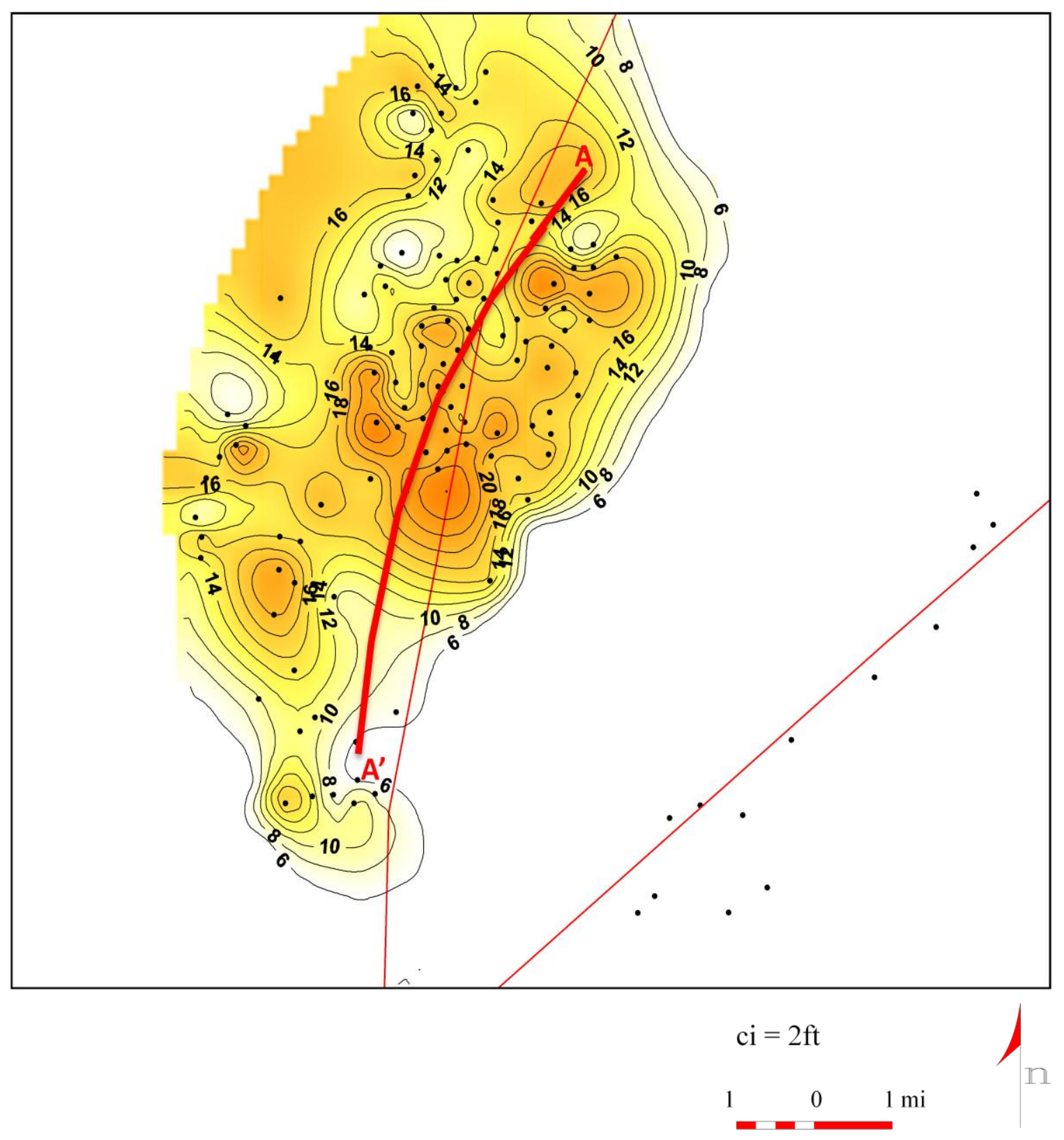

Figure 20. Net sandstone map of the lower Speechley sequence. Orange area indicates thick sandstone sections decreasing to the white areas indicating thinner sandstone sections. Cross section A-A' shown in Figure 22. 


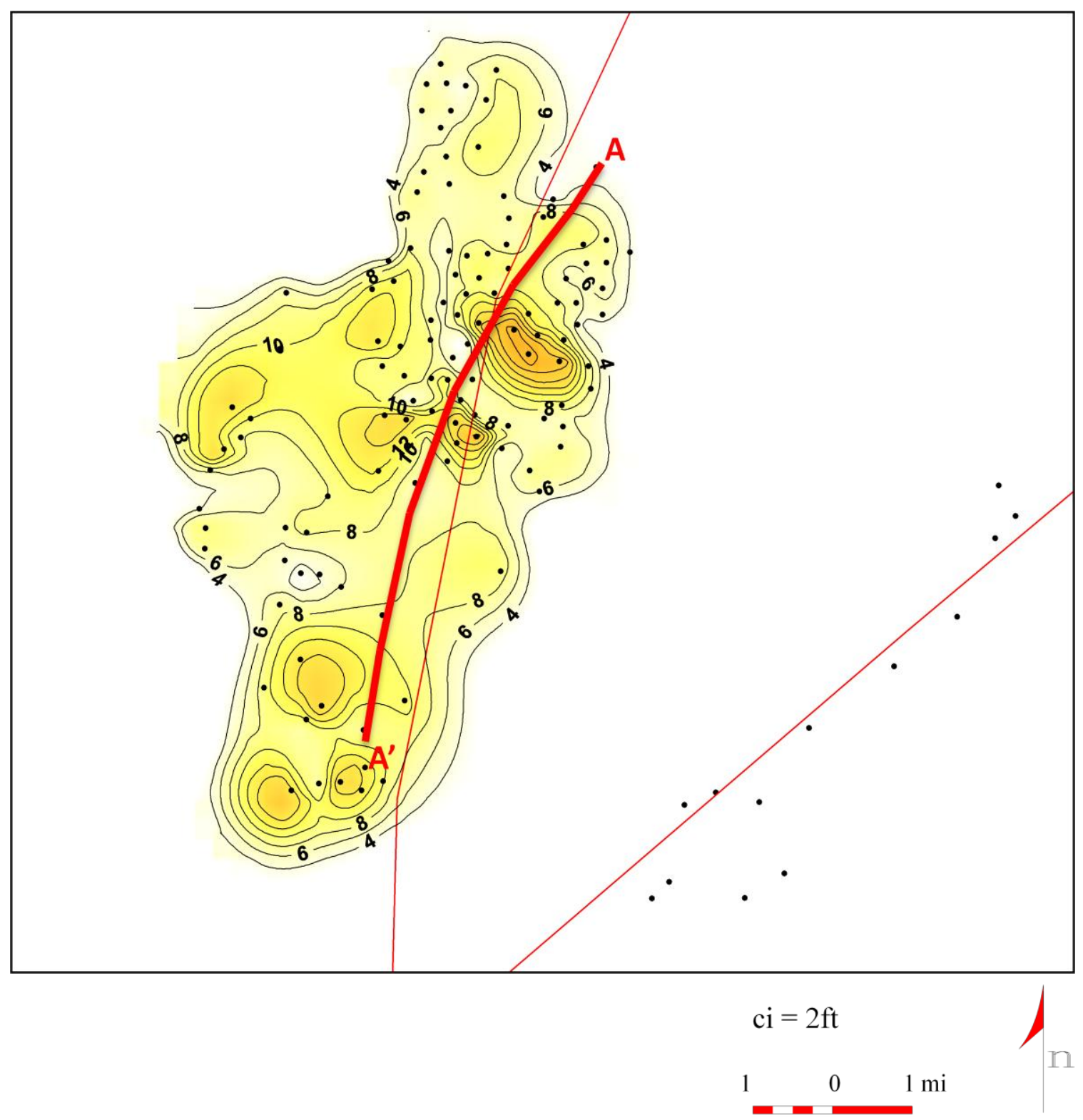

Figure 21. Net sandstone map of the upper Speechley sequence. Orange area indicates thick sandstone sections decreasing to the white areas indicating thinner sandstone sections. Cross section A-A' shown in Figure 22. 


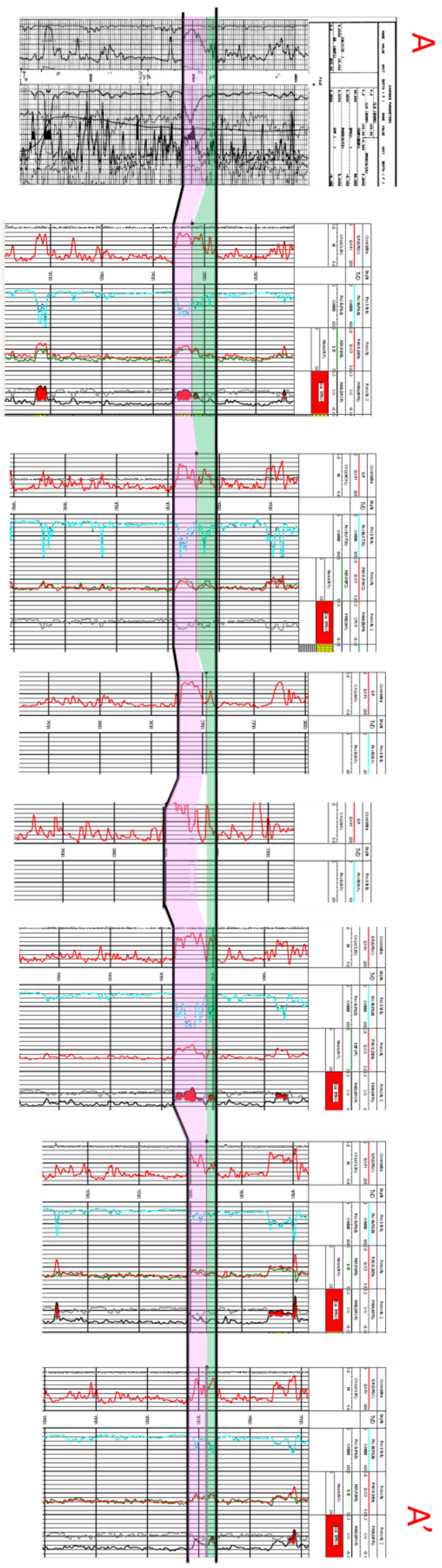

Figure 22. Stratigraphic cross section of the Speechley sandstone. The datum is the top of the Speechley unit. Pink shading highlights the lower sequence with API values less than a hundred. Green shading highlights the upper sequence with API values less than a hundred. 


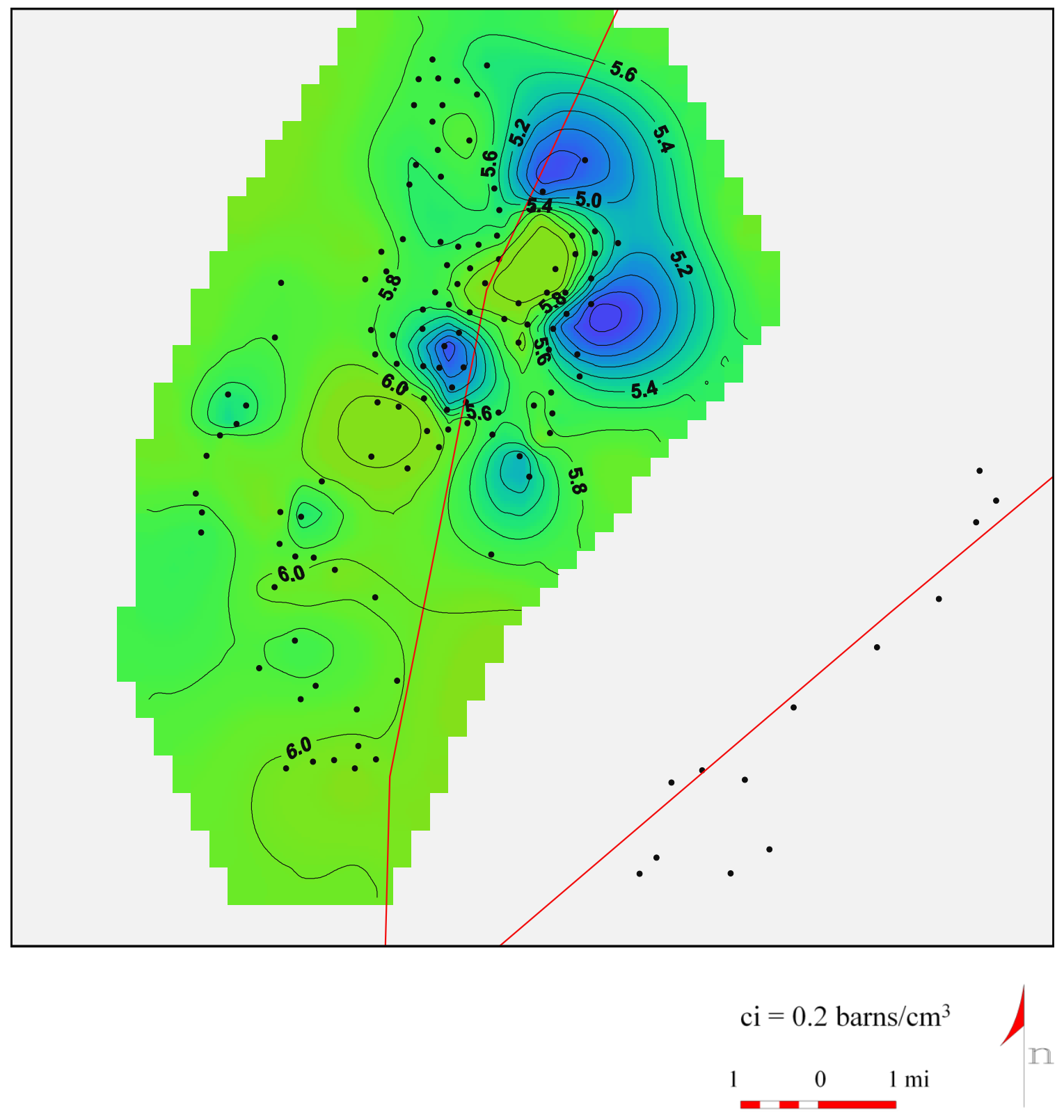

Figure 23. Umaa map of the lower Speechley sequence. Cool colors indicate low Umaa values suggesting quartz-rich rocks and warmer colors indicate higher Umaa values suggesting increased calcite or clay content. 


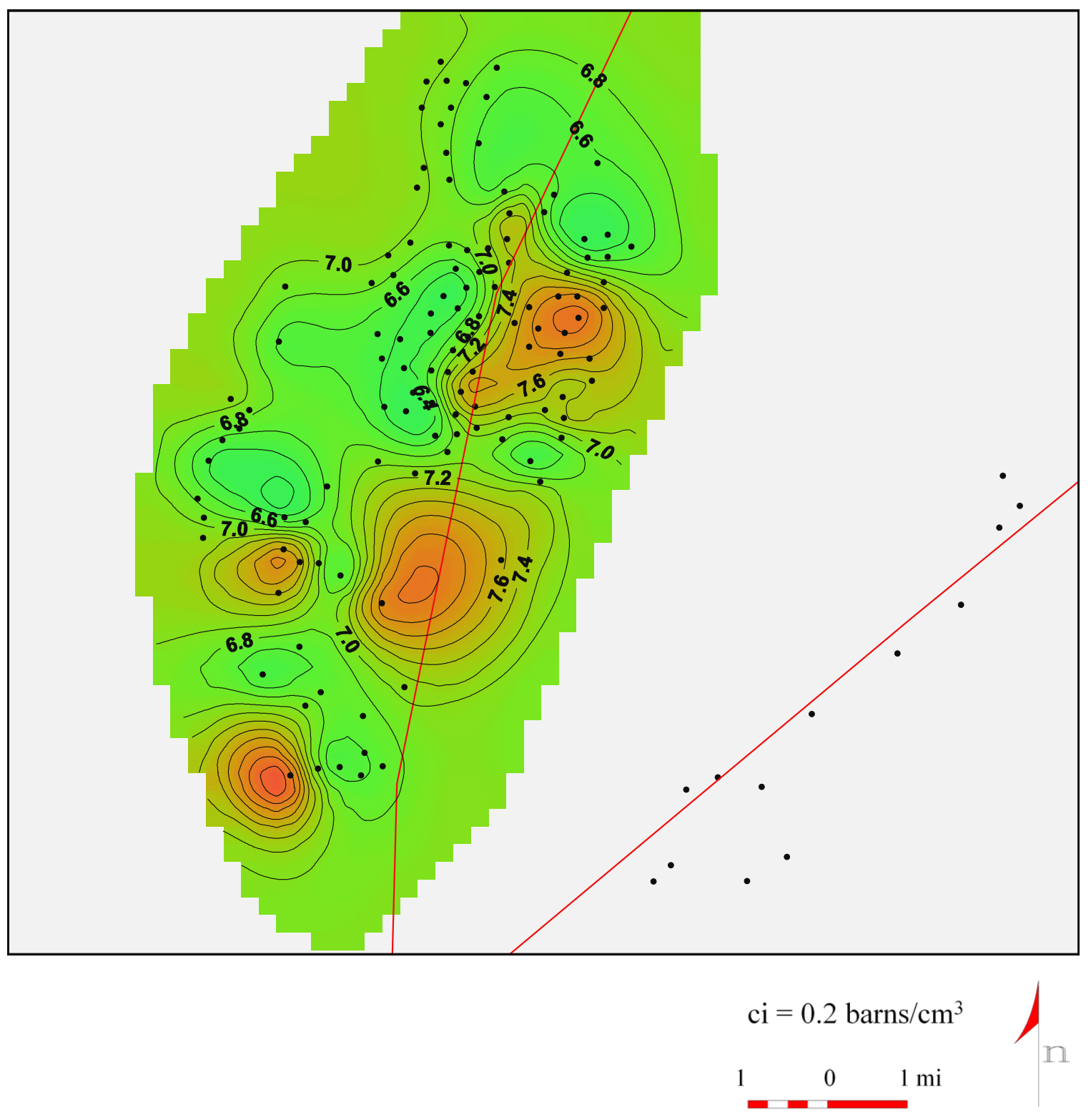

Figure 24. Umaa map of the upper Speechley sequence. Cool colors indicate low Umaa values suggesting quartz-rich rocks and warmer colors indicate higher Umaa values suggesting increased calcite or clay content. 


\section{Speechley Sandstone Unit Interpretation}

There are significant variations in interpretation of the Speechley sandstone unit. Cotter and Driese (1998) identified a facies equivalent unit to the east (near the Appalachian structural front), and determined that the depositional environment was fluvial in origin. In north central West Virginia, approximately fifty miles (eighty $\mathrm{km}$ ) to the south, the Speechley sandstone unit has been interpreted as shallow marine channel deposit that meandered across a gentle slope (Horsey, 1978). Approximately fifty miles (eighty $\mathrm{km}$ ) north of the study area, this sandstone unit was interpreted as deposited in a distributary channel on the delta plain, which was then reworked during a high stand (Johnson, 2008).

Within my study area the Speechley sandstone unit is interpreted as an estuarine-valley fill. This interpretation is supported by the following: 1) the net sand map shows laterally extensive and thick sandstone for both the lower and upper sequences; 2) the logs and cross sections show a lower sandstone sequence with a sharp basal contact that is down cutting and a top sequence which is separated by a flooding surface; and 3) the Umaa map shows high quartz content with very little clay and calcite material in the lower sequence with significantly higher calcite in the upper sequence. This finding suggests that the lower sequence was supplied by high energy fluvial sources, while the upper sequence was influenced by marine processes.

The lower Speechley sequence is interpreted as deposited as an estuarine-valley fill. The down cutting base of this sequence suggests there was fluvial erosion at the base of the paleovalley during a low stand. The blocky log signature with low Umaa values indicates that quartz-rich fluvial sediments then filled the paleovalley. The upper Speechley sequence has varying log signatures that make it difficult to interpret; 
however, the shale break at the base suggests a possible transgression, and the higher Umaa values suggest a significant amount of calcite. The RHOmaa-Umaa plot shown previously, also indicates an increase in calcite which is possibly from a marine source (Figure 13). During a transgressive event, the fluvial deposits of the lower Speechley sequence are overlain by estuarine deposits marked by a flooding surface (Dalrymple et al., 1992). As the estuary continues to migrate landward, the upper portion of the transgressive event will be removed by shoreface or tidal erosion (Figure 25).

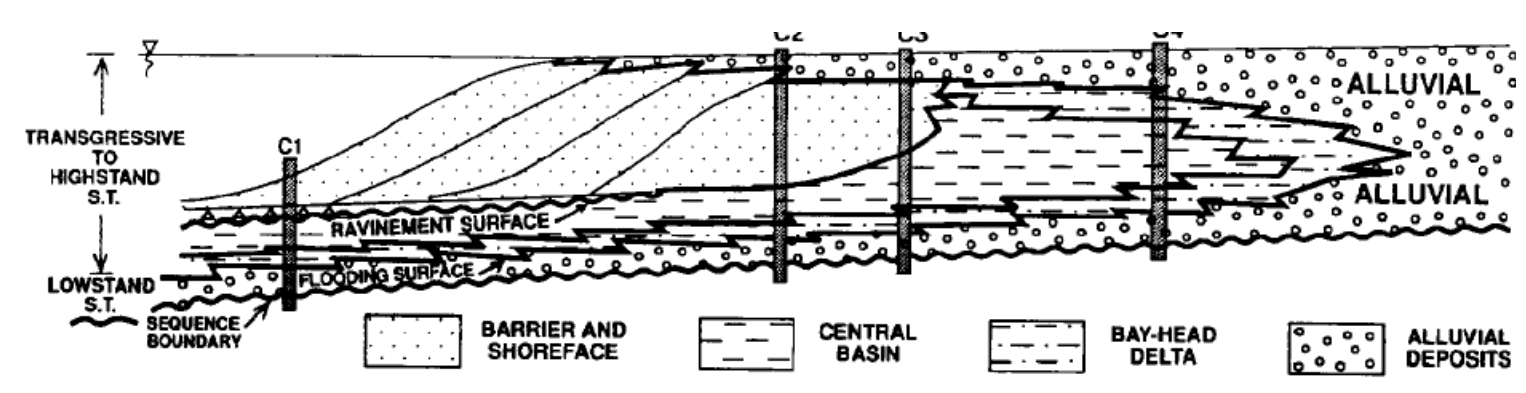

Figure 25. Distribution of facies in a transgressive estuary (modified from Dalrymple and others, 1992). 


\section{Speechley Stray Sandstone Unit Description}

The Speechley Stray sandstone unit for this study is defined as the fining upward sandstone unit on the top of Speechley unit (Figure 9). In the study area, the sub-sea depth of the Speechley Stray unit ranges from 2700 to 3300 feet $(820$ to $1000 \mathrm{~m})$. Across the study area, this unit has a bell shaped log signature with massive sandstone at the base (Figure 26). The sandstone is bound by a sharp basal contact with a fining upward sequence. Also, the fining upward sequence appears to have different sandstone bedsets. These bedsets thin upward along with shale content that increases towards the top (Figure 26 and 30).

The net sandstone map of the Speechley Stray is an aerially extensive sandstone unit that is thickest on the western limb of the anticline. There are distinct lobes of sand but the overall trend is north to south (Figure 27). The Speechley Stray unit has an average thickness of 7.8 feet $(2.4 \mathrm{~m})$, and a maximum thickness of 26 feet $(7.9 \mathrm{~m})$ (attribute statistics calculated using Prizim $^{\mathrm{tm}}$ ). In cross section, the Speechley Stray can be seen with a blocky base and fining upward sequence (Figure 28).

The Speechley Stray Umaa map shows that the lowest values coincide with the thickest section of the Speechley Stray (Figure 29). These values increase rapidly towards the edges of the sandstone. Many of the thickest sections of Speechley Stray have Umaa values of around six. These Umaa values are slightly higher than what was seen previously indicating high quartz content with some clay material. 

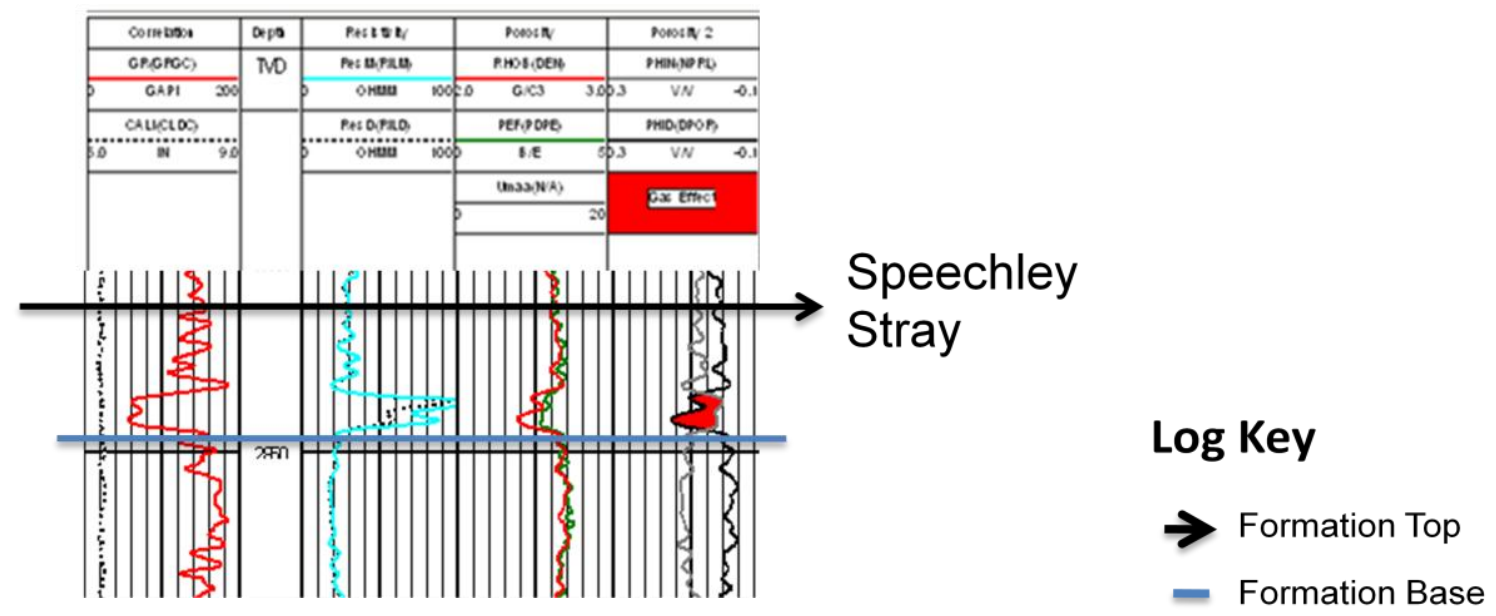

Figure 26. Gamma ray log signature that characterizes the Speechley Stray sandstone unit. 


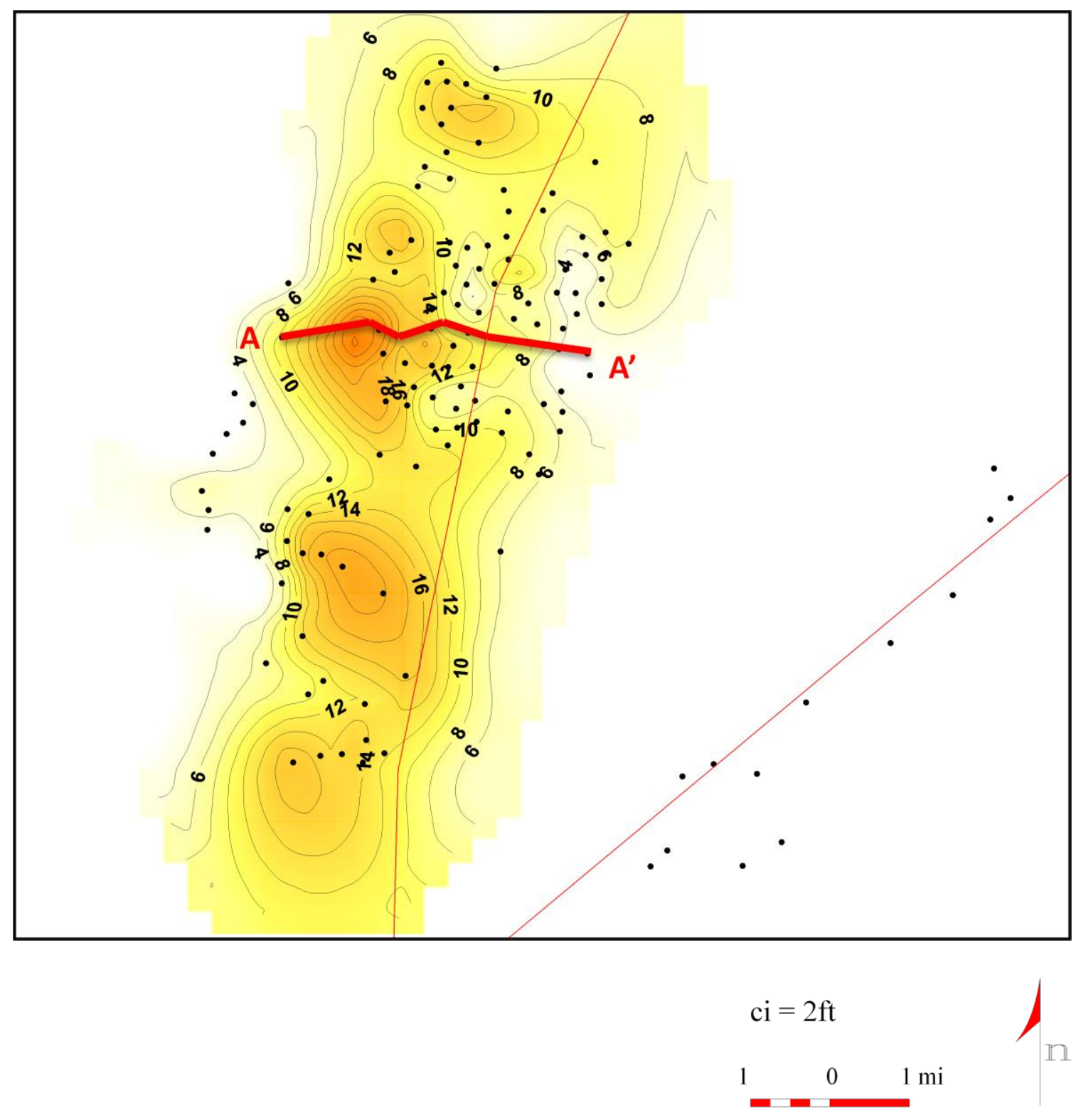

Figure 27. Speechley Stray net sandstone map. Orange area indicates thick sandstone sections decreasing to the white areas indicating thinner sandstone sections. Cross section A-A' shown in Figure 29. 


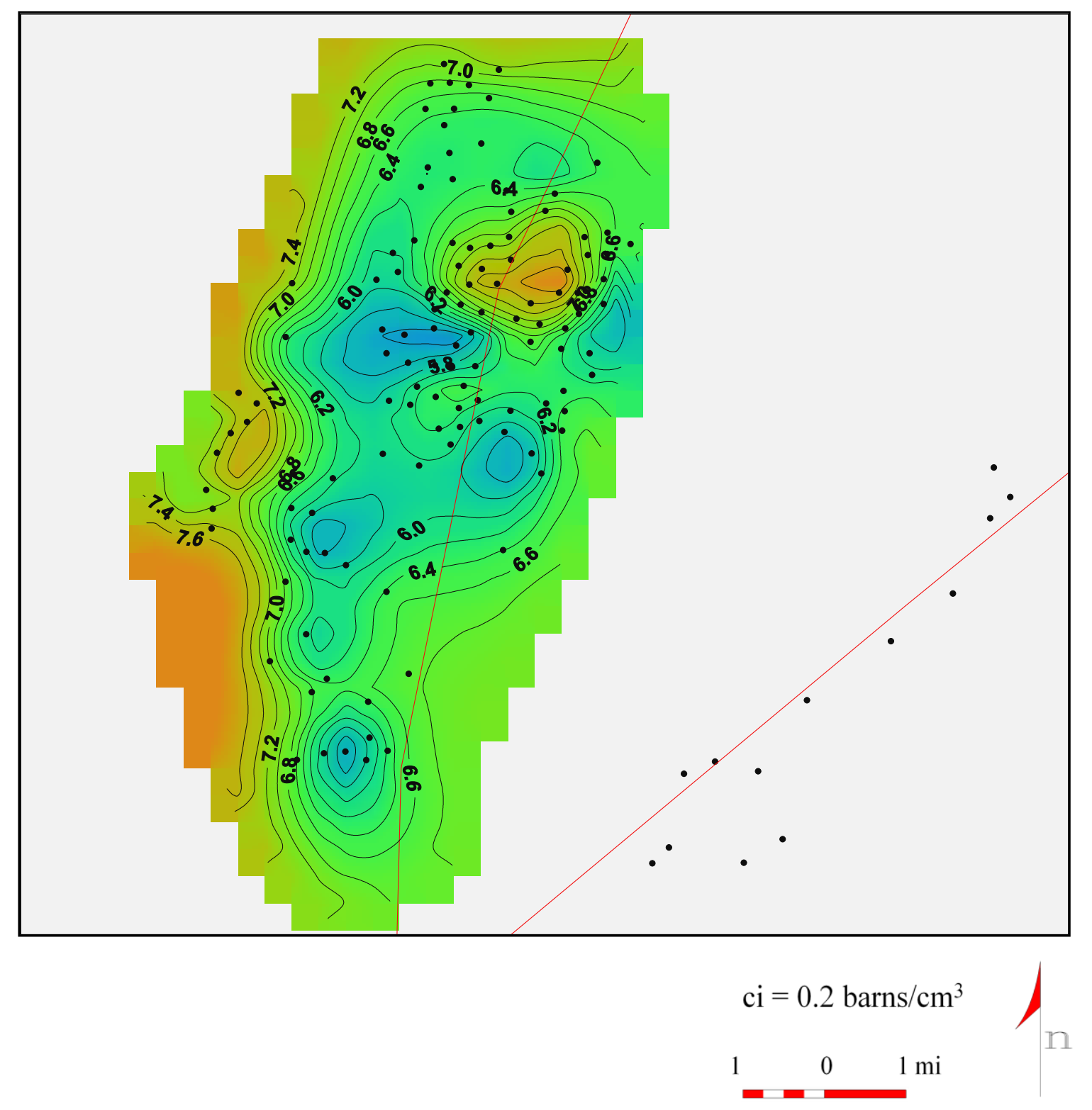

Figure 28. Speechley Stray Umaa map. Cool colors indicate low Umaa values suggesting quartz-rich rocks and warmer colors indicate higher Umaa values suggesting increased calcite or clay content. 


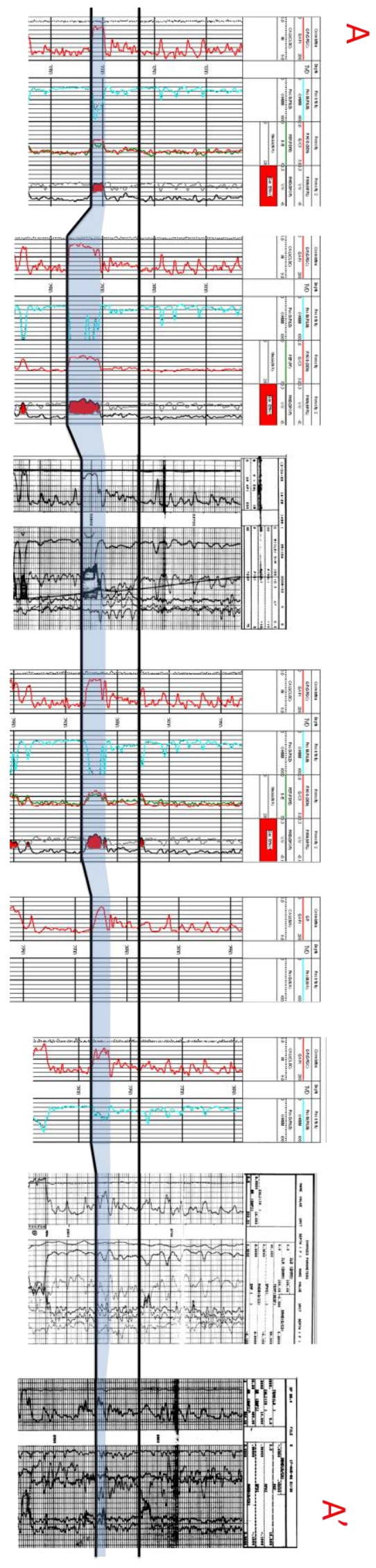

Figure 29. Stratigraphic cross section of the Speechley Stray sandstone. The datum is the top of the Speechley Stray unit. Blue shading highlights where the API value is less than a hundred. 


\section{Speechley Stray Sandstone Unit Interpretation}

The Speechley Stray sandstone unit is interpreted as a lower prograding delta front. This interpretation is supported by the following: 1) the net sand map shows laterally extensive and thick sandstone; 2) the logs and cross sections show a blocky base, fining upward sequence, and thinning upward bedset; and 3) the Umaa map shows quartz content with increased amounts of clay. This interpretation is consistent with other published work. Cotter and Driese (1998) interpreted the Speechley Stray sandstone as an alluvial facies, and according to Boswell (1988), the Speechley Stray unit marks one of the final major progradations of the Catskill delta complex.

In the study area, the Speechley Stray unit is interpreted as a sandstone deposited along a muddy shoreline during progradation of the delta front. The blocky base observed in the logs and cross sections indicate distributary channels of the delta front. Distributary channels are observed in the Umaa map as a quartz rich sandstone with channel morphology The fining upward sequence and thinning upward bedsets observed in cross section are characteristic of a parasequence (Figure 30). A parasequence is defined as a conformable succession of genetically related beds bound by marine flooding surfaces (VanWagoner et al., 1990). According to Van Wagoner and others (1990), most siliciclastic parasequences are progradational. The bedsets were likely sourced from river mouths along shorelines. As the bedsets got progressively younger, deposition of distal toes migrated basinward. A typical muddy shoreline parasequence would start with cross-bedded subtidal sandstone, continue with intertidal mudstone and rippled sandstone, and be capped with supratidal bioturbated mudstone (Holland, 2008). 


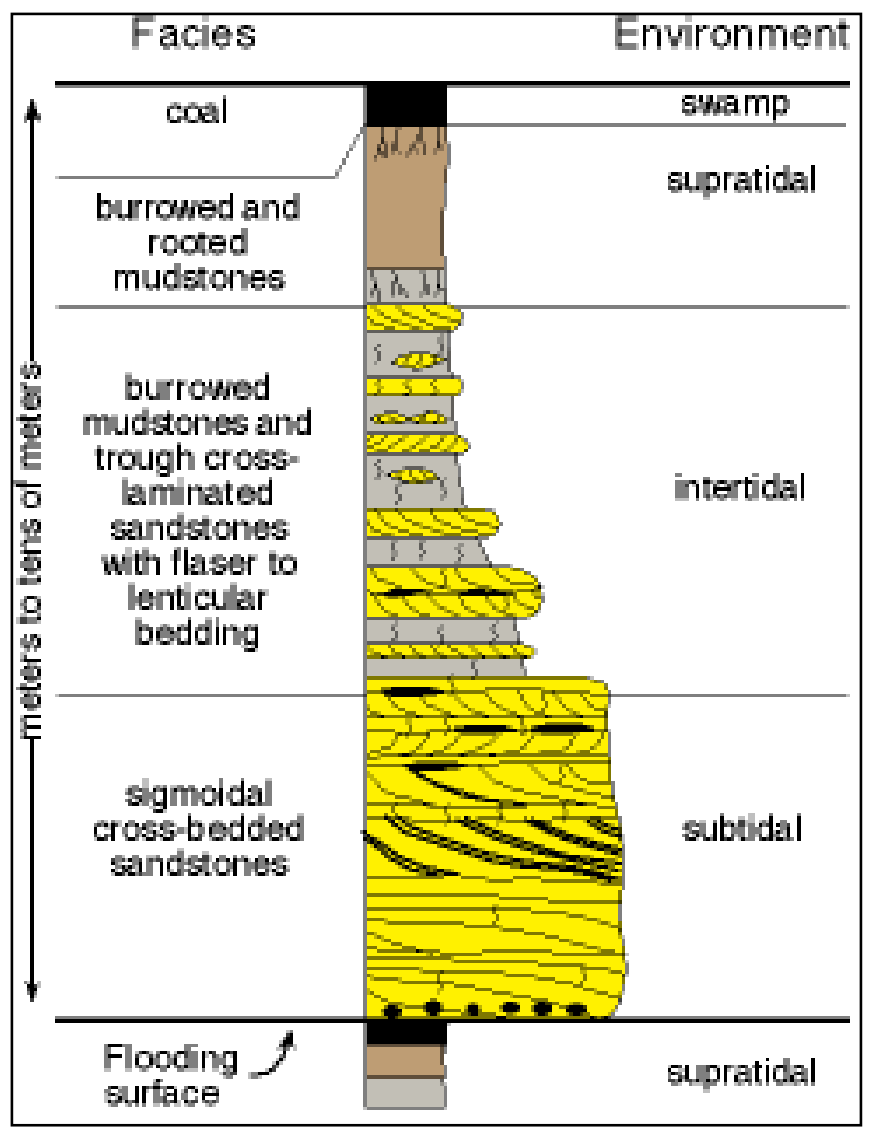

Figure 30. A parasequence deposited on a muddy siliciclastic shoreline with upward thinning bedsets and shallowing upward (modified from Holland, 2008). 


\title{
DESCRIPTION AND INTERPRETATION OF THE VENANGO GROUP SANDSTONE UNITS
}

\author{
Bayard Sandstone Unit Description
}

The Bayard sandstone unit for this study is defined as the interval from the bottom of the Fifth sandstone unit to the top of the Elizabeth sandstone unit. For this study the Bayard was broken down into two sequences that could be recognized across the study area. The upper and lower sequences are divided by a distinct shale break. In the study area, the sub-sea depth of the Bayard unit ranges from 2100 to 2700 feet (640 to $820 \mathrm{~m})$.

The lower sequence has a modified bell and funnel log signature that is fining upward with sharp contacts on top and bottom (Figure 31). This log response is commonly associated with tidal point bars, channel fills, or fluvial sandstone units (Wilson and Nanz, 1959). The net sandstone map of the lower sequence shows an aerially extensive sandstone unit that trends north to south which is separated by a thin (Figure 32). The lower sequence has an average thickness of 5.4 feet $(1.6 \mathrm{~m})$ and a maximum thickness of twenty feet $(6 \mathrm{~m})$ (attribute statistics calculated using Prizim ${ }^{\mathrm{tm}}$ ). In cross section, the lower sequence pinches out in the center of the study area in a north to south trend (Figure 34). The thickest section of the bottom unit is observed to the north and south farthest from the pinchout. The lower sequence Umaa map shows that the lowest values coincide with the thickest section of sandstone. These values increase rapidly towards the pinchout indicating an increase of calcite material relative to quartz. Umaa values range from 5.4 to 9.2 which is the largest range seen in any previous Umaa map (Figure 35). 
The upper sequence has a funnel and symmetrical log signature. The prominent log signature is a coarsening upward sequence that transitions into a fining upward sequence (Figure 31). This log response is commonly associated with reworked point bars and regressive to transgressive events (Wilson and Nanz, 1959). The net sandstone map of the upper sequence shows a more irregular distribution with sandstone lobes that trend east to west across the Grapeville anticline (Figure 33). There are also thins in the upper sequence that trend east to west. The upper sequence has an average thickness of 4.9 feet $(1.5 \mathrm{~m})$ and a maximum thickness of twenty feet (six m) (attribute statistics calculated using Prizim ${ }^{\text {tm }}$ ). In cross section, the upper sequence pinches out in the center of the study area in a north to south trend (Figure 34). Reciprocal sedimentation is also observed in cross section. Thicker sections of the upper sequence correspond to thinner sections of the lower sequence, and vice versa. The upper sequence Umaa map shows a trend that is more ambiguous. Low Umaa values correlate to both thin and thick sandstone sections. Umaa values range from 5.0 to 7.6. The highest Umaa values occur where the upper sequence is thinnest (Figure 36), and indicate an increase in calcite content. 


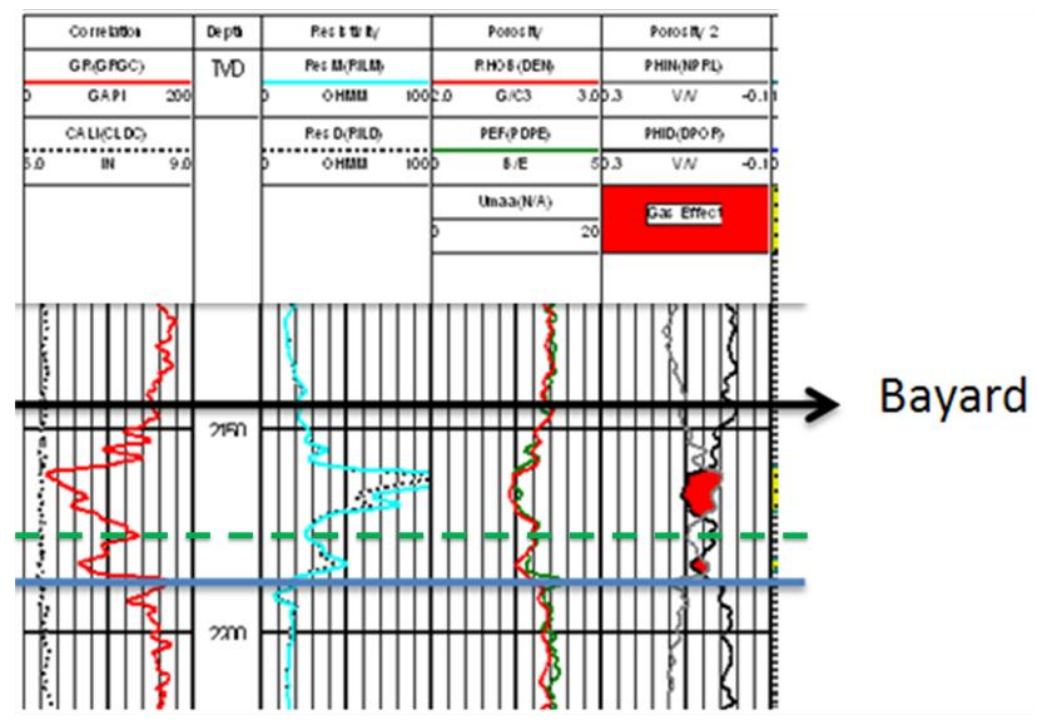

Log Key
$\Rightarrow$ Formation Top
$=$ Formation Base
- - Sequence Division

Figure 31. Gamma ray log signature that characterizes the Bayard sandstone unit. 


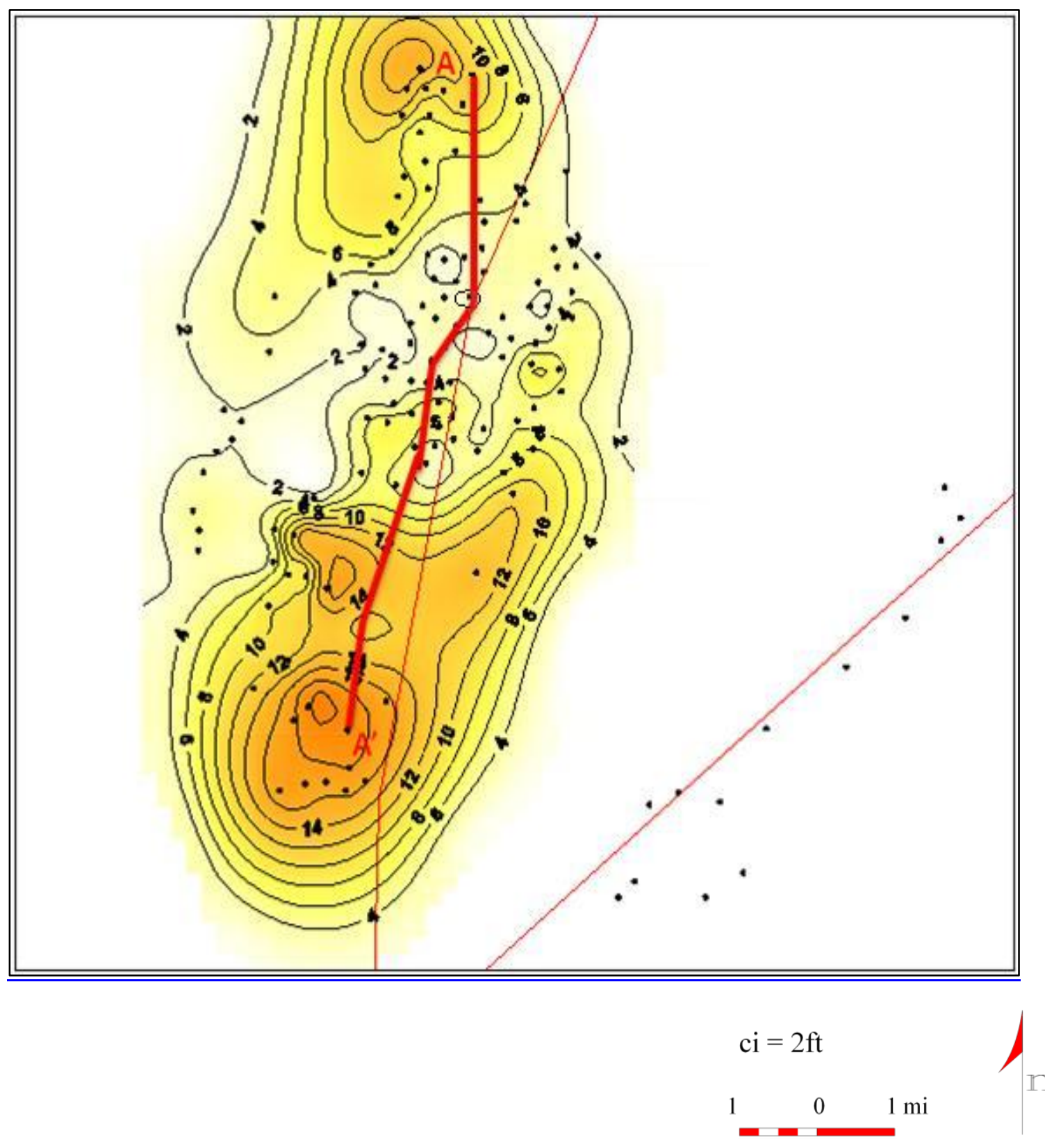

Figure 32. Bayard lower sequence net sandstone map. Orange area indicates thick sandstone sections decreasing to the white areas indicating thinner sandstone sections. Cross section A-A' shown in Figure 34. 


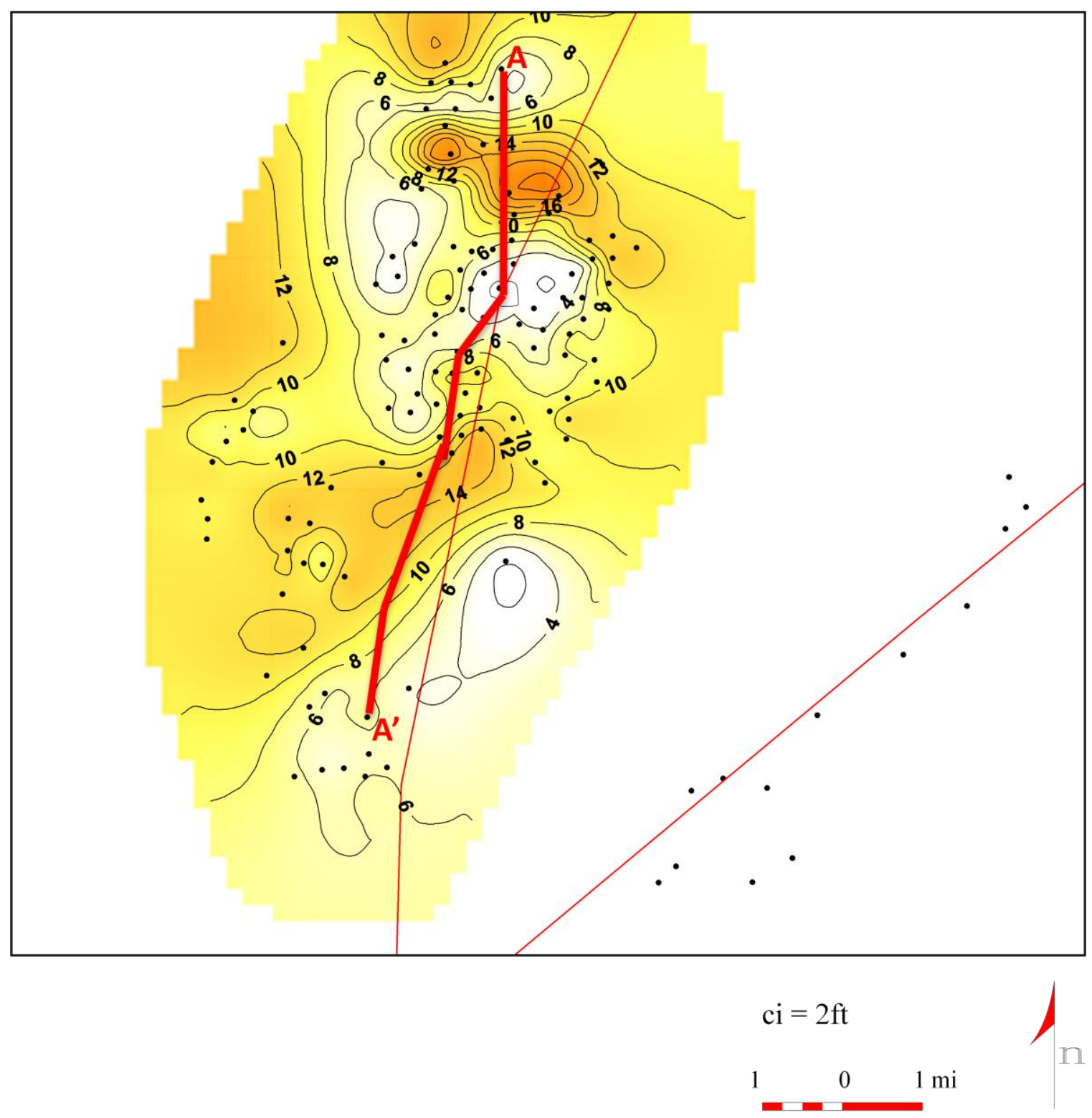

Figure 33. Bayard upper sequence net sandstone map. Orange area indicates thick sandstone sections decreasing to the white areas indicating thinner sandstone sections. Cross section A-A' shown in Figure 34. 


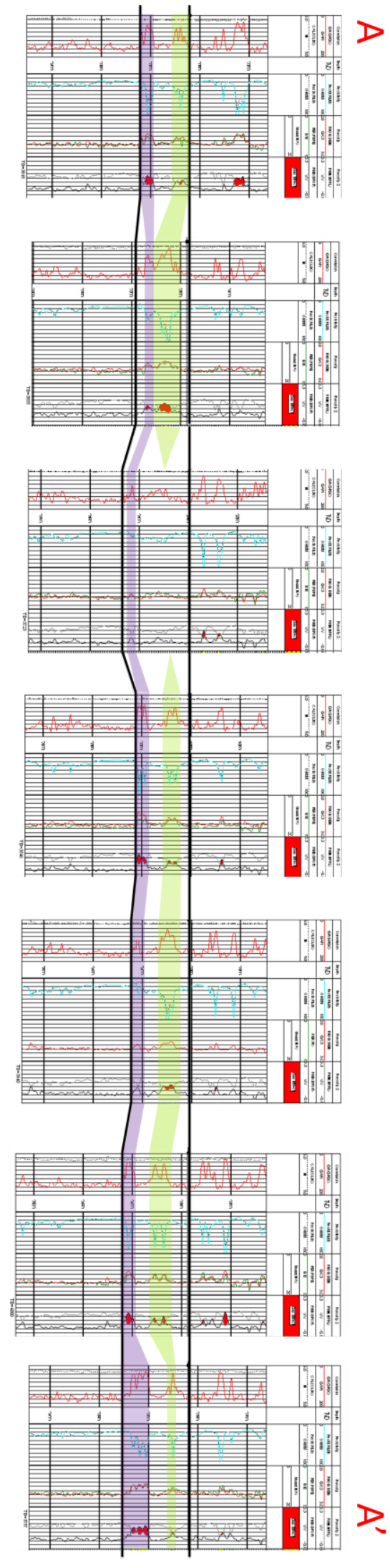

Figure 34. Stratigraphic cross section of the Bayard sandstone. The datum is the top of the Bayard unit. Purple shading highlights the lower sequence with API values less than a hundred. Green shading highlights the upper sequence with API values less than a hundred. 


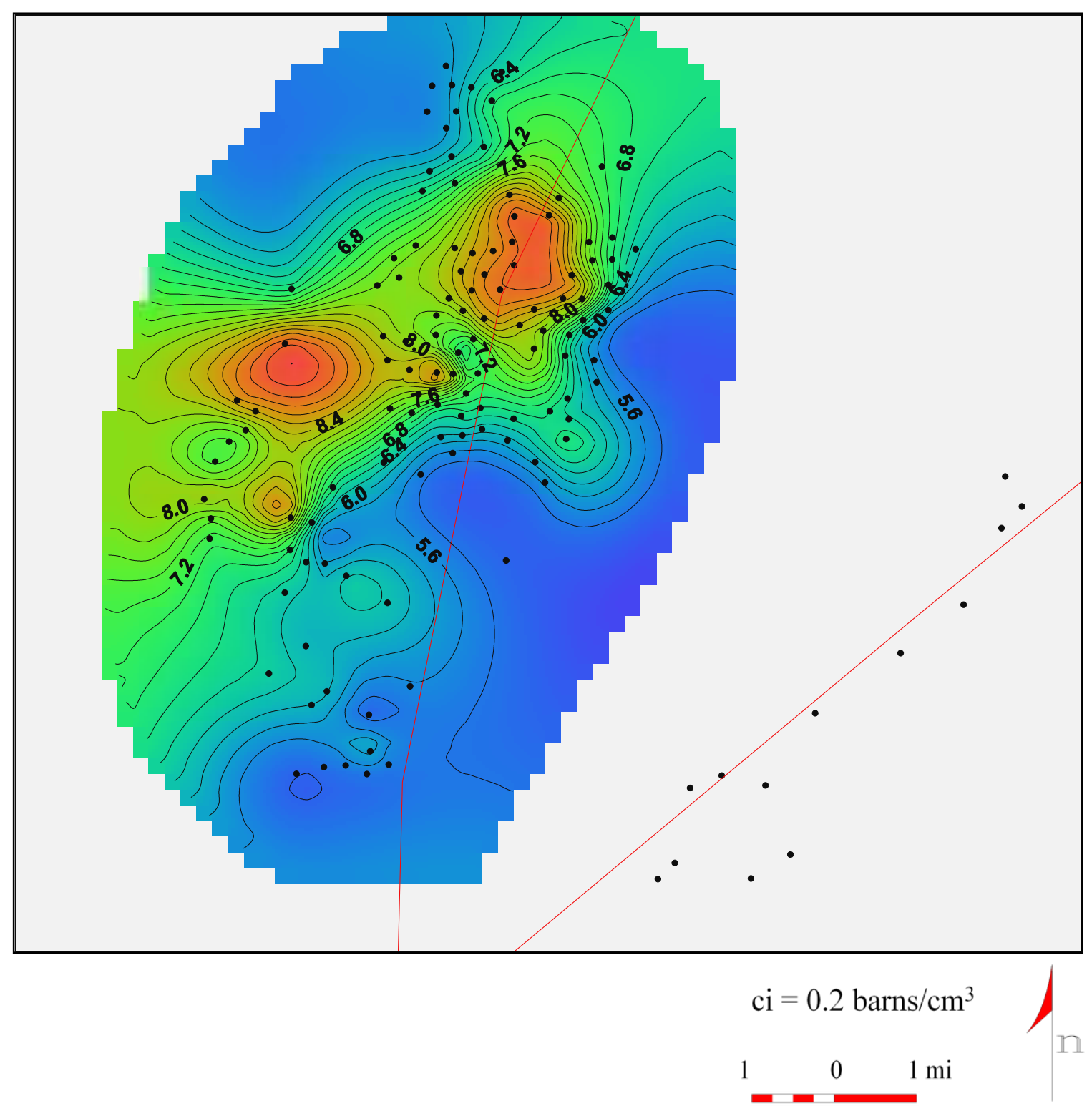

Figure 35. Bayard lower sequence Umaa map. Cool colors indicate low Umaa values suggesting quartz-rich rocks and warmer colors indicate higher Umaa values suggesting increased calcite or clay content. 


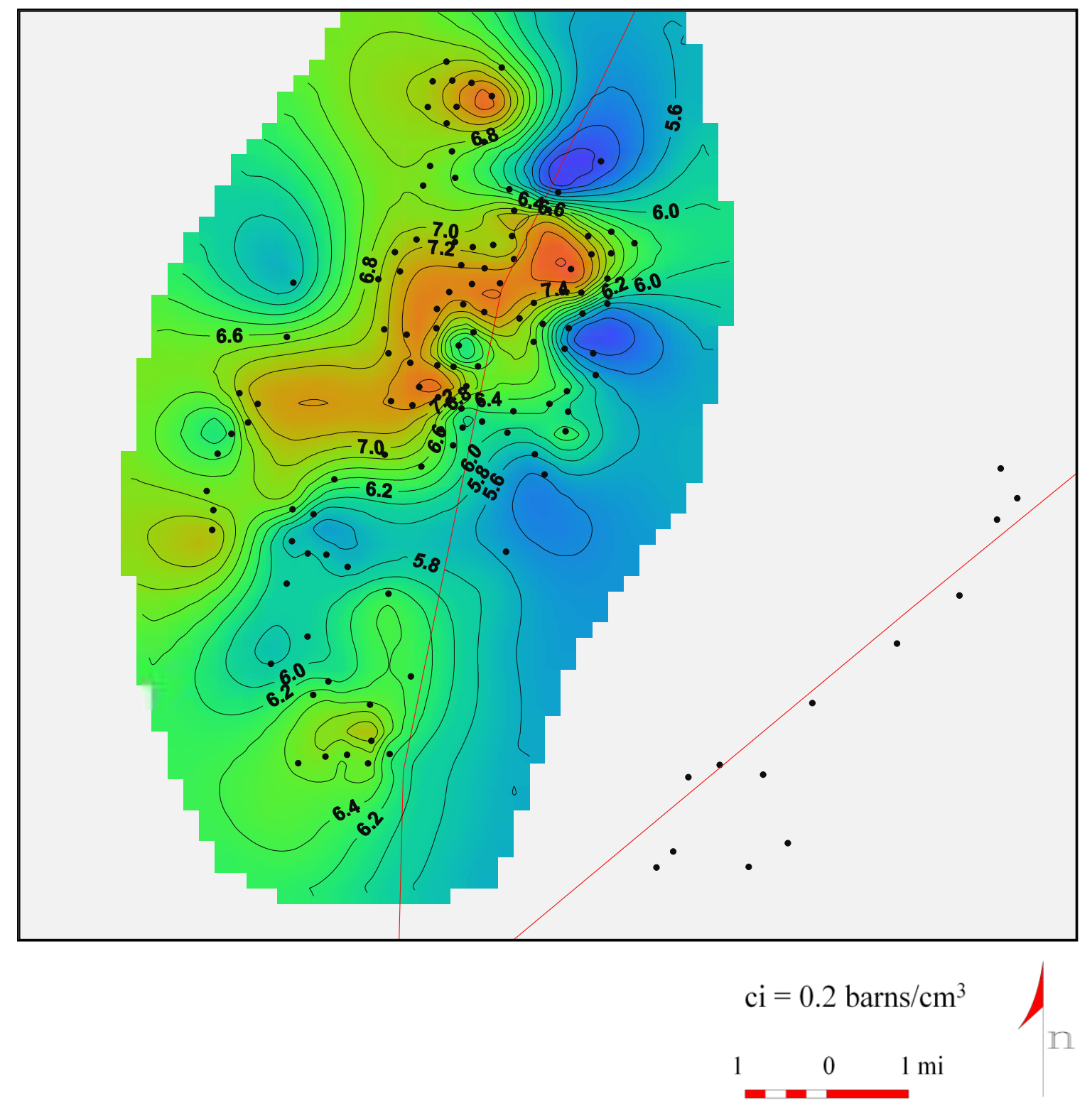

Figure 36. Bayard upper sequence Umaa map. Cool colors indicate low Umaa values suggesting quartz-rich rocks and warmer colors indicate higher Umaa values suggesting increased calcite or clay content. 


\section{Bayard Sandstone Unit Interpretation}

The lower sandstone sequence is interpreted as an offshore bar deposit. This interpretation is supported by the following: 1) the net sand map shows thick sandstone sections that are separated by an area with high calcite content; 2) the logs and cross sections show a modified funnel and bell shaped sandstone unit with sharp bottom and top contacts that are indicative of a bar deposit; and 3) the Umaa map shows higher quartz content where the thickest sandstone lobes are located with a significant amount of calcite.

The upper sandstone sequence is also interpreted as an offshore bar deposit. This interpretation is supported by the following: 1) the net sand map shows irregularly distributed sandstone sections; 2) the logs and cross sections show a symmetrical signature with gradual bottom and top contacts typical in offshore bars; and 3) the Umaa map shows a mixture of high and low Umaa values where the thickest sandstone lobes are located with a significant amount of calcite material.

The lower sequence was likely deposited in a relatively high energy environment The clean sediment with significant amount of calcite is typical in a marine deposit such as an offshore bar. The thin section in the center of the study area with high Umaa values indicates a thin between bars that is high in calcite material and marine sourced. The modified log appearance and sharp top contact suggests the bar was reworked and possible eroded by wave action. This interpretation contradicts the work completed by Peace (1988). He interpreted the lower Bayard Sandstone as fluvial deltaic sandstone deposited along a fluvial dominated shoreline. However, LaSota (1988) identified the lower Bayard sequence in the Sportsman Well just two miles north of the study area and interpreted it as a barrier bar deposit. 
The upper sequence was interpreted as an offshore bar depsoit similar to the lower sequence. The variation in Umaa values suggest the bar deposits are quartz-rich but have varying amounts of calcite derived from marine fossils. These sandstone lobes may be caused by spill-over from marine bars to the west. The symmetrical log signatures suggest these lobes of sand were later reworked by wave and tidal processes. LaSota (1988) interpreted the upper sequence in the Sportsman well and determined it was a barrier bar deposit as well. 


\section{Fifth Sandstone Unit Description}

The Fifth sandstone unit for this study is defined as the interval from the bottom

of the Fourth sandstone unit to the top of the Bayard unit. The Fifth sandstone is typically correlated as one unit, but for this study it was further broken down into four sequences. In the study area, the sub-sea depth of the Fifth sandstone unit ranges from 2000 to 2600 feet $(600$ to $800 \mathrm{~m})$.

Sequence one of the Fifth sandstone unit has a bell signature throughout the study area. The sandstone is bound by a sharp basal contact that is fining upward (Figure 37). The fining upward sequence indicates low shale content at the base, which increases towards the top. The net sandstone map of sequence one shows a distinct lobe of sand with channel morphology (Figure 38). This sequence has a meandering appearance that cuts across the Grapeville anticline and trends north to south.

Sequence one has an average thickness of 5.6 feet $(1.7 \mathrm{~m})$ and a maximum thickness of 24 feet $(7.3 \mathrm{~m})$ to the north (attribute statistics calculated using Prizim $\left.{ }^{\mathrm{tm}}\right)$. In cross section, sequence one is lenticular (Figure 42). This unit pinches out rapidly trending from east to west (Figure 16). In some cross sections, sequence one also appears to down cut. The sequence one Umaa map shows that the lowest values coincide with the distinct lobe of sandstone; however, Umaa values remain low across the study area. Umaa values range from 4.8 to 6.4. These are the lowest Umaa values when compared to previous sandstone units and indicate an extremely quartz-rich mineralogy (Figure 43).

Sequence two of the Fifth sandstone unit has a funnel signature throughout the study area (Figure 37). The sandstone is coarsening upward and is bound by a sharp top contact. The coarsening up sequence indicates high shale content at the base which 
decreases upward. The net sandstone map of sequence two shows an aerially extensive sandstone (Figure 39). It extends over the Grapeville anticline and trends north to south. The sandstone sequence is thickest on the east and thins to the west, and the thick of the sequence has shifted slightly westward when compared to sequence one. Sequence two is much thinner than sequence one with an average thickness of 3.2 feet (one $\mathrm{m}$ ) and a maximum thickness of nine feet $(2.7 \mathrm{~m})$ to the east of the anticline (attribute statistics calculated using Prizim ${ }^{\mathrm{tm}}$ ). In cross section, sequence two is laterally extensive. The sequence is thickest to the east and gradually thins out to the west (Figure 42). The Umaa map shows that the highest values coincide with the thickest sandstone. This relationship was seen previously in the upper sequence of the Speechley unit, which was marine sourced. Umaa values are also higher than what was observed previously (values range between 6.4 and 8.2). This occurrence indicates higher calcite content (Figure 44).

Sequence three of the Fifth sandstone unit has a funnel, symmetrical or spike log signature (Figure 37). The funnel signature is the most prevalent throughout the study area which has a coarsening upward sequence that is bound by a sharp top contact. The net sandstone map of sequence three shows an aerially extensive sandstone with some spotty distribution (Figure 40). It extends over the Grapeville anticline and trends north to south. Sequence three is thickest on the western limb of the anticline, and is located further westward when compared to sequence two. Sequence three is thinner than the lower sequences with an average thickness of 1.4 feet $(0.4 \mathrm{~m})$ and a maximum thickness of 5.2 feet $(1.6 \mathrm{~m})$ to the west of the anticline (attribute statistics calculated using Prizim $\left.{ }^{\mathrm{tm}}\right)$. In cross section, sequence three is extensive but lenticular. Sequence three pinches out to the east and thins out to the west (Figure 42). The Umaa map shows that the highest values coincide with the thickest sandstone (Figure 45). This 
relationship was also seen in the Fifth sandstone sequence two and the upper sequence of the Speechley unit. Umaa values range from 7.2 to 8.8. These are the highest Umaa values when compared to previous maps and likely indicate much more calcite material.

Sequence four of the Fifth sandstone unit has a symmetrical or serrated log signature (Figure 37). The symmetrical log signature is the most prevalent throughout the study area. This bow trend has a coarsening upward sequence which transitions into a fining upward sequence. The net sandstone map of sequence four shows an aerially extensive sandstone with spotty distribution (Figure 41). This sequence is the most extensive of the Fifth sandstone sequences. It extends over the Grapeville anticline and trends north to south. Sequence four is the thickest of the Fifth sandstone sequences with an average thickness of 6.1 feet $(1.8 \mathrm{~m})$ and a maximum thickness of 16 feet $(4.9$ m) (attribute statistics calculated using Prizim ${ }^{\mathrm{tm}}$ ). In cross section, sequence four is extensive and blankets the entire study area while maintaining thickness (Figure 42). The Umaa map shows that the lower values coincide with the thickest sandstone; however, the Umaa values remain relatively high across the study area (seven to eight) (Figure 46). These are the second highest Umaa values when compared to previous sandstone units and indicate a significant amount of calcite material. 

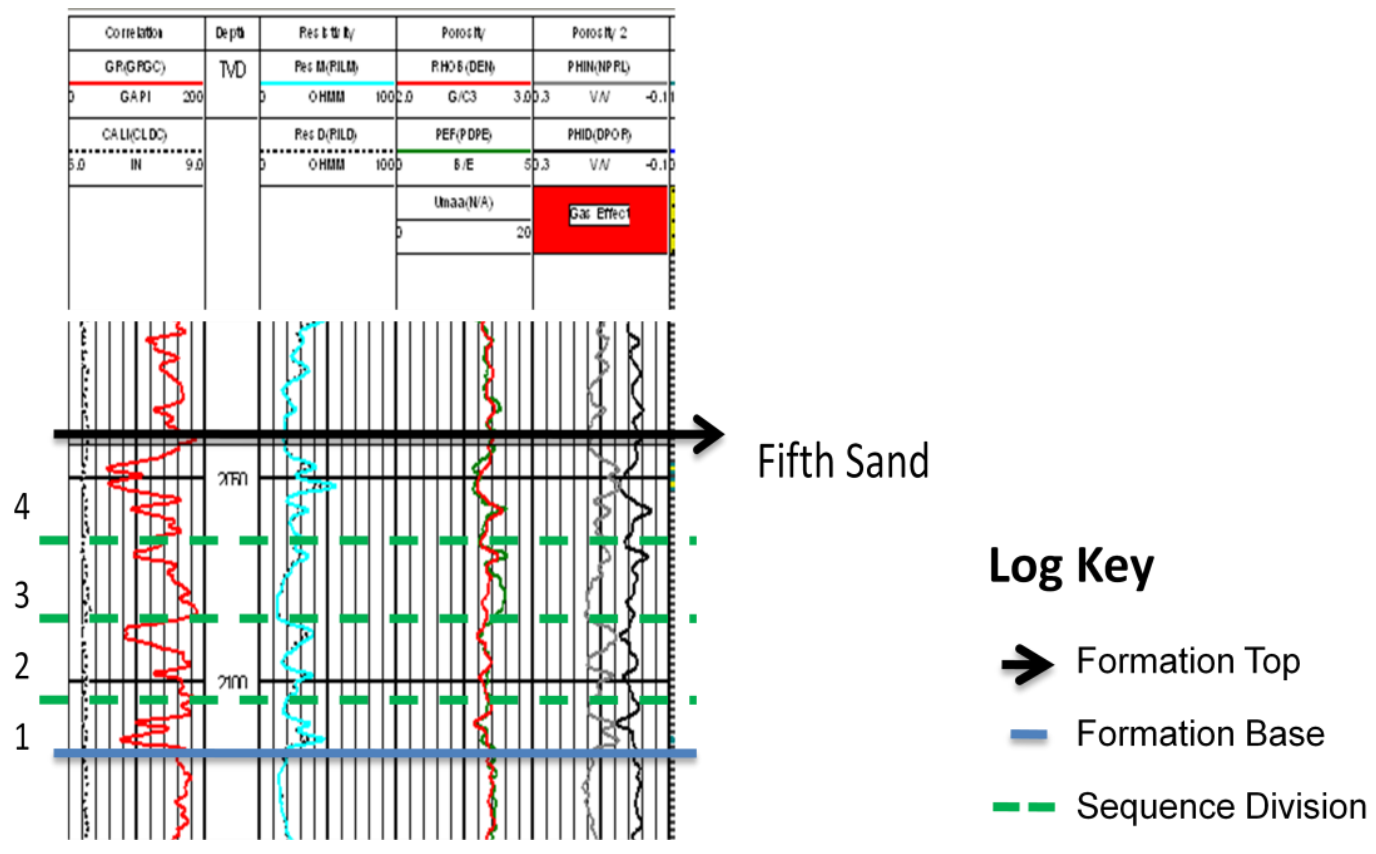

Figure 37. Gamma ray log signature that characterizes the Fifth sandstone unit. 


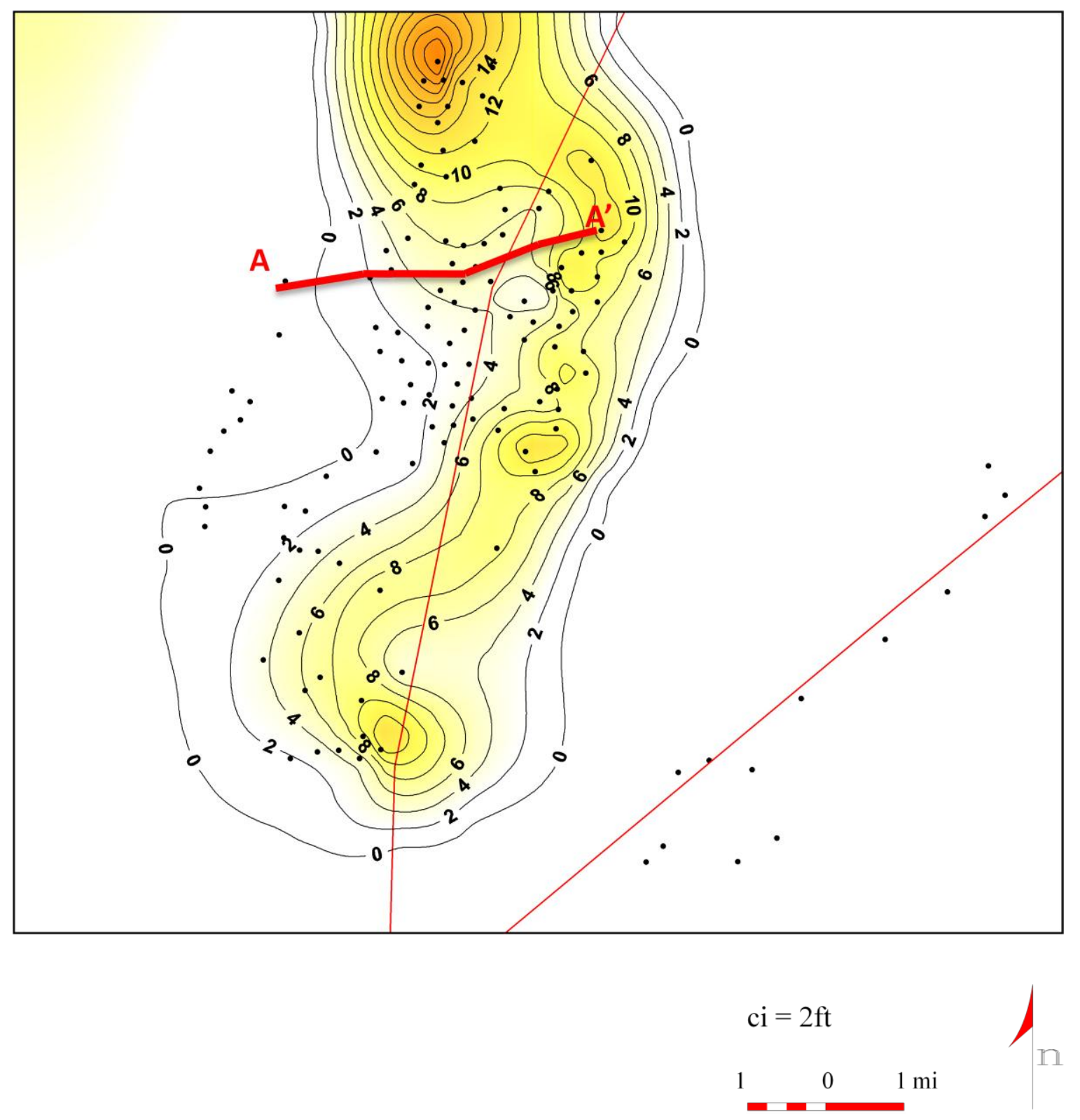

Figure 38. Fifth sandstone sequence one net sandstone map. Orange area indicates thick sandstone sections decreasing to the white areas indicating thinner sandstone sections. Cross section A-A' shown in Figure 42. 


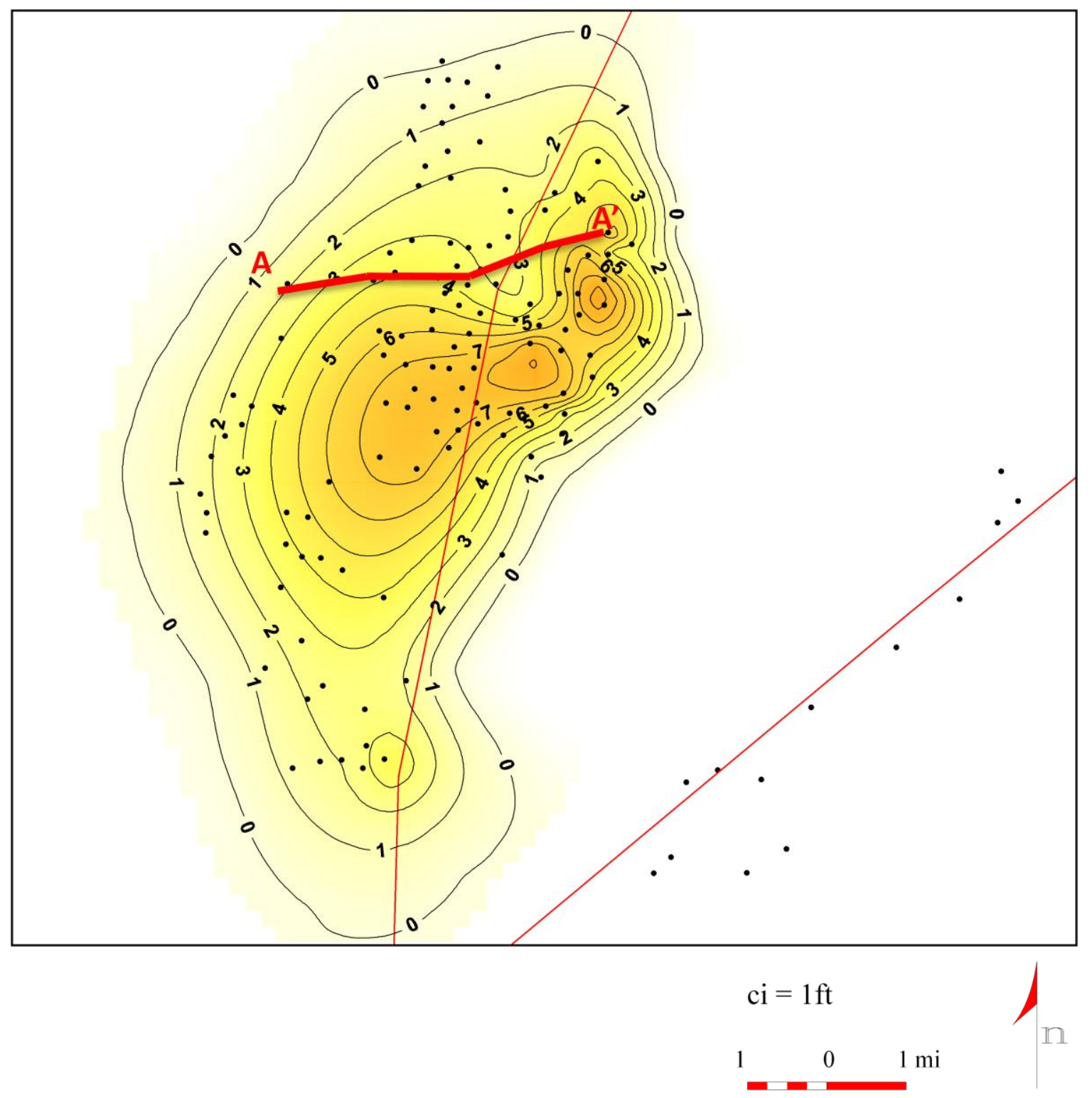

Figure 39. Fifth sandstone sequence two net sandstone map. Orange area indicates thick sandstone sections decreasing to the white areas indicating thinner sandstone sections. Cross section A-A' shown in Figure 42. 


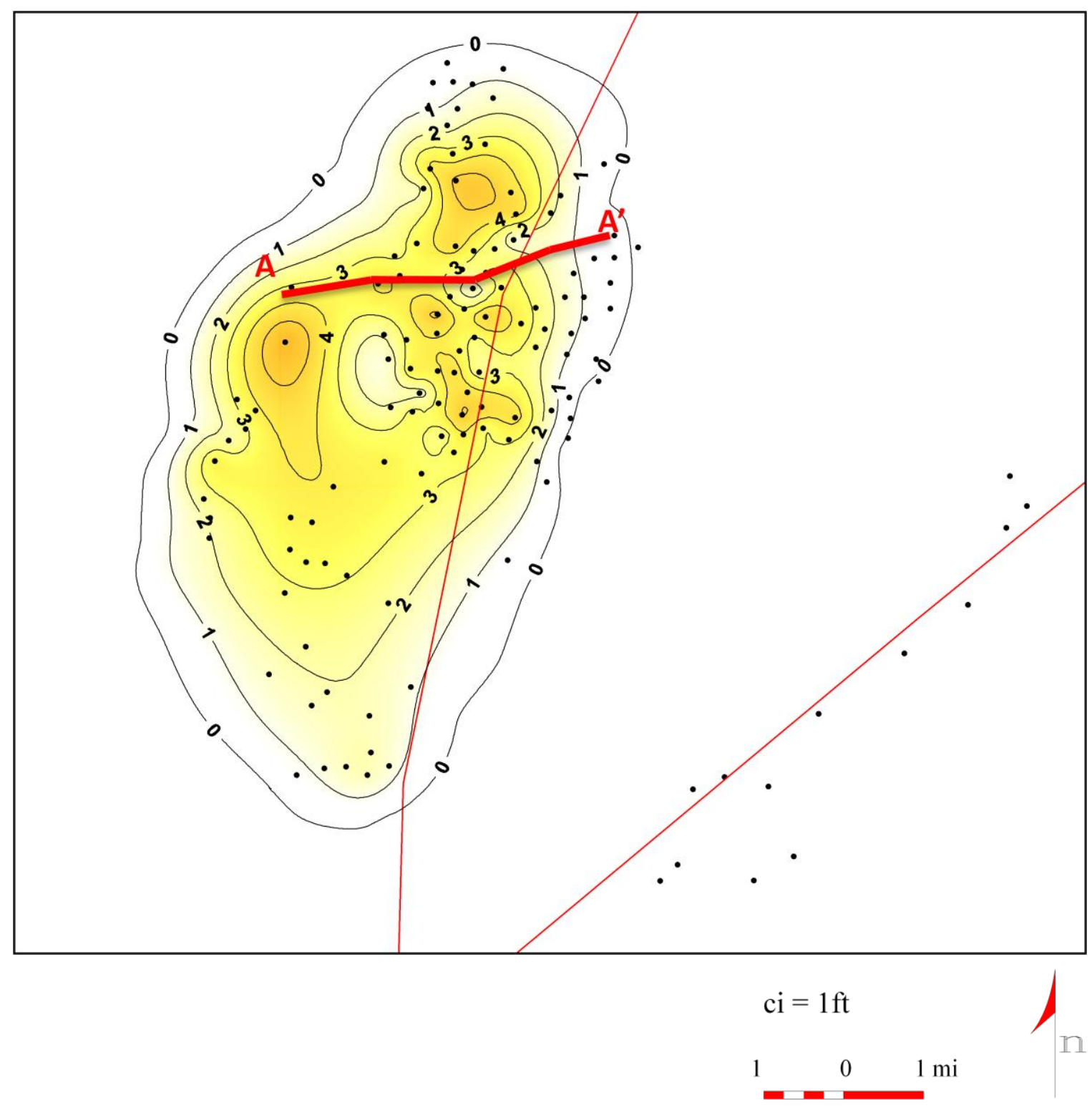

Figure 40. Fifth sandstone sequence three net sandstone map. Orange area indicates thick sandstone sections decreasing to the white areas indicating thinner sandstone sections. Cross section A-A' shown in Figure 42. 


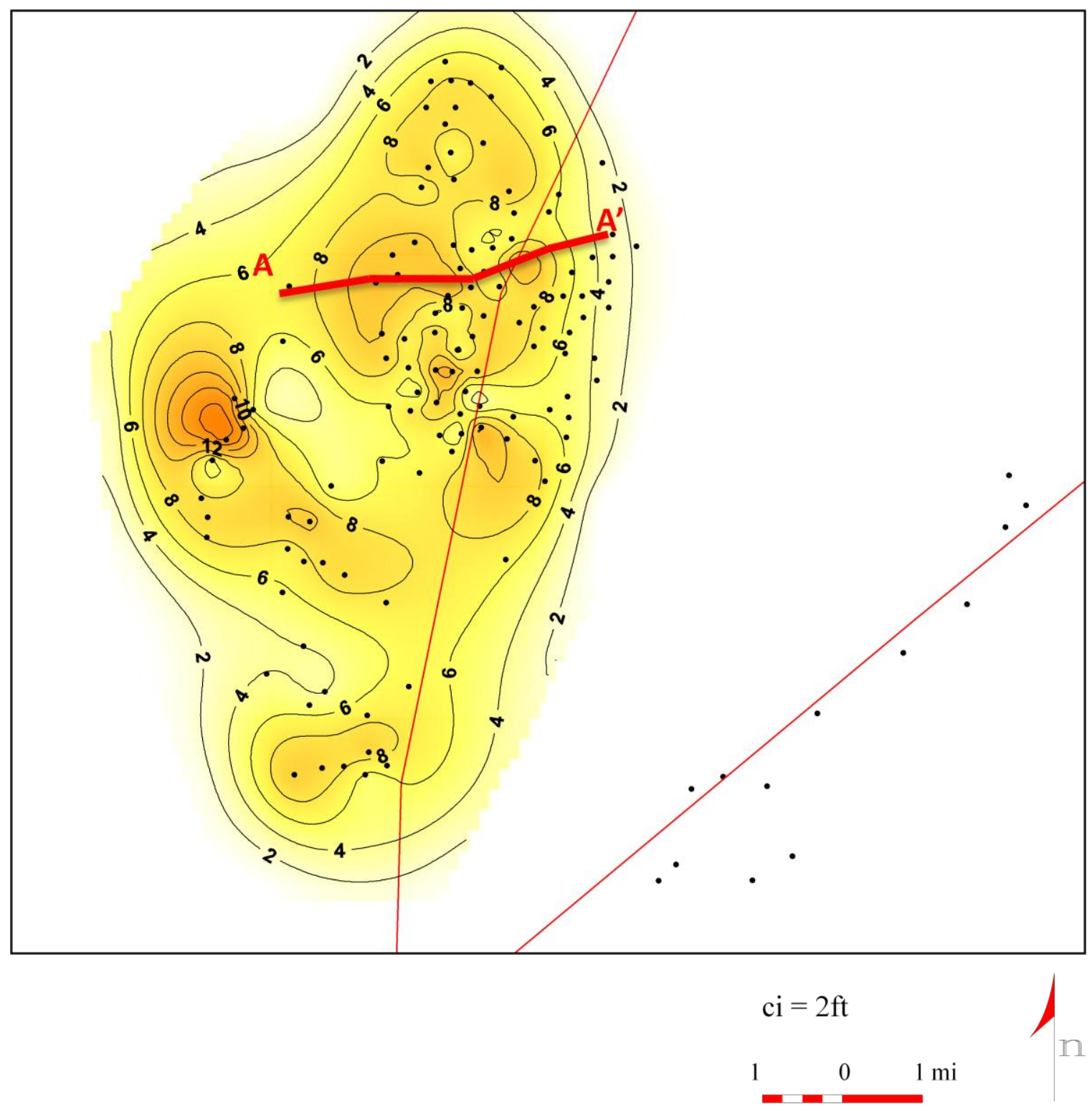

Figure 41. Fifth sandstone sequence four net sandstone map. Orange area indicates thick sandstone sections decreasing to the white areas indicating thinner sandstone sections. Cross section A-A' shown in Figure 42. 


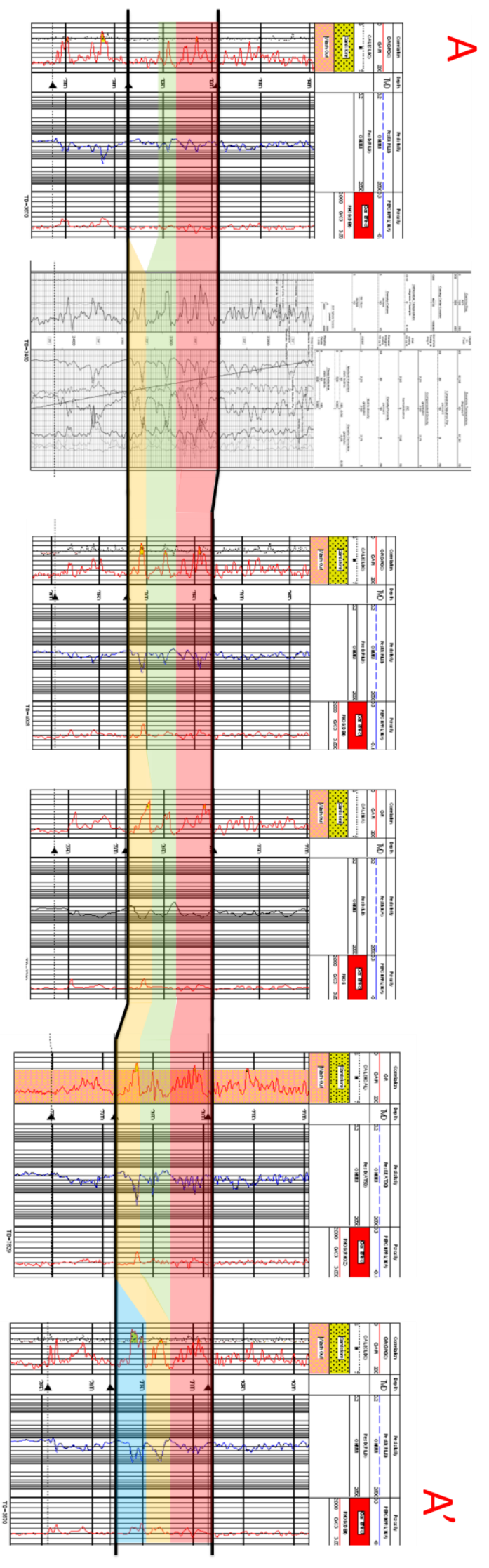

Figure 42. Stratigraphic cross section of the Fifth sandstone. The datum is the top of the Fifth sandstone unit. Blue shading highlights sequence one, orange shading highlights sequence two, green shading highlights sequence three, red shading highlights sequence four. 


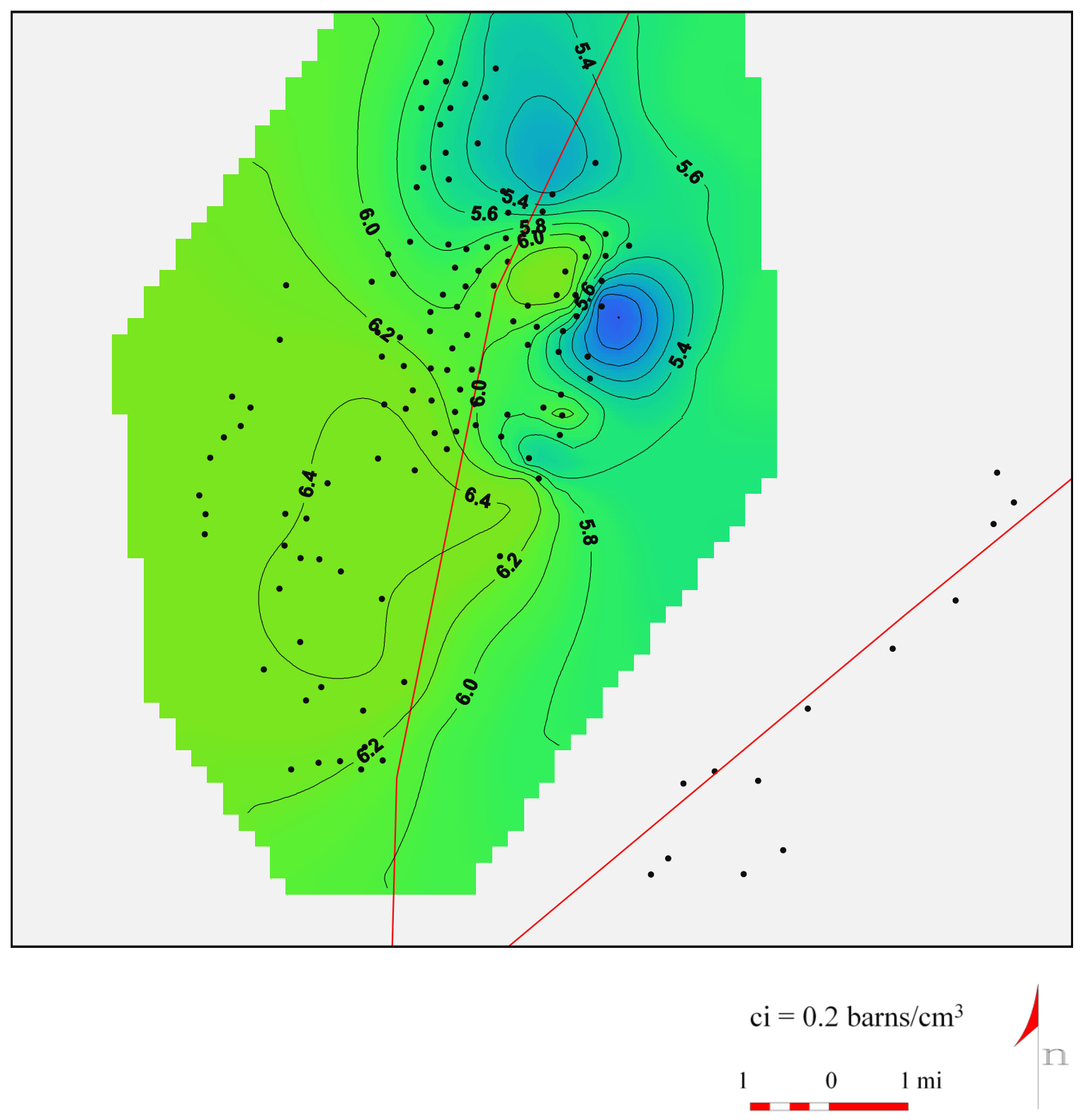

Figure 43. Fifth sandstone sequence one Umaa map. Cool colors indicate low Umaa values suggesting quartz-rich rocks and warmer colors indicate higher Umaa values suggesting increased calcite or clay content. 


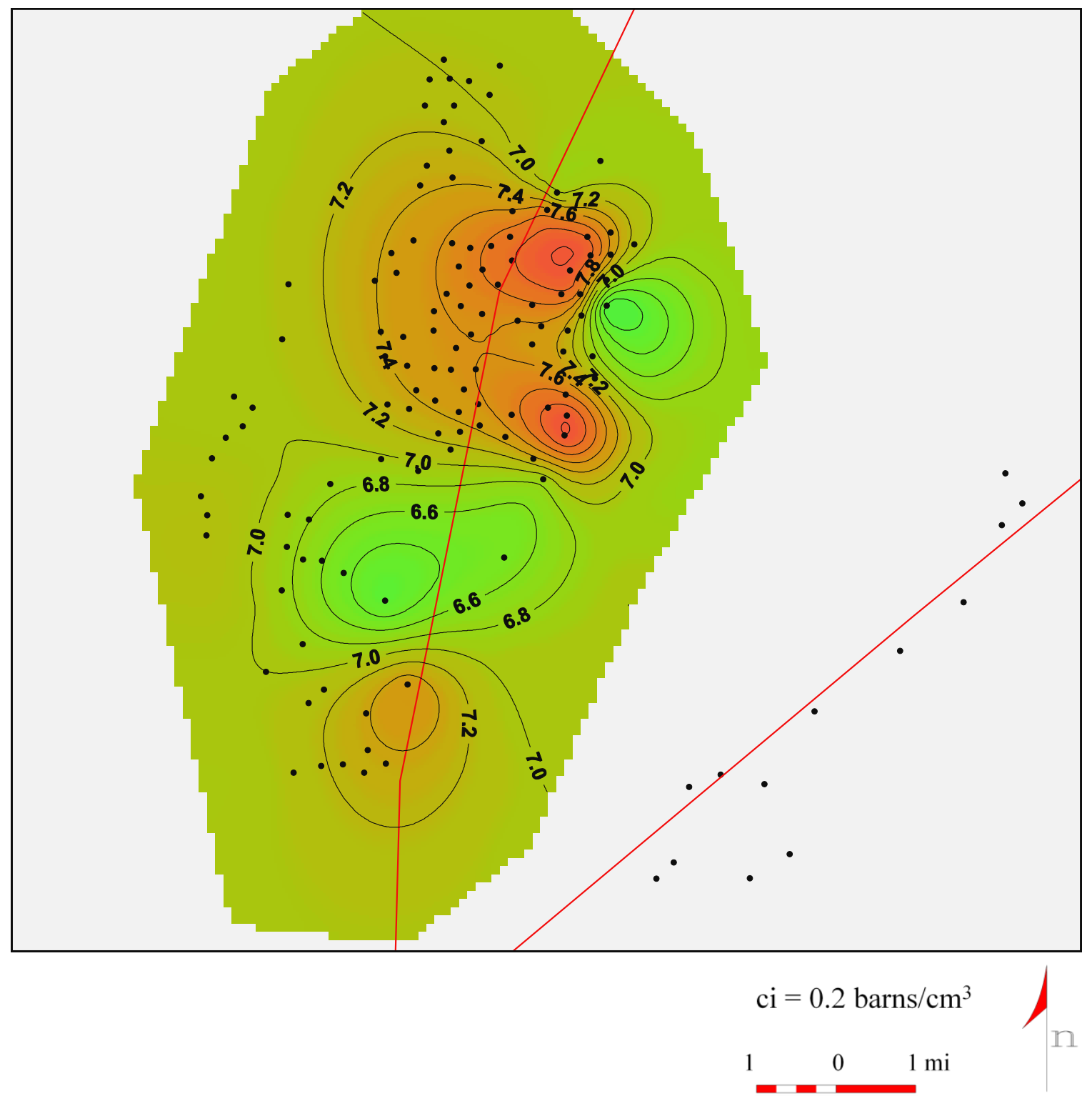

Figure 44. Fifth sandstone sequence two Umaa map. Cool colors indicate low Umaa values suggesting quartz-rich rocks and warmer colors indicate higher Umaa values suggesting increased calcite content. 


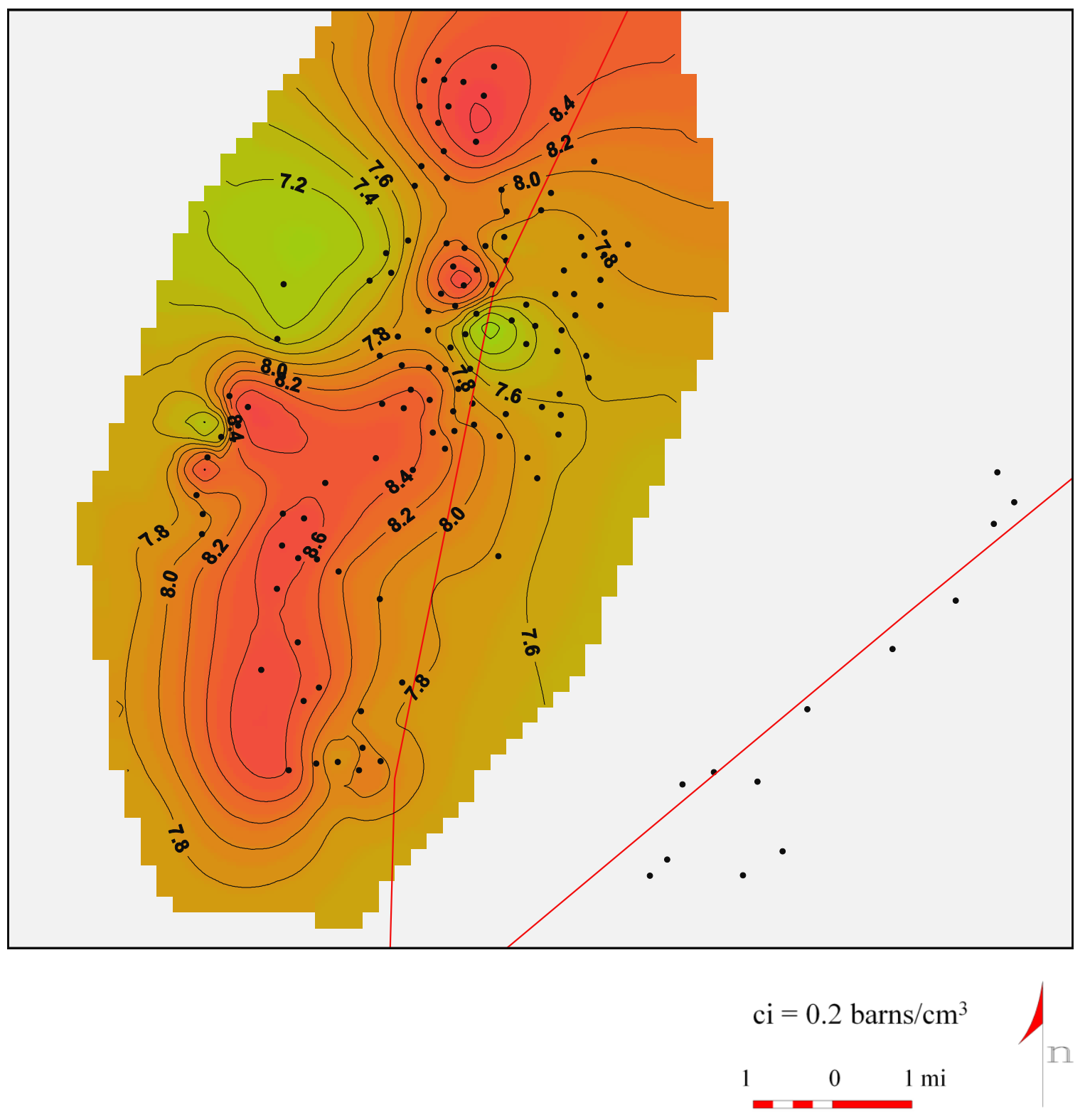

Figure 45. Fifth sandstone sequence three Umaa map. Cool colors indicate low Umaa values suggesting quartz-rich rocks and warmer colors indicate higher Umaa values suggesting increased calcite content. 


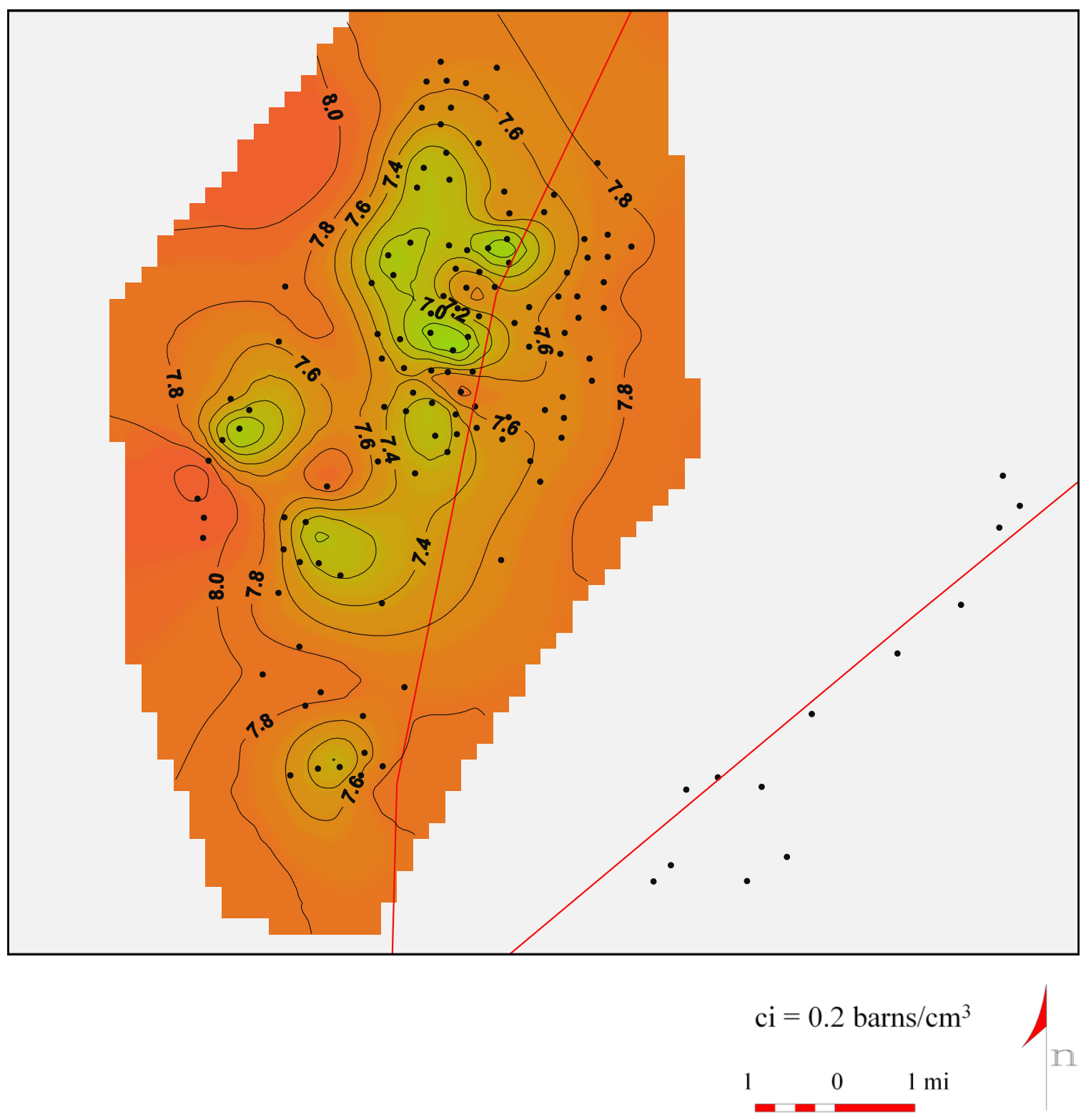

Figure 46. Fifth sandstone sequence four Umaa map. Cool colors indicate low Umaa values suggesting quartz-rich rocks and warmer colors indicate higher Umaa values suggesting increased calcite content. 
Fifth Sandstone Unit Interpretation

LaSota (1988) completed thin section analysis on the Fifth sandstone unit from a well within two miles of the study area. The author identified three sandstone sequences and interpreted them as separate phases of fluvial sedimentation. In northern West Virginia (fifty miles to the south), the Fifth sandstone unit was interpreted as both fluvial and shoreline sandstones (Peace, 1985).

Within this study area, the Fifth sandstone unit was interpreted to have different depositional environments for the four sequences. Sequence one was interpreted as a fluvial sandstone sequence. Sequences two and three were interpreted as prograding shoreface sandstones. Sequence four was interpreted as a retrograding shoreface sandstone.

The fluvial interpretation for sequence one is supported by the following: 1) the net sand map shows limited areal extent and a distinct channel morphology; 2) the logs and cross sections show a fining up sandstone sequence, a sharp basal contact, and down-cutting indicative of fluvial-channel fills; and 3) the Umaa map shows an extremely high quartz content that was likely sourced from high energy fluvial systems.

The prograding shoreface interpretation for sequence two is supported by the following: 1) the net sand map shows a more laterally extensive sandstone sequence that was shifted west relative to sequence one; 2) the logs and cross sections show sandstone sequences that are coarsening up and thinning to the west; and 3) the Umaa map shows high calcite content which is likely derived from marine sources.

The prograding shoreface interpretation for sequence three is supported by the following: 1) the net sand map shows a laterally extensive sandstone sequence that was 
shifted further west relative to sequence two; 2) the logs and cross sections show sandstone sequences that are coarsening up with a sharp top contact; and 3) the Umaa map also shows high calcite content which is derived from marine sources.

The retrograding shoreface interpretation for sequence four is supported by the following: 1) the net sand map shows a laterally extensive sandstone sequence that blankets the study area; 2) the logs and cross sections show sandstone sequences that are coarsening up or symmetrical and maintain thickness across the study area; and 3) the Umaa map also shows high calcite content which is derived from marine sources.

Sequence one of the Fifth sandstone unit was likely deposited within a distributary channel of a delta dominated coastal plain. During this period, quartz-rich siliciclastics were transported basinward by fluvial systems. As sedimentation increased, relative sea level dropped creating more accommodation space. Then a transgressive pulse generated a ravinement surface. This surface, a thin muddy offshore facies, seperates sequence one from sequences two and three. As sea level fell again sequences two and three were deposited on top as stacked regressive shoreface sequences. This stacked pattern indicates relative sea-level changed during the overall progradation due to low depositional gradients (Hamberg and Nielsen, 2000). Sequence four was likely deposited as part of a transgressive system. During this period, relative sea level increased and the shoreface migrated landward. The serrated and modified log appearance of this sandstone sequence suggests the shoreface was reworked by wave and tidal processes. 


\section{RESERVOIR CHARACTERISTICS}

The stratigraphic framework and associated net sandstone and Umaa maps provide a fuller understanding of sandstone geometry and depositional environments but do not necessarily identify the best reservoirs. In order to help identify new drilling locations, certain reservoir parameters were mapped. Degree of crossover (caused by the presence of natural gas) was averaged over sandstone zones with a gamma ray value of eighty API or less. The averaged crossover values were then mapped across the study area. This parameter is useful since it identifies potential gas bearing zones which may be independent of sandstone geometry. The same process was implemented with water saturation as a parameter. Low water saturation is important for all reservoirs because the absence of water means probable amounts of hydrocarbons. By identifying zones of low water saturation and large crossover, the prospect area can be optimized. 


\section{Balltown B Reservoir Characteristics}

The Balltown B degree of crossover map (Figure 47) shows the same trend as the net sandstone and Umaa maps. The maximum degree of crossover is 0.22 and is observed where the thickest and most quartz-rich Balltown B is present. The Balltown B water saturation map shows a similar trend (Figure 48). The minimum potential water saturation is approximately twenty percent and is located in the same region. This occurrence is directly linked to porosity and possibly the depositional environment. According to Smosna and Bruner (1997), primary porosity in sandstones, similar to the Balltown B, is largely controlled by the depositional environment. Since this sandstone was deposited in a high energy and clean environment, porosity is likely primary in origin. However the large degree of crossover may also suggest increased secondary porosity. Dissolution of minor amounts of lithics could also be the probable source of increased porosity Although low porosities are typical in these Upper Devonian sandstones, the Balltown B sandstone can have porosities as high as sixteen percent (Laughrey et al., 2004). 


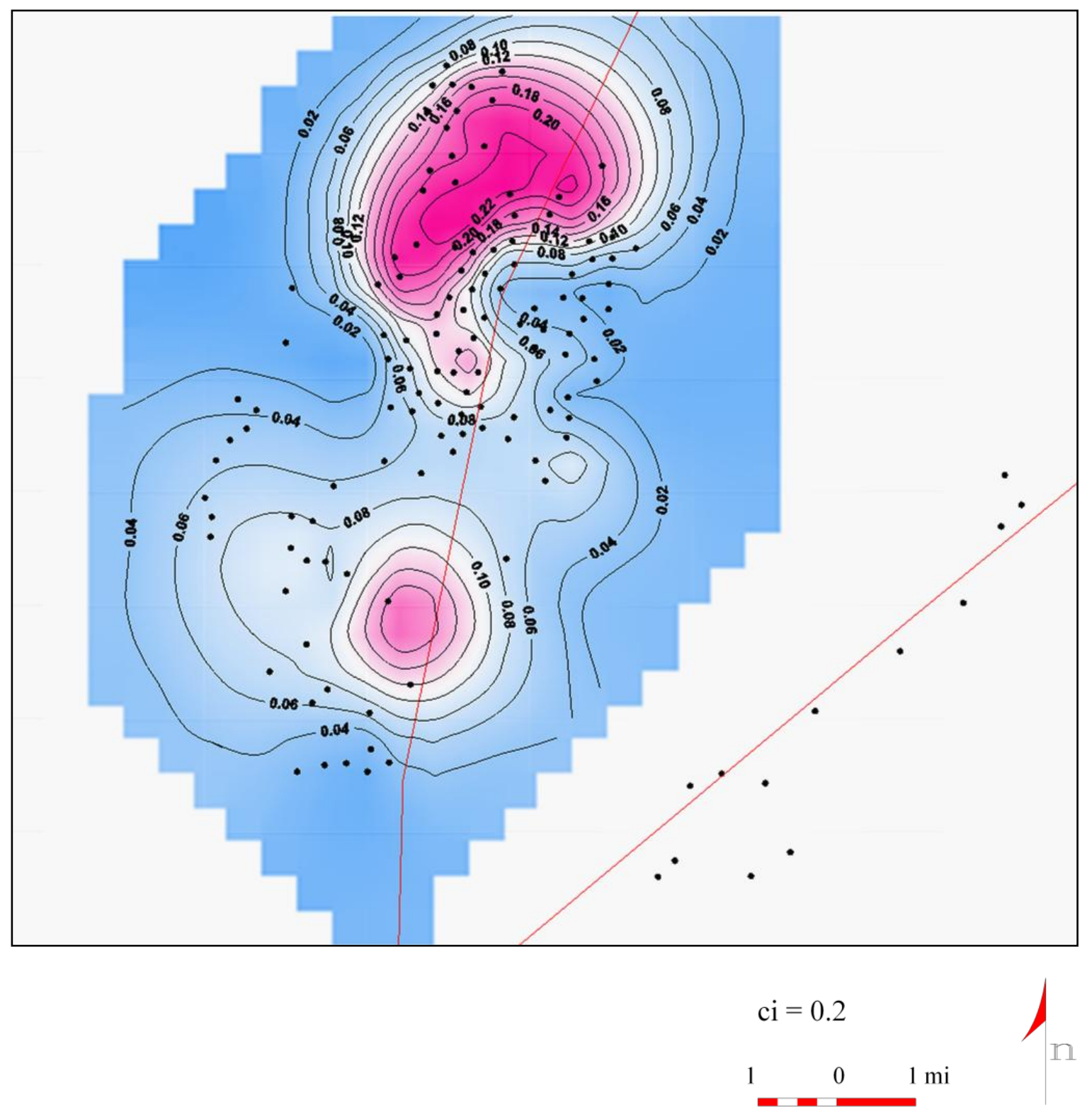

Figure 47. Balltown B unit degree of crossover map. Pink indicates cross over effect caused by the presence of hydrocarbons; blue indicates a lack of hydrocarbons. 


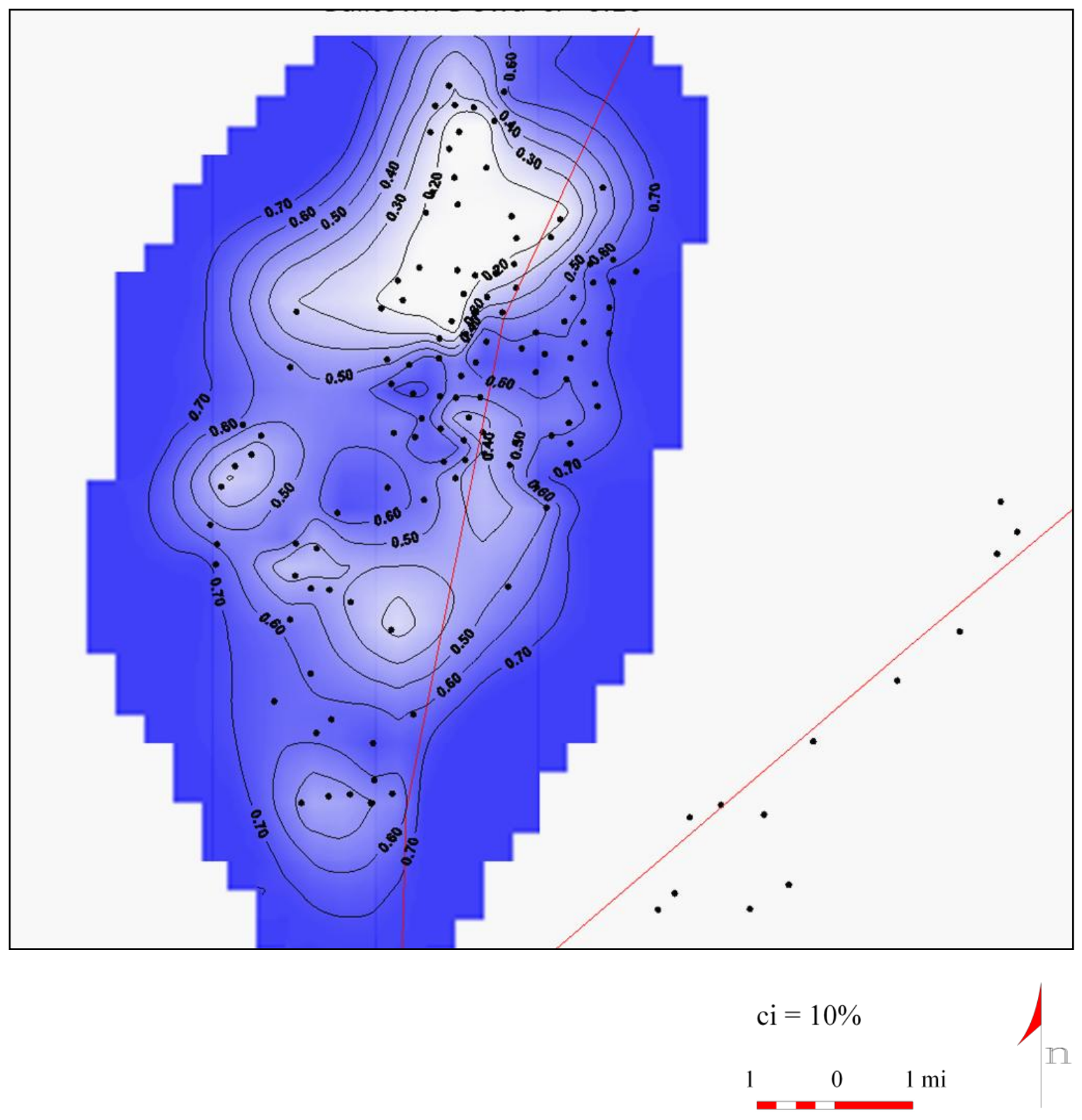

Figure 48. Balltown B unit water saturation map. Blue indicates a high percentage of water, white indicates a low percentage of water. 


\section{Speechley Reservoir Characteristics}

The Speechley degree of crossover map (Figure 49) correlates with the net sandstone and Umaa maps of the lower Speechley sequence. The maximum degree of cross over is 0.20 but is limited to one spot. This unit has lower gas effect when compared to the Balltown B sandstone. The water saturation map shows a similar trend (Figure 50). The minimum water saturation is approximately twenty percent and correlates with an eighteen foot sandstone lobe of the lower Speechley sequence. Larger crossover values and low water saturation values correlate well with the lower sequence which is likely linked to porosity. The Umaa map suggests that this sequence is very clean with limited amounts of calcite cement. Since this sandstone is relatively clean, porosity is likely primary in origin. The upper sequence conversely has significantly more lithics and calcite cement. This suggests that the porosity is cemented up or the pores are filled with lithics producing a less than optimum reservoir. 


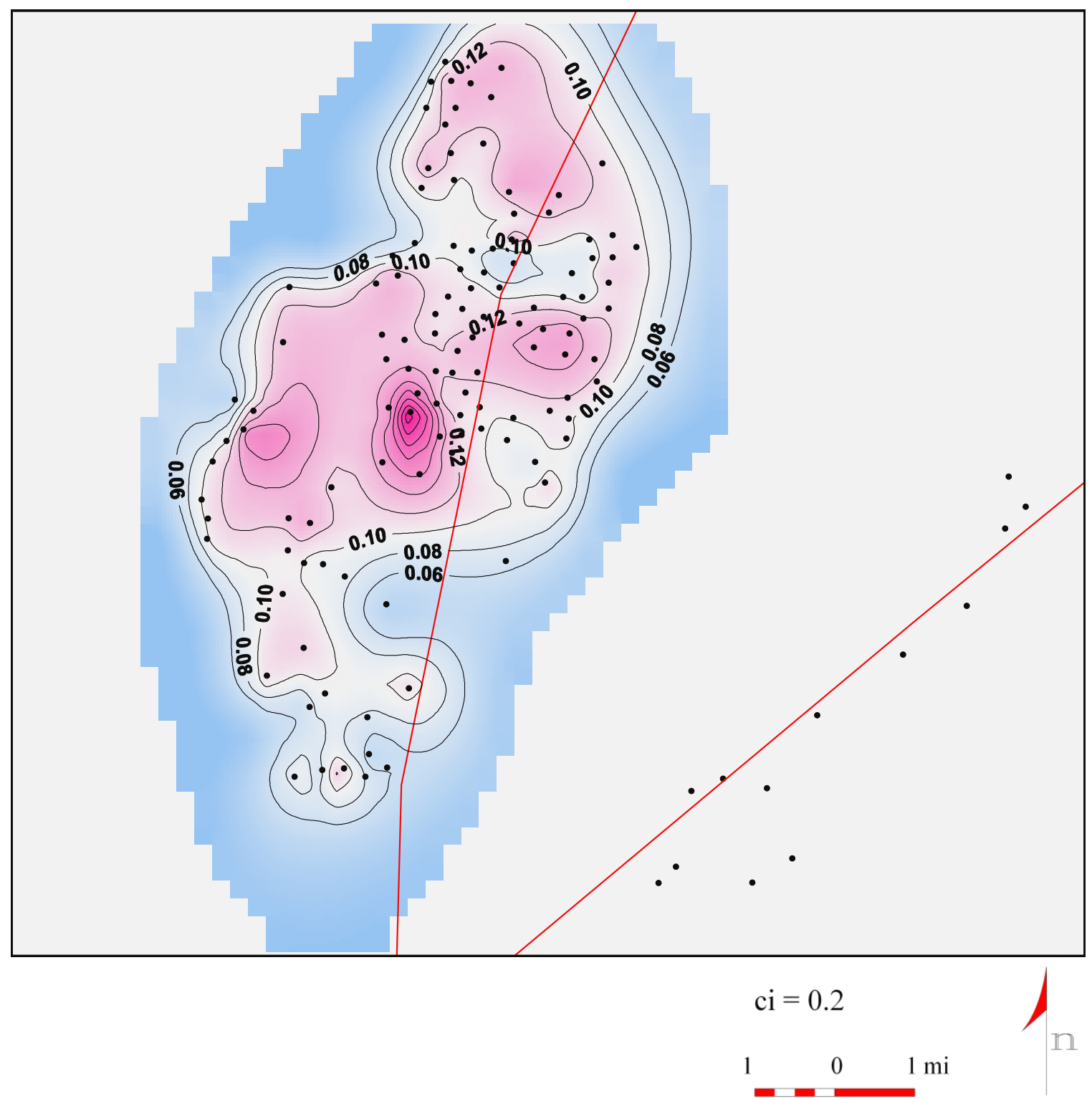

Figure 49. Speechley degree of crossover map. Pink indicates cross over effect caused by the presence of hydrocarbons; blue indicates a lack of hydrocarbons. 


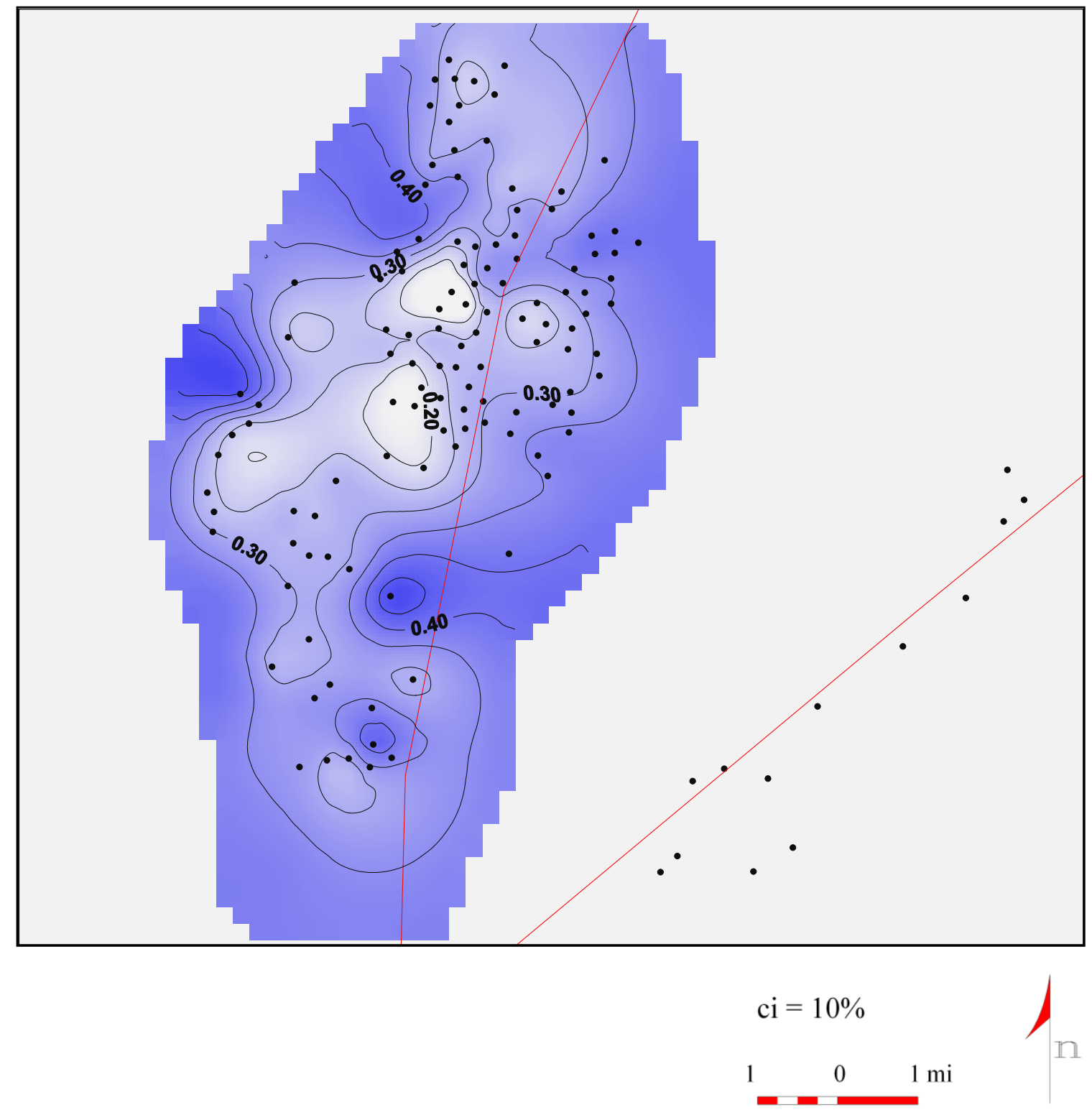

Figure 50. Speechley water saturation map. Blue indicates a high percentage of water, white indicates a low percentage of water. 


\section{Speechley Stray Reservoir Characteristics}

The Speechley Stray degree of crossover map (Figure 51) correlates with the net sandstone and Umaa maps of the Speechley Stray. The maximum degree of crossover is 0.20 and is aerially extensive. This unit has a significant amount of gas effect across the study area. The water saturation map shows the same trend (Figure 52). The minimum potential of water saturation is approximately twenty percent and correlates with the thick and laterally extensive section of the Speechley Stray. Since the Umaa map shows a small amount of clay or calcite cement, these optimistic reservoir parameters could be a result of high secondary porosity. Smosna and Bruner (1997) determined that the best porosity is found in mouth-bar or shelf sandstones with a moderate amount of lithics. The presence of lithics and calcite cement allows for dissolution and the creation of secondary porosity. This occurrence is further supported by the interpreted depositional environment of a muddy siliciclastic shoreline. 


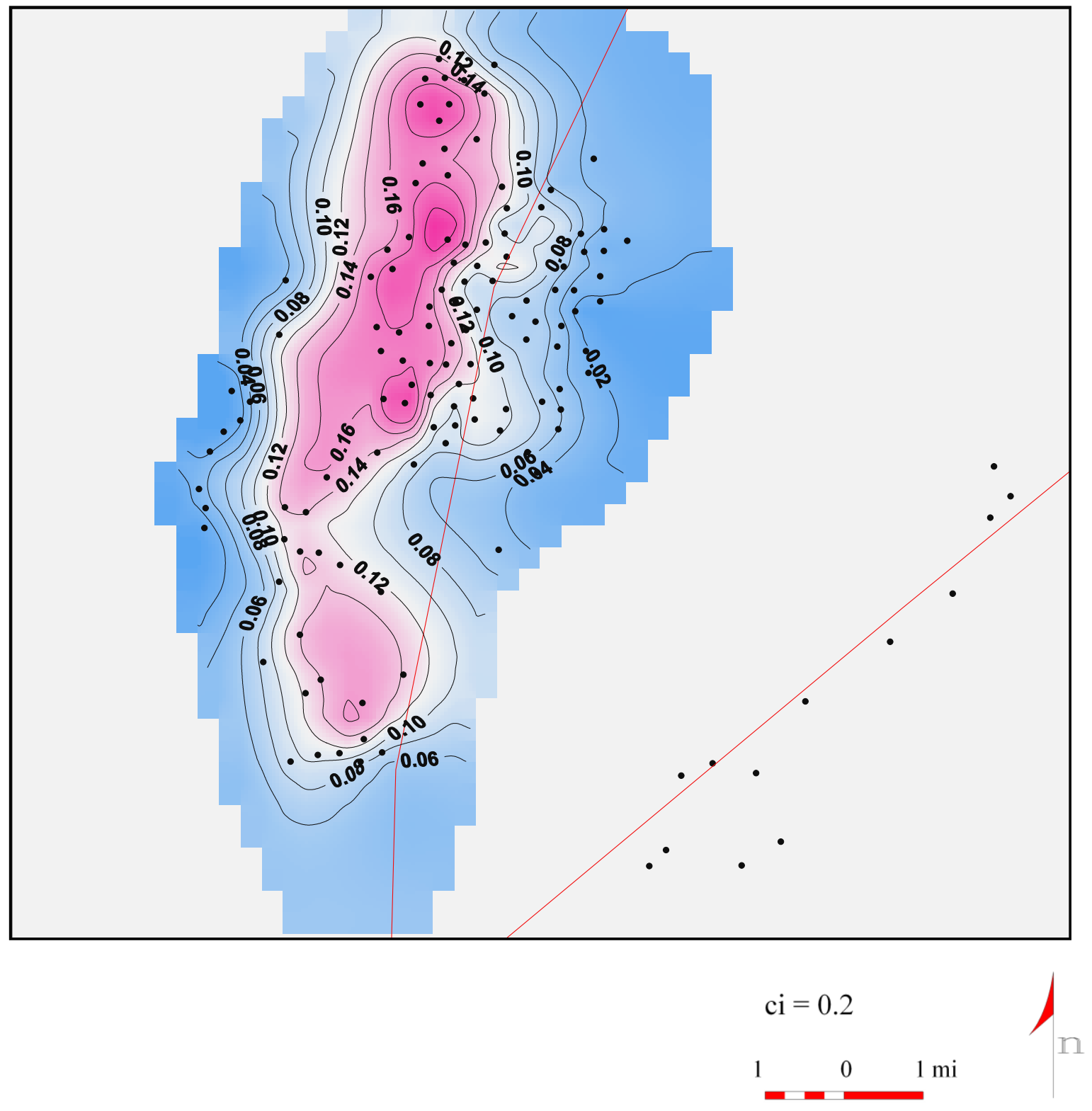

Figure 51. Speechley Stray degree of crossover map. Pink indicates cross over effect caused by the presence of hydrocarbons; blue indicates a lack of hydrocarbons. 


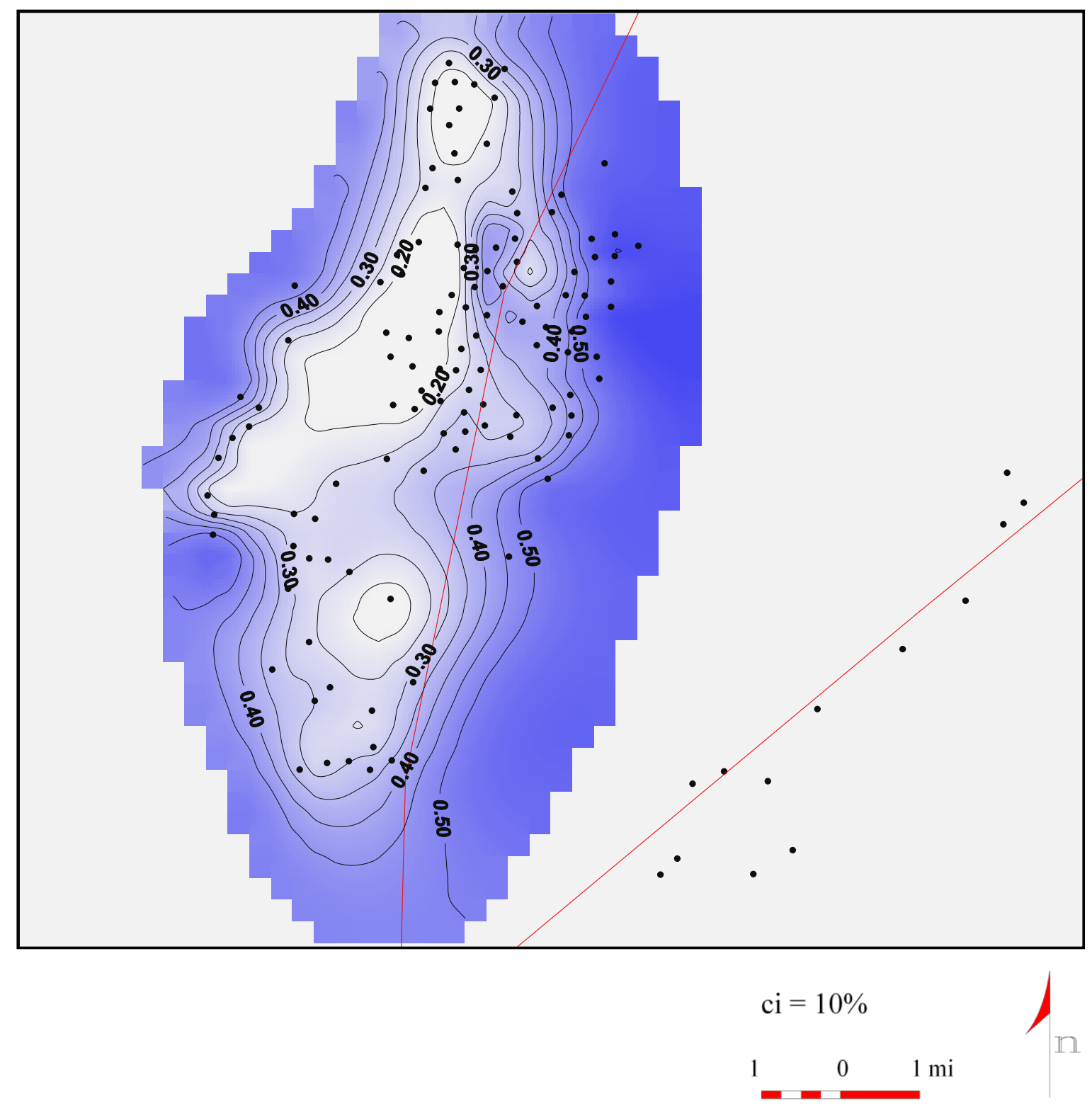

Figure 52. Speechley Stray water saturation map. Blue indicates a high percentage of water, white indicates a low percentage of water. 


\section{Bayard Reservoir Characteristics}

The Bayard degree of crossover map (Figure 53) shows a similar trend as the Bayard lower sequence net sandstone map. The maximum degree of crossover is 0.24 and is isolated to the north of the study area. This sequence has the largest degree of crossover in the study area but is limited in extent. The water saturation map shows a similar trend (Figure 54). The minimum potential of water saturation is approximately 25 percent and correlates with the thickest section of the Bayard lower sequence. Although there are trends observed, the water saturation map, degree of crossover map, Umaa map, and net sandstone map do not correlate as well as previous sandstone units. This may be due to a lack of porosity. The Bayard lower sequence is interpreted to be extremely clean sandstone. LaSota (1988) analyzed this sequence and determined it was 95 percent quartz with a total porosity of 2.8 percent. Therefore the best porosity may be a result of secondary processes which do not necessarily correlate with the thickest sandstone. 


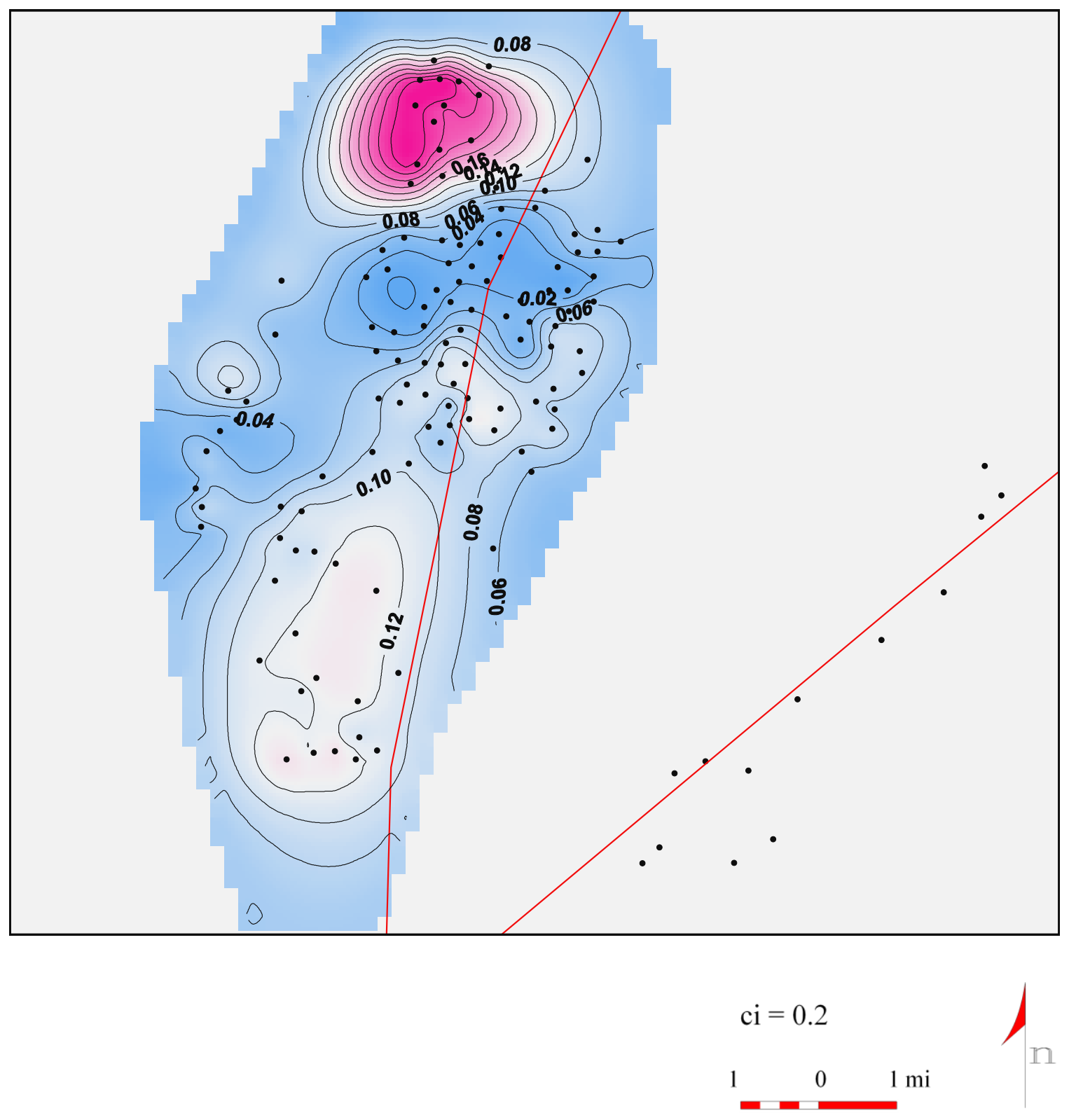

Figure 53. Bayard degree of crossover map. Pink indicates cross over effect caused by the presence of hydrocarbons; blue indicates a lack of hydrocarbons. 


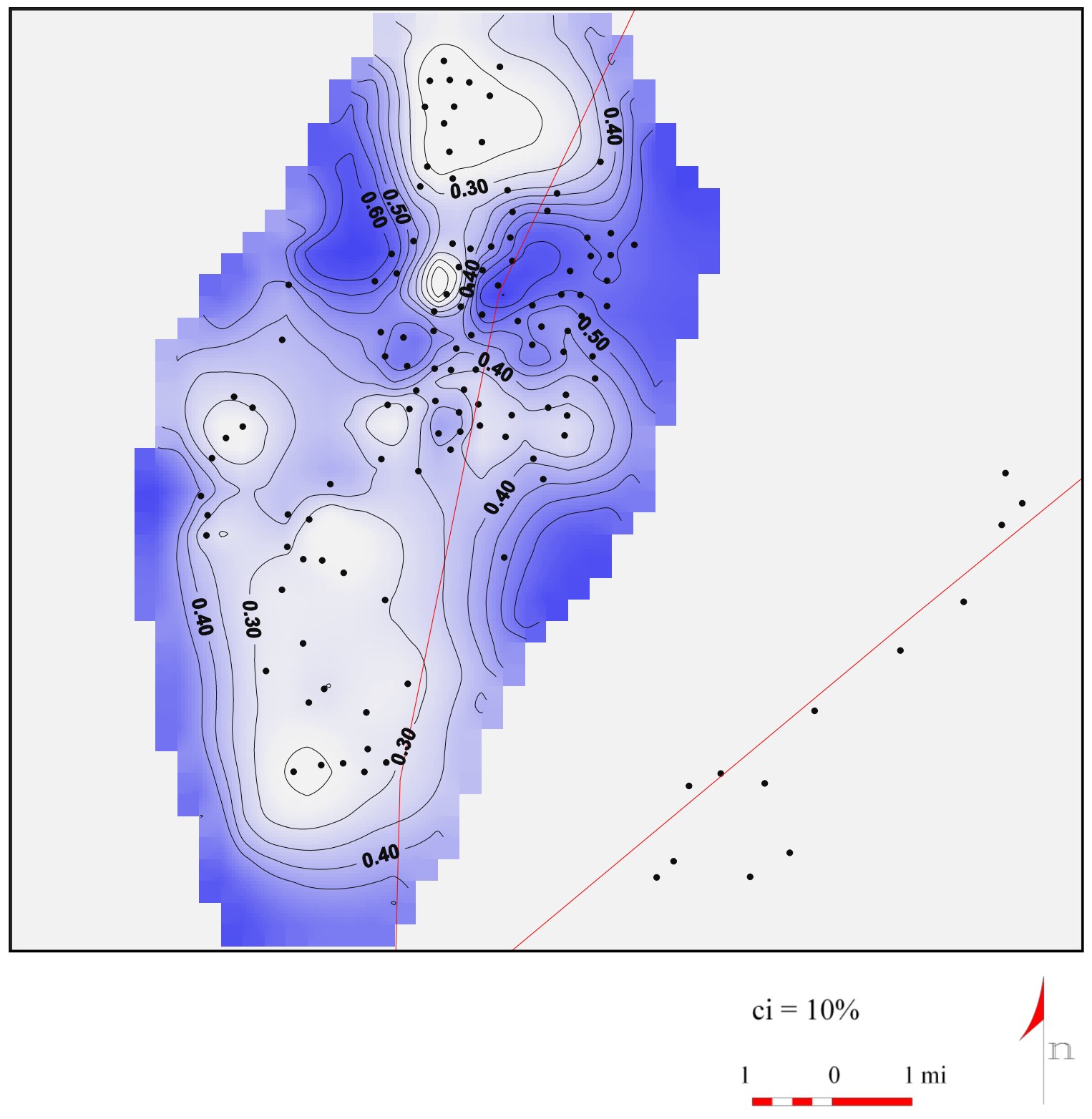

Figure 54. Bayard water saturation map. Blue indicates a high percentage of water, white indicates a low percentage of water. 


\section{Fifth Sandstone Reservoir Characteristics}

The Fifth sandstone degree of crossover map (Figure 55) shows a similar trend as the Fifth sandstone sequences one and four net sandstone maps. The maximum degree of crossover is 0.12 . The best zone of crossover is lobate in appearance and correlates with sequence one. Overall, this unit has the smallest degree of cross over in the study area. The water saturation shows a slightly different trend (Figure 56). The minimum potential of water saturation is approximately twenty percent and correlates with the thickest sandstone section of sequences one and four. The Umaa map also shows a strong correlation between quartz-rich sandstone sections of sequence one with low water saturation. These reservoir parameters, however, are the least impressive when compared to previous sandstone units. According to the Umaa map, sequence four has a large amount of calcite material. These constituents may be too abundant to allow good development of secondary porosity. 


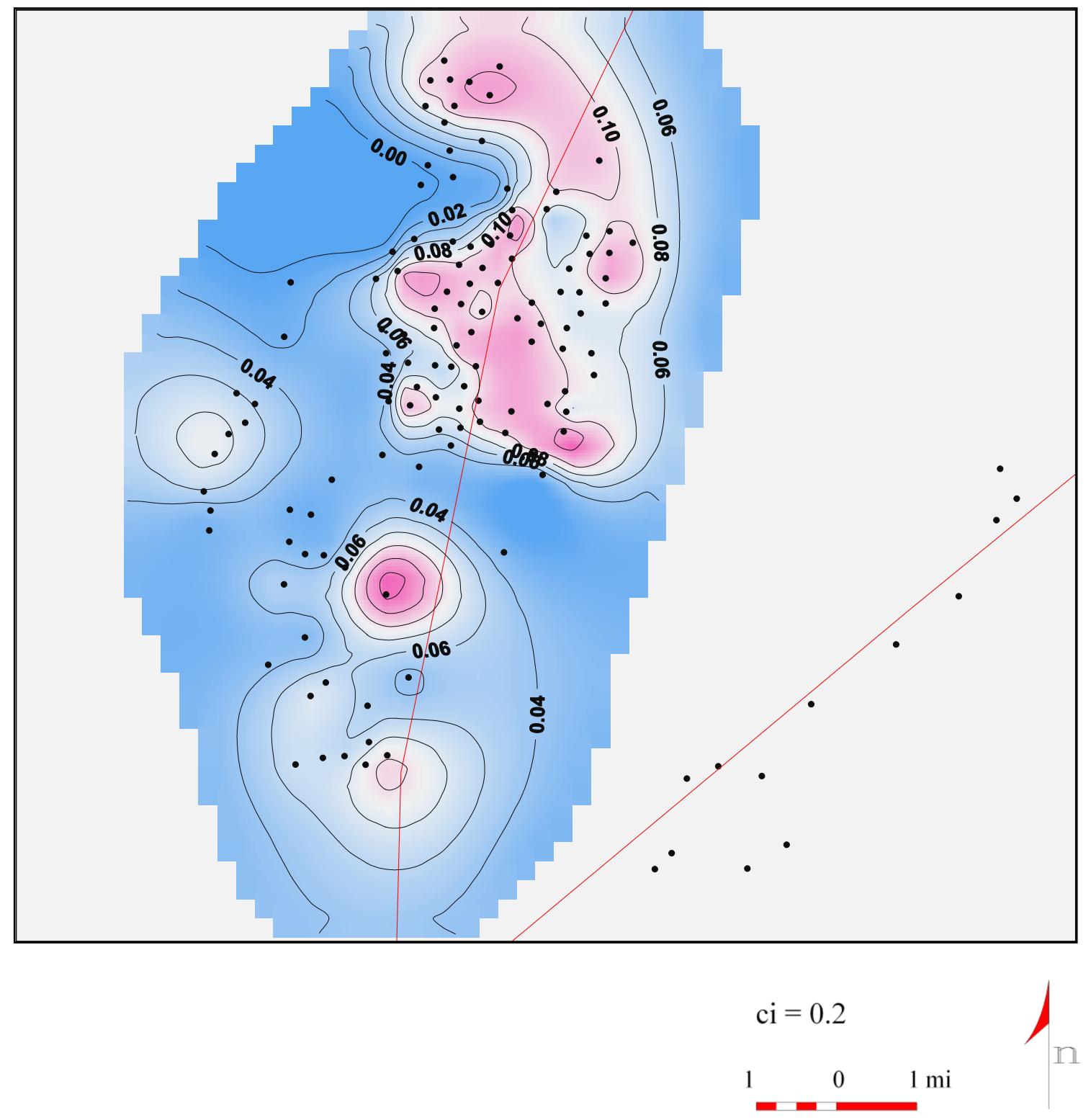

Figure 55. Fifth sandstone degree of crossover map. Pink indicates cross over effect caused by the presence of hydrocarbons; blue indicates a lack of hydrocarbons. 


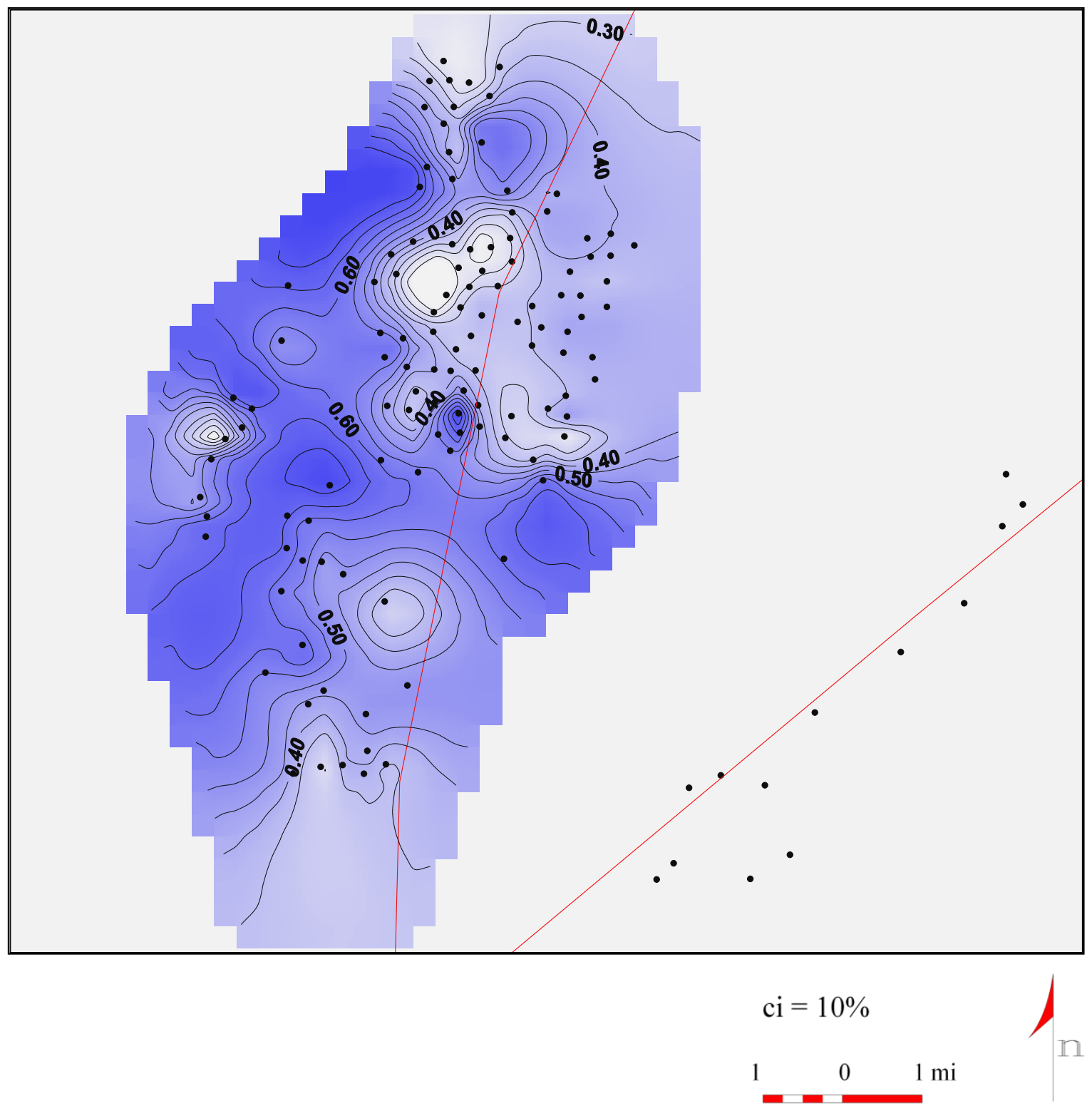

Figure 56. Fifth sandstone water saturation map. Blue indicates a high percentage of water, white indicates a low percentage of water. 


\section{PRODUCTION}

In the Appalachian basin, the Bradford and Venango sandstone units are the most productive natural gas reservoirs. Decades of production have provided an abundance of data. To ensure consistent comparison among producing wells, only aftertreatment open-flow values were used for mapping purposes. These values were chosen because they are not influenced by pipeline pressures that can suppress gas flow.

Even with the abundance of production data, linking specific sandstone units to production remains difficult. This difficulty stems from the commingled gas produced from multiple reservoirs. For this reason, production data could not be identified and mapped for individual sandstone units. Instead, commingled production data were mapped across the study area (Figures 57). Production values have units of a thousand cubic feet of gas per day (Mcfg/d). Production maps were used for comparison against net sandstone, structure, Umaa and other maps.

The production isomap with surface structure indicates that production is not dependent on structural position. The majority of wells are located along the Grapeville anticline; however, this trend is unrelated to reservoir quality. While wells are constrained by established lease locations, the highest levels of production are offstructure on the limbs of the Grapeville anticline, and not at the structural apex (Figure $57)$.

A production bubble map was generated to show production rates of individual wells. This map was compared to all of the sandstone units and sequences (Figure 58). With some exceptions, the best production coincides with sandstone thickness, indicating that gas reservoirs are primarily stratigraphic traps. The Bradford Group 
sandstone units including the Balltown B, Speechley, and Speechley Stray display these trends. The Venango Group sandstone units did not display any significant trends with the exception of the Fifth sandstone sequence one.

The Balltown B sandstone unit shows a correlation between sandstone thickness and natural gas production. Three wells identified by yellow circles produced daily initial flow rates of a million cubic feet or greater. In addition, three wells identified by green circles produced initial flow rates of $800 \mathrm{Mcfg} / \mathrm{d}$ or greater. Wells with high initial flow rate coincide with the thick channelized sandstone of the Balltown B located to the north (Figure 59). The higher production rates of the channelized Balltown B sandstone are atributed to thickness as opposed to increased permeability or porosity. The Balltown B is interpreted as fluvial sandstone with quartz-rich mineralogy. This sandstone unit likely has average porosity with the majority of it being primary in origin. The Umaa and water saturation maps for the Balltown B indicate this sandstone is not water-rich, and potentially has gas saturation approaching eighty percent.

The lower sequence of the Speechley sandstone unit appears to be the most prolific natural gas producer (Figure 60). Four wells identified by pink and red circles produced initial flow rates in excess of 1.2 million cubic feet per day. These wells coincide with the thickest section of the lower Speechley sequence. Other reservoir parameters could have influenced production, however, the high production rates of this sandstone sequence are likely due to the vertical and aerial extent. Previous studies suggest the Speechley sandstone unit has average permeability $(0.25 \mathrm{md})$ and porosity (6 percent) (Boswell et al., 1988). As observed in the water saturation map of the lower Speechley sequence, this sandstone is not water-rich. Gas saturation could be as high as eighty percent which falls within the typical range of Bradford sandstone reservoirs 
(Boswell et al., 1988). The massive size of this sandstone, in addition to high gas saturation, makes the lower Speechley sequence an impressive reservoir.

The Speechley Stray sandstone unit shows a correlation between sandstone thickness and natural gas production (Figure 61). Three wells identified by yellow circles produced initial daily flow rates of a million cubic feet or greater. The high initial rate wells coincide with thicker lobes of the Speechley Stray. The Speechley Stray is not as thick as the lower Speechley sequence; however, it is aerially extensive. Higher production rates of the Speechley Stray sandstone could be in response to increased porosity. Sandstone deposited along a shoreline such as the Speechley Stray tends to have more cement. The dissolution of this cement could lead to higher secondary porosity. The Speechley Stray degree of crossover map may also suggest increased porosity (Figure 51). Since Speechley Stray sandstone unit is thinner than the lower Speechley sequence and has a more extensive degree of crossover, porosity could be significantly higher.

Sequence one of the Fifth sandstone also shows a correlation between sandstone thickness and natural gas production (Figure 62). Numerous wells identified by dark blue circles produced initial daily flow rates of $200 \mathrm{Mcfg} / \mathrm{d}$ or greater. These wells coincide with the channelized and sinuous sandstone of sequence one. The Fifth sandstone sequence one is not thick and aerially extensive; however, where the sandstone is thickest, low water saturations are present as seen in the water saturation map (Figure 56). This fluvial sandstone likely has average porosity which is supported by the Fifth sandstone degree of crossover map (Figure 55). 


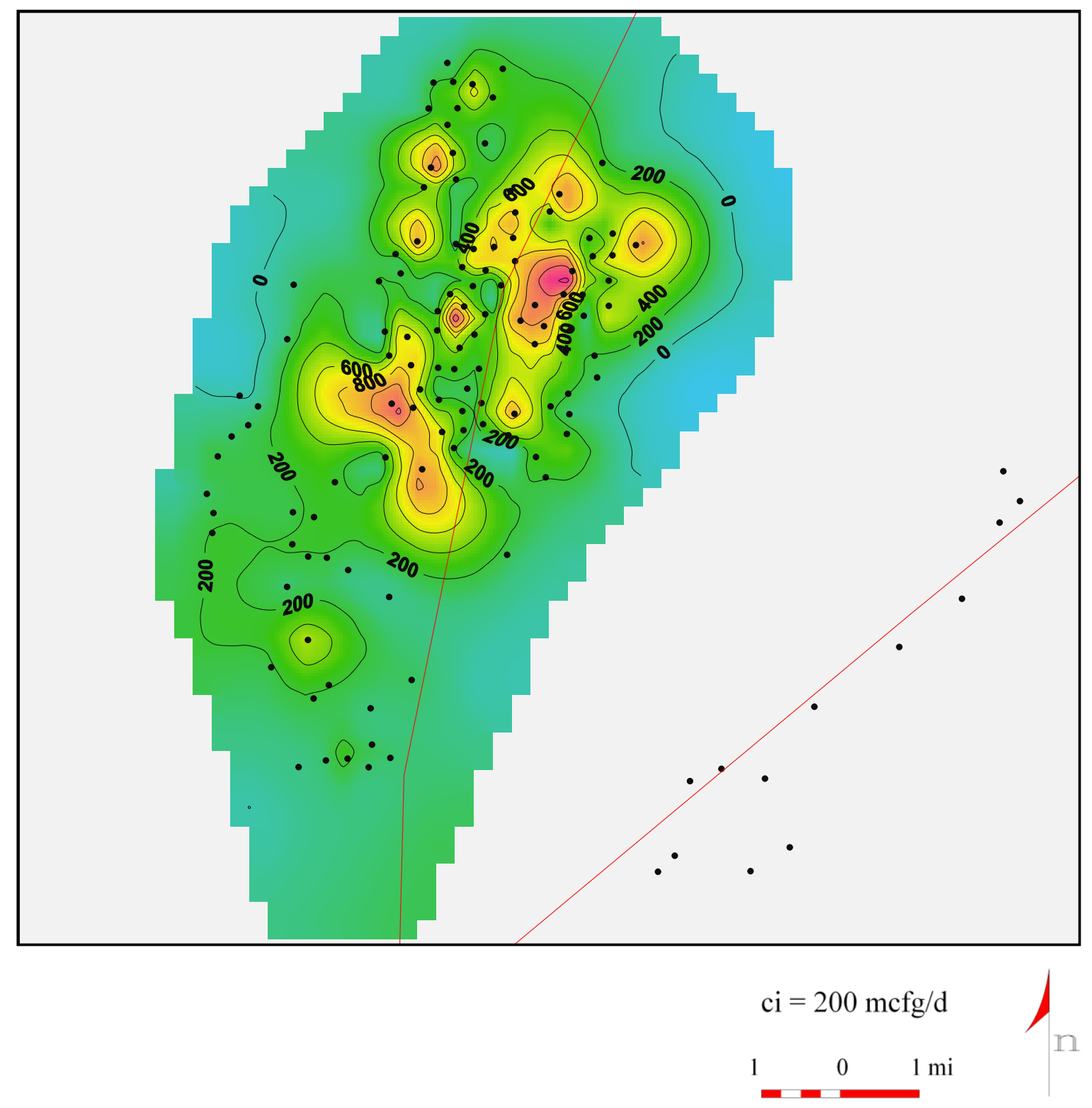

Figure 57. Isomap of commingled gas open flow production rates. Primary contour intervals are spaced at 200 thousand cubic feet of gas per day. Blue and green indicate low production rates; pink and red indicate high production rates. 


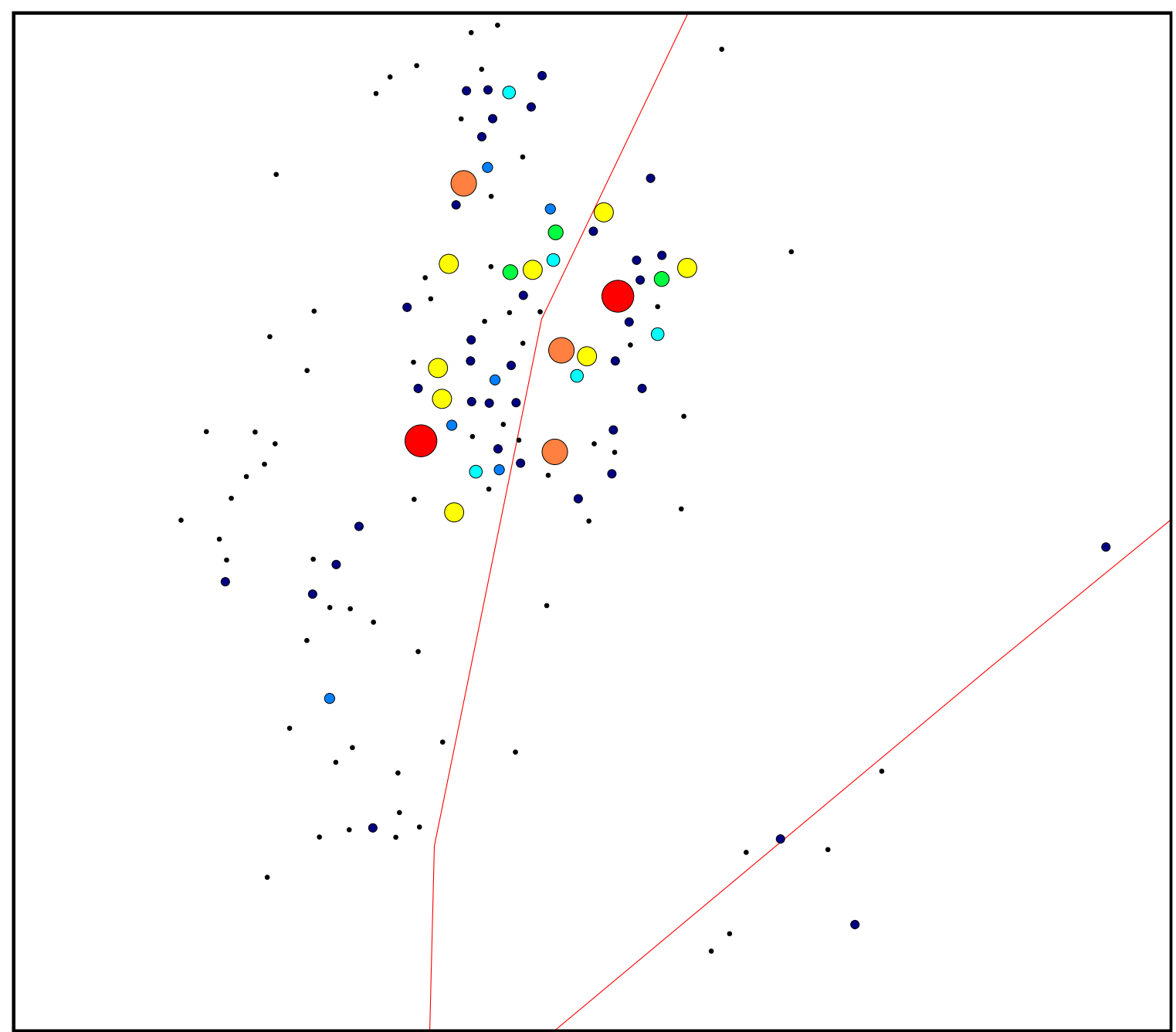

\begin{tabular}{|c|c|c|c|}
\hline \multicolumn{4}{|c}{ Production Map Key } \\
$\begin{array}{c}\text { Mell } \\
\text { Color }\end{array}$ & $\begin{array}{c}\text { Well } \\
\text { Marker } \\
\text { Size }\end{array}$ & $\begin{array}{c}\text { Well Marker } \\
\text { Shape }\end{array}$ & $\begin{array}{c}\text { After Treatment } \\
\text { Open Flow } \\
\text { Production Rates } \\
\text { (mcfg/d) }\end{array}$ \\
\hline & 200 & Circle & $0-200$ \\
\hline & 400 & $\bigcirc$ Circle & $200-400$ \\
\hline & 480 & $\bigcirc$ Circle & $400-600$ \\
\hline 600 & $\bigcirc$ Circle & $600-800$ \\
\hline & 700 & $\bigcirc$ Circle & $800-1000$ \\
\hline & 900 & $\bigcirc$ Circle & $1000-1200$ \\
\hline 1200 & $\bigcirc$ Circle & $1200-1400$ \\
\hline & 1500 & $\bigcirc$ Circle & $1400-1600$ \\
\hline
\end{tabular}

Figure 58. Production bubble map of commingled gas open flow production rates. Small circles with cool colors indicate lower production rates. Large circles with hot colors indicate higher production rates. 

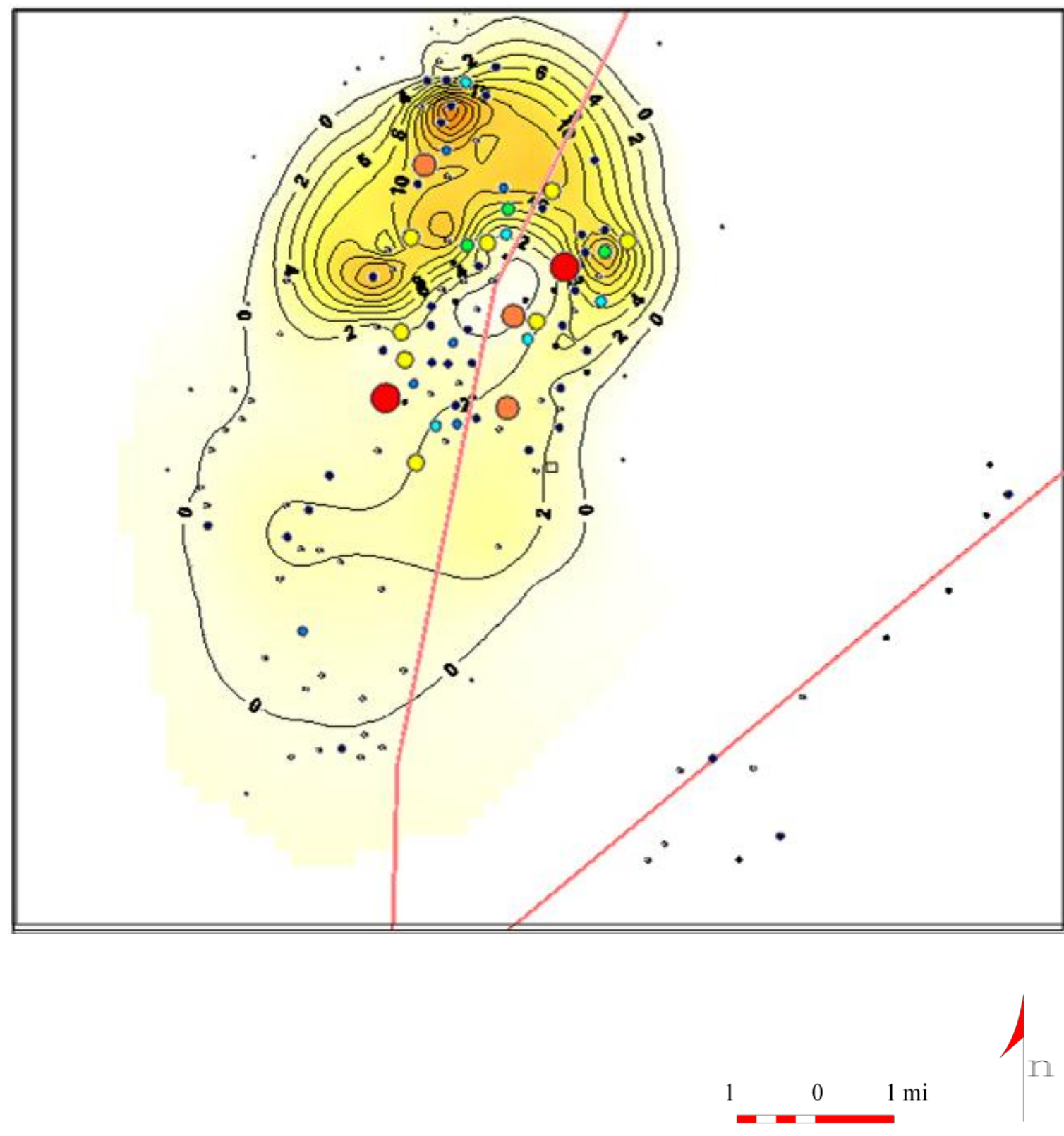

Figure 59. Production bubble map of commingled gas open flow production rates combined with the net sandstone map of the Balltown B. Small circles with cool colors indicate low production rates (see Figure 58 for production scale). Large circles with hot colors indicate high production rates. Orange shading indicates thick sandstone sections decreasing to the white areas indicating thinner sandstone sections. 

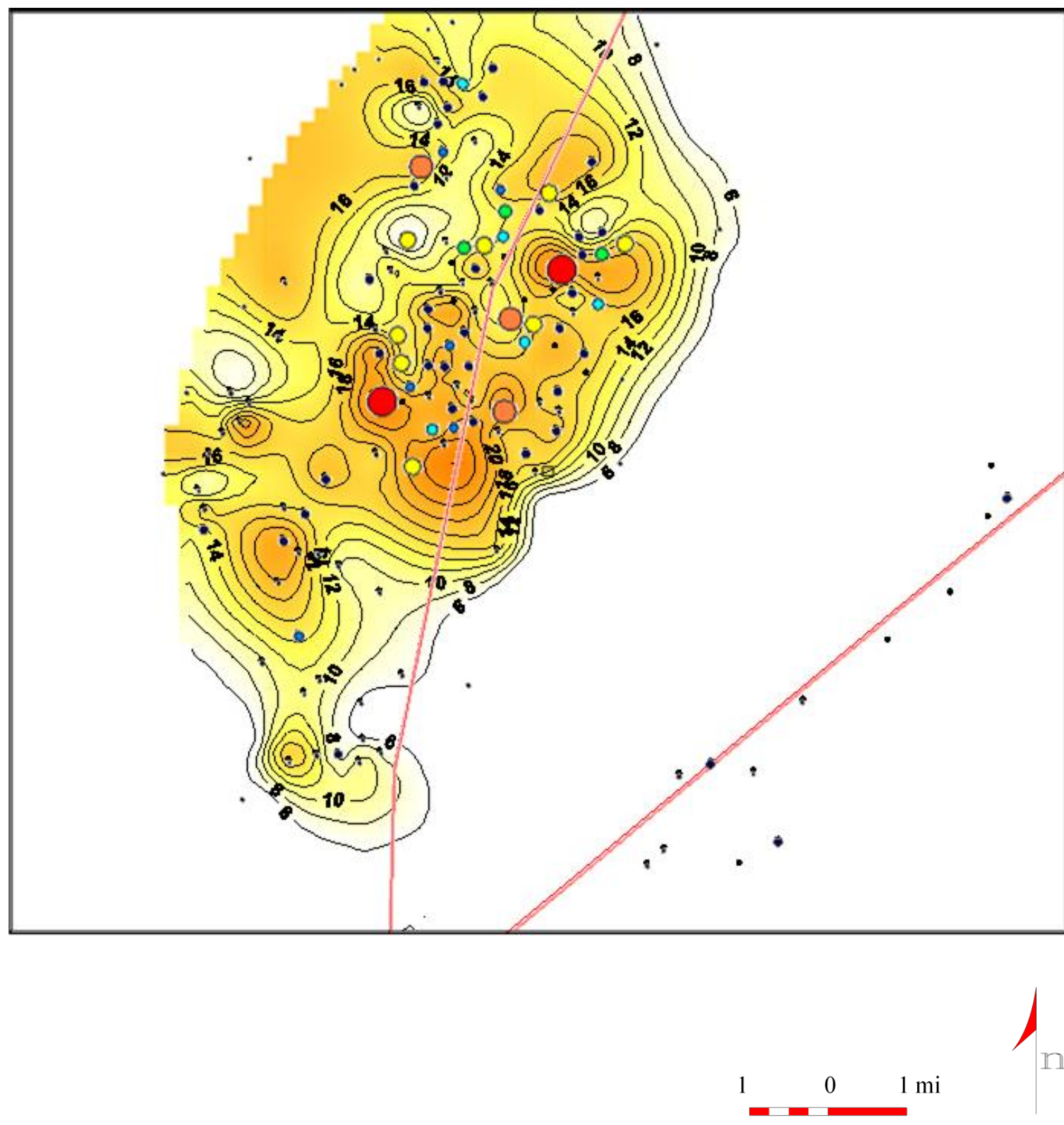

Figure 60. Production bubble map of commingled gas open flow production rates combined with the net sandstone map of the lower Speechley sequence. Small circles with cool colors indicate low production rates (see Figure 58 for production scale). Large circles with hot colors indicate high production rates. Orange shading indicates thick sandstone sections decreasing to the white areas indicating thinner sandstone sections. 

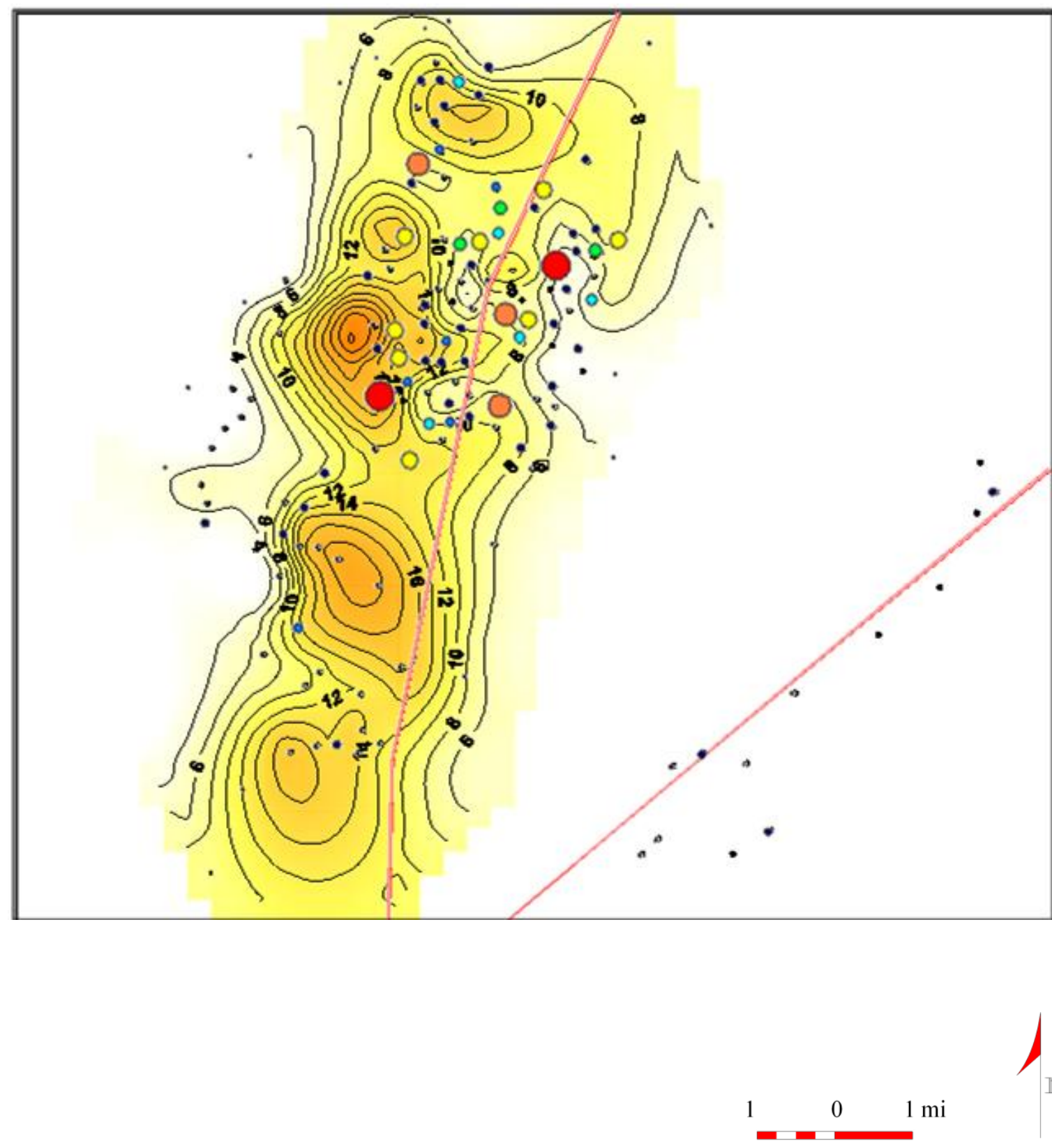

Figure 61. Production bubble map of commingled gas open flow production rates combined with the net sandstone map of the Speechley Stray. Small circles with cool colors indicate low production rates (see Figure 58 for production scale). Large circles with hot colors indicate high production rates. Orange shading indicates thick sandstone sections decreasing to the white areas indicating thinner sandstone sections. 

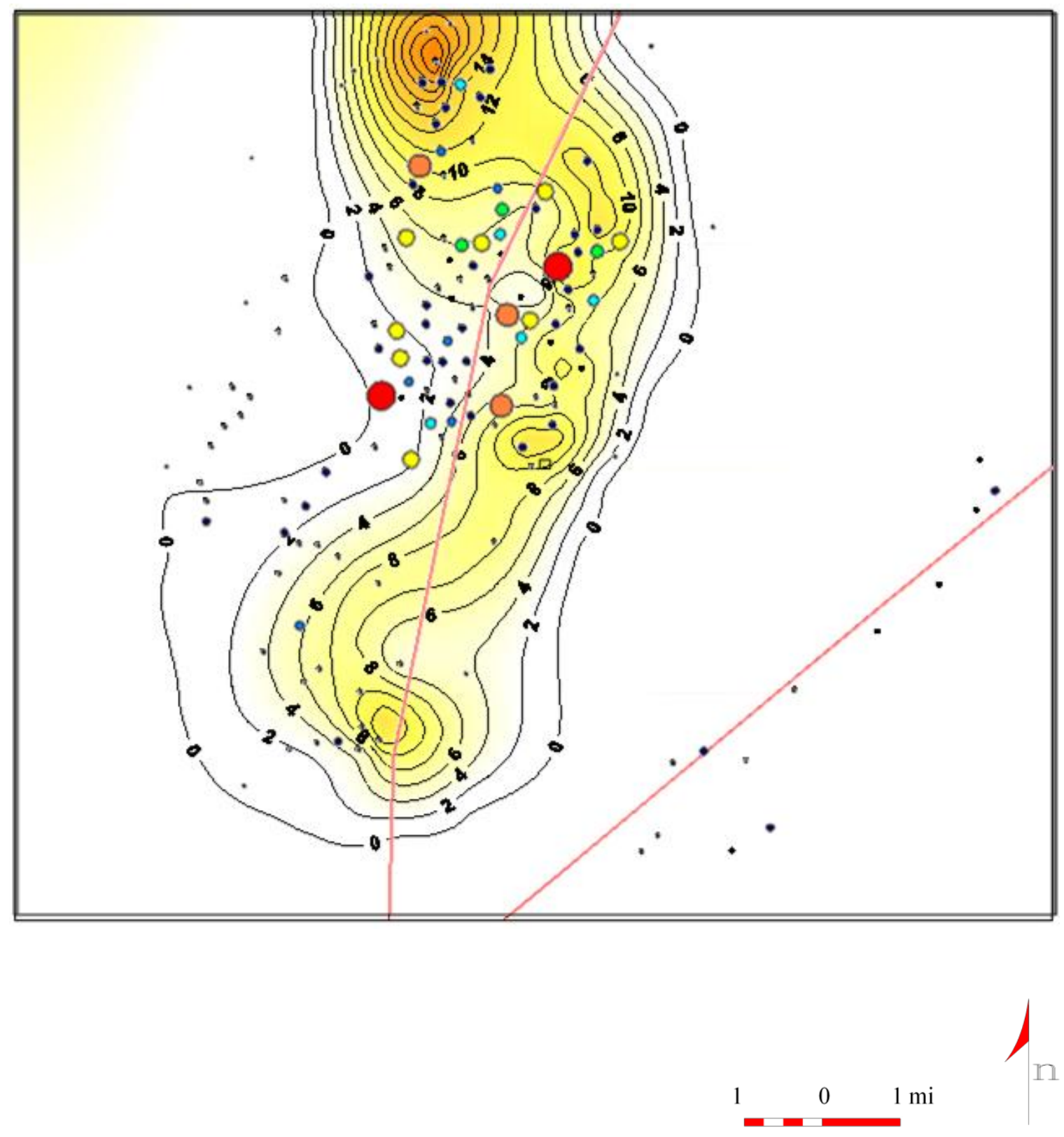

Figure 62. Production bubble map of commingled gas open flow production rates combined with the net sandstone map of the Fifth sandstone sequence one. Small circles with cool colors indicate low production rates (see Figure 58 for production scale). Large circles with hot colors indicate high production rates. Orange shading indicates thick sandstone sections decreasing to the white areas indicating thinner sandstone sections. 


\section{CONCLUSIONS}

No significant production trends were identified in the Venango Group sandstone units with the exception of the Fifth sandstone sequence one. As noted in a previous Venango sandstone study, the lack of production trends may be due to compartmentalization of the sandstone reservoirs (McBride, 2004). Numerous shale lenses and beds were observed in both the Fifth and Bayard Sandstone units. These partings could drastically affect permeability and porosity within each sandstone unit.

In the study area, the Balltown B, lower Speechley sequence, Speechley Stray, and Fifth sandstones sequence one appear to be the best natural gas producers. High production rates coincide with thick sandstone lobes and are not structurally influenced. Production trends also coincide with lithology. It appears that the quartz-rich fluvialdeltaic rocks are better targets than the carbonate dominated marine rocks. To date, many wells have been drilled along anticlines, with much less activity off structure. According to trends observed in this study area, these sandstone units should be targeted based on depositional trends and lithology, not structure.

The best drilling target is the lower Speechley sequence. Despite recent drilling exploitation, this sandstone sequence still has potential because it is laterally and vertically extensive. The blanketing sandstone should be investigated to the north and south of the study area. Valley-fill sandstone trends are likely to be encountered that can be chased to the east and west. The Speechley Stray sandstone should also be investigated since it is laterally extensive. The Speechley Stray is interpreted as being deposited along a shoreline, so the north-south paloeshoreline trend should be followed. The Balltown B provides a lower probability of success since it is a sinuous channelized sandstone. If targeted, it should be investigated to the east and west which is assumed to be the general paleodip direction. The Fifth sandstone sequence one has the lowest 
probability of success since it is a sinuous channelized sandstone with limited thickness. The sandstone should be investigated along the observed north-south trend. 


\section{REFERENCES}

Asquith, G., and Krygowski, D., 2004, Basic Well Log Analysis: Tulsa, The American Association of Petroleum Geologist.

Boswell, R.M., and Donaldson, A.C., 1988, Depositonal Architecture of the Upper Devonian Catskill Delta Complex: Central Appalachian Basin, U.S.A.: Canadian Society of Petroleum Geologist Memoir 14, v. 1, p. 65-84.

Boswell, R.M., Thomas, B.W., Hussing, B.R., Murin, T.M., and Donaldson, A., 1988, Atlas of Upper Devonian/Lower Mississippian Sandstones in the Subsurface of West Virginia, in Roen, J.B., ed., West Virginia Geological and Economic Survey Report, p. 143.

Castle, J.W., 2000, Recognition of Facies, Bounding Surfaces, and Stratigraphic Patterns in Foreland-Ramp Successions: An Example from the Upper Devonian, Appalachian Basin, U.S.A. : Journal of Sedimentary Research, v. 70, p. 896-912.

Cecil, C.B., Brezinski, D.K., and DuLong, F., 2004, The Paleozoic record of changes in global climate and sea level: Central Appalachian Basin: U.S. Geological Survey Circular 1264, p. 77-133.

Cotter, E., and Driese, S., G, 1998, Incised-valley fills and other evidence of sea level fluctuations affecting deposition of the Catskill Formation, Appalachian foreland basin, Pennsylvania: Journal of Sedimentary Research, v. 68, p. 347-362.

Dalrymple, R.W., Zaitlin, B.A., and Boyd, R., 1992, Estuarine facies models; concpetual basis and stratigraphc implications: Journal of Sedimentary Research, v. 62, p. 1130-1146.

Dennsion, J.M., 1985, Catskill Delta Shallow Marine Strata: Geologic Society of America v. 201, p. 91-106.

Doveton, J.H., 1994, Geological Log Interpretation: Tulsa, Oklahoma, SEPM Short Course No. 29, 1-169 p.

Ettensohn, F.R., 1985, The Catskill Delta Complex and The Acadian Orogeny: a Model: Geologic Society of America Special Paper 201, p. 39-49.

Hamberg, L., and Nielsen, L.H., 2000, Shingled, sharp-based shoreface sandstones: depositional response to stepwise forced regression in a shallow basin, Upper Triassic Gassum Formation, Denmark: Geological Society, London, Special Publications, v. 172, p. 69-89.

Harper, J., Tatlock, D.B., and Wolfe, R.T., 1999, Petroleum-Shallow Oil and Natural Gas, in Shultz, C.H., ed., The geology of Pennsylvania: Pennsylvania Geological Survey and Pittsburgh Geological Society Special Publication 1,, p. 485-505.

Harper, J.A., and Laughrey, C.D., 1987, Geology of the oil and gas fields of southwestern Pennsylvania: Pennsylvania Geological Survey, in Report, M.R., ed., 4th series, p. 1-166.

—, 1989, Upper Devonian and Lower Mississippian stratigraphy and depositional systems, in Harper, J.A., ed., Geology in the Laurel Highlands of southwestern Pennsylvania: 54th Annual Field Conference of Pennsylvania Geologists, Guidebook: Johnstown, PA, p. 35-62. 
Holland, S.M., 2008, An Online Guide to Sequence Stratigraphy, Website: http://www.uga.edu/strata/sequence/index.html.

Hopkins, E.M., 1988, Sedimentology and Paleogeography of Upper Devonian Sandstones in North-Central Pennsylvania and Western New York: AAPG Bulletin, v. 72, p. 21-46.

Horsey, C.A., 1978, Stratigraphy of the Upper Devonian Speechley-Balltown interval in north-central West Virginia: Morgantown, WV, West Virginia University.

Johnson, A., G., 2008, Subsurface Stratigraphy of the Upper Devonian Brdford Group in the Greater Punxsutawney Area, Pennsylvania: Morgantown, WV, West Virginia University.

Laughrey, C.D., Billman, D.A., and Canich, M.R., 2004, Petroleum geology and geochemistry of the Council Run gas field, north central Pennsylvania: AAPG Bulletin, v. 88, p. 213-239.

McBride, P., 2004, Facies Analysis of the Devonian Gordon Stray Sandstone in West Virginia.: Morgantown, WV, West Virginia University.

McDaniel, B.A., 2006, Subsurface Stratigraphy and Depositional Controls on Late Devonian-Early Mississippian Sediments in Southwestern Pennsylvania: Morgantown, WV, West Virginia University.

Murin, T.M., and Donahue, J., 1984, Upper Devonian First Bradford formation of southwestern Pennsylvania: environment of deposition and factors affecting gas production: AAPG Bulletin, v. 68, p. 12.

Patchen, D.G., McDowell, R., and Avary, K.L., 1997, Adding Value to the Atlas of Major Appalachian Gas Plays, West Virginia Geological Survey and Appalachian Oil and Natural Gas Research Consortium: Morgantown, WV.

Peace, K., 1985, Detailed Deposystem Analysis of the Sandstones in the Upper Devonian-Lower Mississippian Acadian Clastic Wedge, Northern West Virginia: Morgantown, WV, West Virginia Uiversity.

Sevon, W.D., 1985, Nonmarine facies of the Middle and Late Devonian Catskill coastal alluvial plain: Geological Society of America, v. Special Paper 201, p. 79-90.

Smosna, R., and Bruner, K.R., 1997, Depositional Controls Over Porosity Development in Lithic Sandstones of the Appalachian Basin: Reducing Exploration Risk: AAPG Memoir 69, p. 249-265.

VanWagoner, J.C., Mitchum, R.M., Campion, K.M., and Rahmanian, V.D., 1990, Siliclastic Sequence Stratigraphy in Well Logs, Cores, and Outcrops: Concepts for High-Resolution Correlation of Time and Facies: Tulsa, OK, American Association of Petroleum Geologists.

Williams, H., and Hatcher, R., 1982, Suspect terrains and accretionary history of the Appalachian orogen: Geological Society of America, v. 10, p. 530-536.

Wilson, B.W., and Nanz, R.H., 1959, Sand Conditions as Indicated by the Self-Potential Log, EPR Memorandum Report Houston, TX, Shell Development Company, p. 25. 